\title{
AVALIAÇÃO DA QUALIDADE DE NÉCTARES COMUM E DIETÉTICO DE GOIABA DAS VARIEDADES PALUMA E PEDRO SATO
}

\author{
VIVIANE SOCCIO MONTEIRO \\ Engenheira de Alimentos
}

Orientador: Prof. Dr. JOÃO NUNES NOGUEIRA

Dissertação apresentada à Escola Superior de Agricultura "Luiz de Queiroz", para obtenção do título de Mestre em Ciências, Área de Concentração: Ciência

Tecnologia de Alimentos

PIRACICABA

Estado de São Paulo - Brasil

Outubro - 1999 
Dados Internacionais de Catalogação na Publicação (CIP) DIVISÃO DE BIBLIOTECA E DOCUMENTAÇÃO - Campus "Luiz de Queiroz"/USP

\section{Monteiro, Viviane Soccio}

Avaliaçăo da qualidade de néctares comum e dietético de goiba das variedades

Paluma e Pedro Sato / Viviane Soccio Monteiro. - Piracicaba, 1999.

$$
110 \mathrm{p} \text {. }
$$

Dissertação (mestrado) - Escola Superior de Agricultura Luiz de Queiroz, 1999. Bibliografia.

1. Análise química 2. Avaliação nutricional 3. Conservação de alimento por refrigeração 4. Fruta 5. Néctar de goiaba 6. Produto dietético 7. Tecnologia de bebida 8 . Vitamina $C 1$. Titulo

CDD 60.3 .63 
ERRATA

\begin{tabular}{|c|c|c|c|c|}
\hline Página & Parágrafo & Linha & Onde se lê: & Leia-se: \\
\hline 17 & $4^{\circ}$ & $4^{\underline{a}}$ & concentracão & concentração \\
\hline 18 & $3^{\circ}$ & $4^{\mathrm{a}}$ & degradadou-se & degradou-se \\
\hline 31 & $2^{\circ}$ & $1^{\underline{a}}$ & purê do & purê da \\
\hline 31 & $2^{\circ}$ & $2^{\mathrm{a}}$ & purê do & purê da \\
\hline 41 & $3^{\circ}$ & $2^{\mathrm{a}}$ & diferenstes & diferentes \\
\hline 42 & $1^{\circ}$ & $2^{\mathrm{a}}$ & a presentados & apresentados \\
\hline 42 & $3^{\circ}$ & $3^{\mathrm{a}}$ & $\begin{array}{l}\text { Lima et al. } \\
\text { (1988) }\end{array}$ & $\begin{array}{l}\text { Lima et al. } \\
\text { (1998) }\end{array}$ \\
\hline 42 & $3^{\circ}$ & $4^{\mathrm{a}}$ & frutos do Pedro & frutos da Pedro \\
\hline 46 & $3^{\circ}$ & $11^{a}$ & ácido ascóbico & Ácido ascórbico \\
\hline 67 & $1^{0}$ & $1^{\underline{a}}$ & abela & Tabela \\
\hline 75 & $1^{0}$ & $1^{\mathrm{a}}$ & latasdos & latas dos \\
\hline 81 & $1^{0}$ & $4^{\mathrm{a}}$ & perído & período \\
\hline
\end{tabular}

\begin{tabular}{cccc}
\hline Página & Figura & Onde se lê: & Leia-se: \\
\hline 55 & 10 & T3 & T4 \\
55 & 10 & $\mathrm{~T} 4$ & T3 \\
59 & 11 & $\mathrm{~T} 3$ & $\mathrm{~T} 4$ \\
59 & 11 & $\mathrm{~T} 4$ & $\mathrm{~T} 3$ \\
60 & 12 & $\mathrm{~T} 3$ & $\mathrm{~T} 4$ \\
60 & 12 & $\mathrm{~T} 4$ & $\mathrm{~T} 3$ \\
\hline
\end{tabular}




\section{UNIÃO}

...unamo-nos.

Só a união conseguirá fortalecer-nos para o exato cumprimento de nossas obrigações, com o serviço e a humildade por normas de ação.

(Bezerra de Menezes) 
Aos meus pais, Maria Cecilia e Wilson,

pelo amor, carinho e confiança e por me incentivarem a perseguir meus objetivos.

Ofereço

Aos meus irmãos, Gisela, Ricardo, Adriano e Ludmila, e familiares que mantiveram-se sempre ao meu lado.

Ao Renato, que me ajudou a manter o equilibrio, a força e ir em frente.

Dedico 


\section{AGRADECIMENTOS}

A Deus, por sempre estar presente, mostrando e iluminando o meu caminho;

Ao meu orientador, Prof. Dr João Nunes Nogueira, pelo apoio e orientação durante o desenvolvimento deste trabalho;

À Escola Superior de Agricultura "Luiz de Queiroz", em especial ao Departamento de Agroindústria, Alimentos e Nutrição, seus professores e funcionários, pelos ensinamentos e pelo auxílio na realização deste trabalho;

Ao Prof. Fernando J. Durigan e Renata Tostes da Unesp-Jaboticabal, pelo contato com o produtor de goiaba;

Ao Sr. Luis Antônio Fiorani, pela doação de matéria-prima necessária na elaboração deste trabalho;

Aos Profs. Drs. Carlos Tadeu dos S. Dias e Sônia M. S. Piedade, pela valiosa ajuda na realização das análises estatísticas;

Ao amigo Rudmar A. Cherubin e amigas, Juliana A. Galvão, Leila Spadoti, Luciana V. Saboya e Tamara Bertol, pelo carinho, amizade, incentivo e por sempre estarem prontos à ajudar no que fosse preciso;

Aos técnicos José Carlos e Ivani Aparecida Marcheto Moreno, pela amizade e auxílio prestado na parte prática;

Ao Prof. Jorge Horii pelo carinho e auxílio na resolução de questões referentes ao mestrado;

À Lucia Cristina C. N. Godoy, pelo apoio e incentivo;

Às bibliotecárias Beatriz H. Giongo e Midian Gustinelli, pela amizade e auxílio na parte de referências bibliográficas;

À equipe de análise sensorial, pela colaboração inestimável;

Ao Conselho Nacional de Desenvolvimento Científico e Tecnológico-CNPq, pelo apoio financeiro a realização deste trabalho;

A todos meus amigos e colegas em especial, em especial Kátia (Ipê), Ingrid, Cléo, Roberta, Michele, Mônica, Renata Dória, Andréia K., Célia R. Zanin, Margarida (Bégs) e Ana Cláudia Lira.

Aos queridos familiares e amigos, pelo carinho, incentivo e paciência, em especial, aos avós Ester e Urbano Monteiro, Esmeralda e Braulio Socio; Luama; João e Tereza Machado; Andréa (Bau); Claudinéa; Juquete; Antônio Carlos e Anna M. Henrique. 


\section{SUMÁRIO}

\section{Página}

RESUMO

SUMMARY

1 INTRODUÇÃO

2 REVISÃO BIBLIOGRÁFICA 3

2.1 Origem, Consumo e Valor nutricional da Goiaba 4

$\begin{array}{ll}2.2 \text { Variedades } & 6\end{array}$

2.3 Néctar $\quad 9$

2.4 Vitamina C 11

2.5 Aditivos 13

2.5.1 Acidulantes $\quad 14$

2.5.1.1 Ácido Cítrico $\quad 15$

$\begin{array}{ll}\text { 2.5.2 Conservantes } & 15\end{array}$

2.5.2.1 Ácido Sórbico e Derivados 16

$\begin{array}{ll}\text { 2.5.3 Aditivos Nutricionais } & 18\end{array}$

$\begin{array}{ll}\text { 2.5.3.1 Ácido Ascórbico } & 18\end{array}$

$\begin{array}{ll}2.6 \text { Cor e Aroma } & 19\end{array}$

$\begin{array}{ll}2.7 \text { Alimentos Dietéticos } & 20\end{array}$

$\begin{array}{ll}2.7 .1 \text { Sorbitol } & 22\end{array}$

2.8 Alterações durante Armazenamento $\quad 24$ 
$\begin{array}{ll}3.1 \text { Matéria-prima } & 27\end{array}$

$\begin{array}{ll}3.2 \text { Caracterização da Matéria-prima } & 27\end{array}$

$\begin{array}{ll}\text { 3.2.1 Análises fisicas } & 27\end{array}$

$\begin{array}{ll}\text { a) Rendimento em purê } & 27\end{array}$

b)Textura 28

$\begin{array}{ll}\text { 3.2.2 Análises quimicas } & 28\end{array}$

a)Ácido ascórbico 28

b) Ácidez total titulável $\quad 28$

$\begin{array}{ll}\text { c) } \mathrm{pH} & 29\end{array}$

d) Sólidos solúveis totais $\quad 29$

$\begin{array}{ll}\text { 3.3 Processamento } & 29\end{array}$

3.3.1. Elaboração de néctares 29

3.3.1.1 Despolpamento $\quad 29$

3.3.1.2 Formulação dos néctares $\quad 29$

A) Para obtenção de néctares comuns (com sacarose) 29

B) Para a obtenção de néctares dietéticos (com sorbitol) 33

3.3.1.3 Pasteurização $\quad 35$

3.3.1.4 Acondicionamento $\quad 35$

3.3.1.5 Recravação $\quad 35$

3.3.1.6 Inversão $\quad 35$

3.3.1.7 Resfriamento $\quad 35$

3.3.1.8 Armazenamento 36 
a) Vácuo 36

b) Peso bruto 36

c) Peso líquido 36

3.4.3 Análise sensorial 37

3.4.3 Análises Estatísticas dos Resultados 37

$\begin{array}{ll}\text { a) Matéria-prima } & 37\end{array}$

b) Néctares comuns e dietéticos

4 RESULTADOSE DISCUSSÃO 40

4.1 Caracterização da matéria-prima $\quad 40$

4.1.1 Análises físicas $\quad 40$

4.1.2 Análises químicas $\quad 42$

4.2 Análises químicas dos néctares, comuns e dietéticos, das variedades
Paluma e Pedro Sato

4.3 Análises sensoriais dos néctares comuns e dietéticos $\quad 75$

5 CONCLUSÕES

$\begin{array}{ll}\text { ANEXOS } & 84\end{array}$

REFERÊNCIAS BIBLIOGRÁFICAS 98 


\title{
AVALIAÇÃO DA QUALIDADE DE NÉCTARES COMUM E DIETÉTICO DE GOIABA DAS VARIEDADES PALUMA E PEDRO SATO
}

\author{
Autora: Viviane Soccio Monteiro \\ Orientador: Prof. Dr. João Nunes Nogueira
}

\section{RESUMO}

Foram processados néctares de goiaba, das variedades Paluma e Pedro Sato, nas formas comum e dietética. Aplicou-se em cada tipo de néctar diferentes tratamentos (armazenamento refrigerado e à temperatura ambiente, adição de sorbato de potássio e ácido ascórbico) com o objetivo de avaliar as variedades e qualidade dos néctares obtidos. A matéria-prima foi avaliada fisicamente em relação à textura e rendimento, e quimicamente em termos de acidez total titulável, $\mathrm{pH}$, sólidos solúveis totais e ácido ascórbico. As amostras dos néctares, comuns e dietéticos, das duas variedades, foram submetidas às análises físicas de vácuo, peso bruto, e peso líquido; às análises quimicas de acidez total titulável, $\mathrm{pH}$, ácido ascórbico e sólidos solúveis totais; e avaliados também sensorialmente quanto ao sabor, à consistência, e à cor. Concluiu-se que o melhor tratamento foi o armazenado sob refrigeração, pois ao final de 180 dias os néctares apresentavam um teor de ácido ascórbico de $30 \mathrm{mg} 100 \mathrm{~g}^{-1}$, que é o equivalente a metade do teor diário recomendado para o organismo humano adulto. As duas variedades de goiaba, Paluma e Pedro Sato, foram consideradas adequadas para o processamento de néctar, uma vez que resultaram em produtos de boa qualidade. $O$ tratamento que teve adição de ácido ascórbico foi eficiente para revitaminação, porém não teve boa aceitação quanto à cor e sabor na avaliação sensorial. Tanto, os néctares dietéticos, como os comuns, receberam boa avaliação, o que indica o sorbitol como um edulcorante adequado para o processamento de néctar dietético. 


\title{
QUALITY EVALUATION OF REGULAR AND LOW SUGAR GUAVA NECTARS FROM PALUMA AND PEDRO SATO VARIETIES
}

\author{
Author: Viviane Soccio Monteiro \\ Adviser: Prof. Dr. João Nunes Nogueira
}

\section{SUMMARY}

Regular and low sugar nectars from Paluma and Pedro Sato, guava varieties, were processed. Different treatments were applied to each kind of nectar (refrigerated and room temperature storage; potassium sorbate and ascorbic acid addition) in order to evaluate the varieties and the quality of the nectar obtained. The raw material was physically evaluated in relation to texture and yield, and chemically in terms of titratable acidity, pH, total soluble solids and ascorbic acid. The nectar samples, were submitted to physical determinations for vacuum, gross weight and net weight; to chemical analysis for titratable acidity, $\mathrm{pH}$, ascorbic acid and soluble solids, and to sensory evaluation for color, consistency and flavor. It was concluded that the best treatment was the refrigerated storage as, by the end of 180 days, the two kinds of nectar $30 \mathrm{mg}$ $100 \mathrm{~g}^{-1}$, which is equivalent to half of the daily amount recommended to the adult human organism. The two guava varieties, Paluma and Pedro Sato, were found to be suitable for nectar processing, based on the good quality of the final product obtained. The treatment in which ascorbic acid was added restored the vitamin losses however this samples did not receive good evaluation for color and taste. Both the regular and low sugar nectars presented a good quality, which indicates that sorbitol is a suitable sweetening agent for processing of low sugar nectar. 


\section{INTRODUÇÃO}

Néctar é uma bebida pronta para ser consumida, obtida da mistura de polpa da fruta, água, adoçante e ácido orgânico em quantidades que tornem $\circ$ produto agradável aos consumidores.

Nos últimos anos, o consumo de bebidas prontas, à base de frutas, tem aumentado muito no Brasil e no mundo, pois os consumidores querem cada vez menos preparar sucos em casa. Por outro lado, não abrem mão dessas bebidas por sua riqueza em nutrientes e seus sabores atrativos.

A goiaba é uma fruta atrativa, possui sabor agradável e é bem aceita no mundo todo. Apresenta ótimas qualidades nutritivas, sendo fonte de micronutrientes, vitaminas e minerais, e de fibras solúveis e insolúveis, com a vantagem de ter baixo valor calórico e reduzido teor de lipídeos. Sendo assim, o consumo da fruta ao natural como o de seus produtos deve aumentar, pois os consumidores estão cada vez mais preocupados com a qualidade nutricional dos alimentos que consomem.

Como existem muitas variedades de goiabas, torna-se necessário pesquisar quais as que mais se adequam ao processamento de néctar, em termos de cor, sabor, acidez, sólidos solúveis, vitamina $\mathrm{C}$ e quanto ao rendimento, para que as indústrias possam obter produtos de boa qualidade. As frutas das variedades Paluma e Pedro Sato, apresentam características que as indicam como sendo de boa qualidade para o processamento de néctar.

Muitas pessoas não podem consumir alimentos com açúcar como as portadoras de diabetes mellitus, e por esta razão as indústrias estão desenvolvendo produtos alimentícios (geléias, sorvetes, bebidas, derivados de leite, chocolate e outros) adoçados com substitutos do açúcar. Entretanto, esses substitutos precisam ser compativeis com os produtos quanto ao processamento e quanto ao sabor. 
Este experimento foi desenvolvido com o objetivo de avaliar a qualidade de néctares de goiaba, adoçados com sacarose ou com sorbitol, das variedades Paluma e Pedro Sato, visando a obtenção de produtos de alta qualidade. 


\section{REVISÃO BIBLIOGRÁFICA}

O valor nutritivo da goiaba e suas excelentes qualidades organolépticas conferiram-Ihe importância na alimentação humana, promovendo sua industrialização em larga escala. Além de ser consumida na forma de fruta fresca, pode ser industrializada sob as mais variadas formas: polpa de goiaba, goiabada, geléia, fruta em calda, suco, néctar e sorvete, atingindo importância econômica e social bastante significativa em muitos paises do mundo e em vários estados do Brasil (Fioravanço et al., 1995).

No Brasil, a goiaba é muito utilizada na indústria e seus produtos têm excelente aceitação no mercado. A qualidade das frutas é devida a componentes físicos e quimicos próprios, os quais Ihe conferem características típicas quanto a aparência, composição química, sabor, aroma e textura (Carvalho, 1994).

A transformação de frutas em sucos, polpas e outros produtos foi desenvolvida com o propósito de servir de suplementação de frutas frescas no mercado. Muitas frutas são colhidas para este fim e as práticas culturais e de colheitas devem ser efetuadas com base nos requisitos de qualidade, físicos, físico-químicos e sensoriais (Montgomery, 1988).

O consumo de sucos prontos mais que dobrou nos últimos quatro anos. A busca de uma vida mais saudável, começando pela alimentação, aliada ao clima tropical, fez o brasileiro bater um recorde no consumo destes produtos. Em 1998 foram consumidos cerca de 66 milhões de litros, 8 milhões a mais do que em 1997 (Valentini, 1999). Hoje menos pessoas querem perder tempo preparando o suco em casa com a polpa da fruta congelada ou concentrada. Pensando nestes consumidores, as empresas também estão processando bebidas com frutas que tenham sabores mais exóticos. 
Néctar é uma bebida pronta para ser consumida, obtida basicamente pela mistura de polpa de fruta, água, adoçante e ácido orgânico. Sabe-se que os néctares de frutas tropicais são bem aceitos no mundo todo. Observa-se um mercado crescente, tanto interno como extemo, para o consumo dos mais diferentes produtos industrializados da goiaba, destacando-se: polpa, fruta em calda, pastas, geléias, doces e sucos, sendo o segmento dos sucos o que tem apresentado o maior crescimento nos últimos anos. Cabe registrar que na industrialização da fruta a exigência recai sobre as frutas de polpa avermelhada e com brix maior que 8,5 (Zambão \& Bellintani Neto, 1998).

A matéria-prima é um dos fatores mais importantes para a obtenção de néctar e também de outros produtos de origem vegetal de boa qualidade: frutas de variedades selecionadas próprias para o processamento.

A utilização de variedades selecionadas e adequadas para a industrialização, aliada ao emprego de tecnologia simples e eficiente tomará possivel a obtenção de néctares de goiaba de boa qualidade. Esta é uma exigência atual do mercado, que se toma cada vez mais competitivo dentro e fora do pais.

Muitas indústrias de alimentos estão utilizando edulcorantes em formulações de produtos destinados a consumidores que necessitam de restrição calórica em suas dietas, bem como para aqueles portadores de diabetes. Os edulcorantes também ajudam na diminuição de incidência de cárie dental e substituem o açúcar quando este não está disponivel no mercado (Nabors \& Gelardi,1991).

\subsection{Origem, Consumo e Valor Nutricional da Goiaba}

A goiabeira, Psidium guajava L., é originária da América Tropical, e atualmente encontra-se distribuida por todas as regiões tropicais e subtropicais do mundo, produzindo frutos bastante apreciados por causa de seu sabor e aroma, da elevada digestibilidade, da riqueza em vitaminas $A, B$ e $C$, em fibras, proteinas e sais minerais (Fioravanço et al., 1995).

Segundo Zambão \& Bellintani Neto (1998), a hipótese mais aceita é que a goiabeira teria como centro de origem a região entre Brasil e Peru, de onde se difundiu para todas as baixas regiões tropicais e subtropicais do mundo. Essa grande e rápida difusão da planta ocorreu, provavelmente, por causa da sua facilidade em multiplicar- 
se por sementes, que são muito numerosas nos frutos, e por causa da rusticidade da planta, que se desenvolve sem dificuldades em solos de baixa fertilidade e com baixa retenção de umidade.

Wilson et al. (1982) e Pereira \& Martinez Júnior (1986) verificaram que certas variedades apresentam cerca de 600 a 700 mg de ácido ascórbico por 100g de polpa, isto é, dez vezes mais do que qualquer variedade de laranja conhecida, sendo também rica nas vitaminas $\mathrm{A}$ e $\mathrm{B}$ e fonte regular de ferro, cálcio e fósforo.

Segundo Aroeira (1960), 100g de polpa de goiaba contêm $1 \mathrm{~g}$ de proteina; $0,6 \mathrm{~g}$ de gordura; 17g de glicídios; 60 a 100mg de ácido ascórbico; 40 a 55 microgramas de vitamina B1; 88 microgramas de riboflavina; 200 unidades internacionais de vitamina $A$ e 78 calorias. Além das qualidades citadas, a goiaba é fonte regular de ferro, cálcio e fósforo.

Segundo Zambão \& Bellintani Neto (1998), no caso específico do Brasil, não se dispõe de um levantamento completo da produção de goiabas, sendo estimada a partir do volume de matéria-prima industrializada, somada às quantidades comercializadas nos entrepostos dos grandes centros comerciais. Estima-se uma produção nacional da ordem de 100 mil toneladas de frutos por ano, sendo que aproximadamente $70 \%$ dessa produção concentra-se no Estado de São Paulo. Outros estados importantes na produção de goiaba são: Minas Gerais, Pernambuco, Rio de Janeiro, Rio Grande do Sul e Ceará.

No estado de São Paulo as produções concentram-se nas regiões de Monte Alto/Taquaritinga, CampinasNalinhos e Mirandópolis. A produção de goiaba para processamento industrial, neste estado, é concentrada na Divisão Regional Agrícola (DIRA) de Ribeirão Preto, destacando-se os municipios de Itápolis, Monte Alto, Taquaritinga e circunvizinhos. Segundo o Instituto de Economia Agrícola, existem neste estado cerca de 1.275 .000 plantas com produção destinada à mesa; 90 mil delas são pés novos. Outros levantamentos indicam que, no Brasil, são 7.800 hectares de área plantada com a cultura da goiabeira (Zambão \& Bellintani Neto,1998; Pereira \& Martinez Júnior, 1986).

Dentre os maiores produtores mundiais de goiaba destacam-se a Índia, o Paquistão, o Brasil, o México, o Egito, a Venezuela, a África do Sul, os EUA, a Jamaica, o Quênia e a Austrália (Zambão \& Bellintani Neto,1998). 
Observou-se, em relação à exportação de suco de goiaba do Brasil, uma certa estabilidade ficando, entre 600 e 800 toneladas, a partir de 1989. A taxa de crescimento anual calculada foi de $31,84 \%$. Entre os principais clientes estão os Estados Unidos, que importam quase $90 \%$ de nossa produção, seguido pelos Países Baixos. Com a criação do MERCOSUL observou-se o crescimento relativo das exportações de produtos de goiaba para os países signatários do acordo (Vegro \& Miranda, 1994).

\subsection{Variedades}

É importante salientar que variedades selecionadas da fruta podem apresentar características satisfatórias ao plantio: ser resistentes a doenças, atingir a época de maturação no tempo adequado; porém essa mesma variedade pode não ser adequada ao processamento. De qualquer modo, a utilização de variedades selecionadas irá influenciar na qualidade final dos produtos obtidos (Fonseca \& Nogueira, 1984).

No Brasil, o plantio de goiabeiras ocorre basicamente por propagação de sementes (polinização cruzada), gerando frutas heterogêneas. Em certas regiões produtoras, no entanto, a propagação espontânea vem sendo substituida por plantas propagadas vegetativamente, onde a fruta de melhor qualidade, vem sendo bastante valorizada pela indústria e difundida para o consumo ao natural (Fioravanço et al., 1995).

A avaliação qualitativa da fruta juntamente com os dados de produção da planta, sua resistência a moléstias e pragas, porte baixo e aberto, permite identificar e selecionar as melhores variedades, altamente produtivas e que atendam às características próprias para o consumo ao natural ou para a industrialização (Fioravanço et al., 1995).

Quanto às características das frutas, diversas variáveis devem ser consideradas com relação a escolha de uma variedade, uma vez que existem inúmeras opções para a destinação da produção, sendo que cada finalidade tem preferências específicas.

Lemos et al. (1995) indicam que as características físicas, como o formato, a textura, o rendimento da polpa, a coloração da casca e da polpa; as características 
químicas, como: os teores de açúcares, de ácidos e compostos voláteis, variam entre as variedades e, dentre estas, com as condições climáticas dos locais de cultivo, com a adubação e com os tratos dispensados à cultura.

Segundo Fioravanço et al. (1995), as principais variedades de goiabas cutivadas no Brasil para a industrialização são: Comum, Guanabara, IAC - 4, Rica, Paluma, Brune Vermelha, Riverside Vermelha e Pirassununga Vermelha.

Para o processamento industrial, as goiabas preferidas são as que apresentam: polpa de coloração rosada a vermelha, alta acidez, alta porcentagem de sólidos solúveis totais, altos teores de pectina (Kavati, 1997), pH em tomo de 3,4 e formato arredondado (Fioravanço et al., 1995).

As goiabas de polpa vermelha, apesar de serem genericamente consideradas de cor vermelha, na verdade apresentam coloração em vários tons de rosa. De um modo geral, as frutas de variedades com polpa vermelha apresentam sabor e aroma mais intensos (Kavati, 1997).

Paluma, é uma variedade desenvolvida pela Faculdade de Ciências Agrárias e Veterinárias de Jaboticabal; ela é o resultado de uma seleção feita em lotes de sementes das variedades Rub e Supreme. São plantas muitos produtivas, vigorosas, de crescimento lateral, bastante tolerantes à ferrugem. As frutas são grandes, podendo atingir mais de $500 \mathrm{~g}$ quando bem raleadas e em plantas jovens. São piriformes, com a casca lisa, de coloração amarela na maturação, apresentando polpa espessa, de cor rosada intensa, gosto ácido e com forte aroma. Têm características excepcionais para o processamento industrial. $\dot{E}$ seguramente a variedade mais plantada no Brasil nos últimos anos, principalmente pela facilidade com que se obtêm mudas do enraizamento por estacas (Kavati, 1997). Avaliando as características químicas em goiabas Paluma recém colhidas, porém maduras, Darezzo \& Durigan (1995) obtiveram valores médios de $9,3^{\circ} \mathrm{Brix}, 0,470 \mathrm{~g}$ ácido cítrico $100 \mathrm{~g}^{-1}$ de polpa e $168 \mathrm{mg}$ ácido ascórbico $100 \mathrm{~g}^{-1}$ de polpa de fruta.

De acordo com Pereira (1984), as variedades Rica e Paluma apresentam ótimas características agronômicas. As frutas da variedade Rica são adequadas para a elaboração de frutas em calda e de doce em massa; os da variedade Paluma para doce em massa e para consumo ao natural.

Pedro Sato é uma variedade que surgiu a partir da seleção de pés francos, provavelmente originários da Ogawa $N^{\circ} 1$ Vermelha, Rio de Janeiro. São plantas 
vigorosas, com folhas elipticas grandes e bastante coriáceas; produtivas, de crescimento lateral, formando longos ramos arqueados. As frutas são grandes, têm 300 a 400g de peso, em média, com casca bem rugosa, formato oblongo; polpa rosada, espessa e firme, e a cavidade central cheia e com poucas sementes. E a variedade de casca rugosa mais difundido no Estado de São Paulo atualmente (Pereira, 1995).

Lima et al. (1998), estudando as frutas da variedade Pedro Sato, relataram que as mesmas podem apresentar de 8,9 a $10,85^{\circ} \mathrm{Brix}, 0,36$ a $0,58 \mathrm{~g}$ de ácido cítrico $100 \mathrm{~g}^{-1}$ de polpa e 94,26 a $137,19 \mathrm{mg} 100 \mathrm{~g}^{-1}$ de vitamina $\mathrm{C}$.

Esteves et al. (1984a), caracterizaram variedades de goiabeiras na maturação. Fizeram determinações físicas e químicas em frutas de várias variedades e concluíram que as variedades Brune Vermelha, IAC-4 e São José Piriforme apresentaram melhores caracteristicas para a industrialização (tamanho médio, forma arredondada, polpa grossa, acidez de $0,6 \%$ a 1,0\% de ácido cítrico e com rendimento em torno de $70 \%)$. Os mesmos autores estudaram também a vitamina $\mathrm{C}$ em frutas de várias variedades e concluiram que o teor da vitamina aumentou até a maturidade das goiabas, decrescendo ligeiramente na fase de senescência. Dentre as frutas analisadas, as frutas maduras da variedade IAC-4 apresentaram os maiores teores de vitamina $\mathrm{C}\left(371,90 \mathrm{mg} 100 \mathrm{~g}^{-1}\right)$.

Estudando a Brune Vermelha, Pereira \& Martinez JR (1986), Medina (1978), Esteves et al. (1984a e b) e Passos et al. (1979) relataram que as frutas dessa variedade apresenta teor de umidade de $85 \%$, sólidos solúveis totais variando de 6,88 a $9,00 \%$ e acidez titulável de $0,6 \%$ de ácido cítrico. O teor de vitamina $C$ variou de 18 a $215 \mathrm{mg}$ de ácido ascórbico $100 \mathrm{~g}^{-1}$ da fruta.

Marteleto (1980), verificou que as goiabas da variedade Riverside Vermelha apresentam acidez titulável de $0,83 \%$ de ácido citrico, com $7,9 \%$ de sólidos solúveis totais e teor de vitamina $\mathrm{C}$ em tomo de $147 \mathrm{mg}$ de ácido ascórbico $100 \mathrm{~g}^{-1}$ da fruta.

Diwakar et al. (1993) avaliando as frutas de três variedades de goiabeira, encontraram teores mais elevados de sólidos solúveis totais nas frutas da variedade Allahabad Safeda, $(9,65 \%)$, seguida das variedades Sarder $(8,85 \%)$ e Red Fleshed (8,45\%). Para estas variedades a acidez variou de $0,54 \%$ a $0,49 \%$ de ácido cítrico, respectivamente. A variedade Allahabad Safeda apresentou-se como a mais rica em

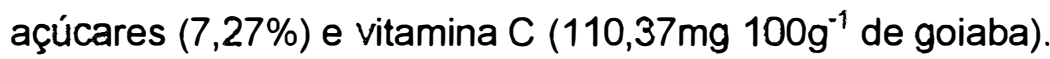


Pinheiro et al. (1984), realizaram estudos comparativos entre variedades e concluiram que a variedade Pirassununga Vermelha produz frutos com as melhores características para a industrialização. Com esta variedade foram processados doce em massa, geléia e goiaba em calda, obtendo-se resultado final satisfatório.

\subsection{Néctar}

Segundo Lima (1998), néctar é o produto não fermentado, não gaseificado obtido da parte comestivel da fruta (polpa e suco), diluído com água potável e com adição de açúcar e ácido orgânico, destinado ao consumo direto. O açúcar e a água são adicionados à polpa, em quantidades adequadas à concentração e ao sabor desejados.

O néctar de fruta contém entre $25 \%$ e $50 \%$ de suco e/ou polpa, dependendo da fruta. Na Comunidade Européia, por exemplo, os néctares contém um mínimo de $50 \%$ de fruta (no caso de laranja, abacaxi e maçã); 40\% de damasco; 35\% de manga e $25 \%$ de maracujá e goiaba. Os néctares encontrados no mercado são feitos com uma ou com a mistura de duas ou mais frutas (Gonzaga Neto, 1994).

O suco diluído com água e/ou xarope não pode ser oficialmente denominado suco, mas deve ser chamado de néctar, coquetel, bebida ou "juice drink", dependendo da percentagem da fruta que entra na sua formulação. No néctar, os ingredientes de frutas podem ser o purê, o suco simples ou concentrado (cerca de $40 \%$ do produto acabado). Os ingredientes opcionais são: suco de limão, ácido cítrico, maléico ou fumárico (acidificantes) e ácido ascórbico (antioxidante) (Kato \& De Martin, 1978).

No Havaí, o néctar comercial produzido em grande escala contém cerca de $20 \%$ de polpa de goiaba e $80 \%$ de xarope, e o produto final apresenta cerca de $11 \%$ de sólidos solúveis e pH 3,3 a 3,5 (Lynch et al., 1959).

Destinados a consumidores cada dia mais exigentes quanto ao sabor, ao odor, à cor e quanto ao valor nutricional, os produtos de frutas têm seu sucesso fundamentado no desenvolvimento de processos que melhor preservam suas características naturais e no emprego de embalagens que thes proporcionem a vida útil desejada, mantendo, nesse periodo, a qualidade do produto em niveis satisfatórios (Alves \& Garcia, 1993). 
A conservação de sucos de frutas é basicamente determinada pelas condições que preservam as suas qualidades organolépticas (aroma, cor, sabor, consistência, estabilidade da turbidez, distribuição das partículas), e que previnem o desenvolvimento de microrganismos deterioradores e a ocorrência de reações quimicas ou enzimicas indesejáveis (Ubold Eiroa, 1989).

Segundo Alves \& Garcia (1993), a conservação dos sucos de frutas é determinada, primeiramente, pela prevenção do desenvolvimento de microrganismos deterioradores e pela inibição da ação de enzimas naturais, o que é obtido por meio do tratamento térmico a que é submetido o produto e/ou pelo uso de conservantes químicos ou comercialização sob refrigeração/congelamento.

Em alimentos ácidos ( $\mathrm{pH}$ igual ou inferior a 4,6), um tratamento a $85^{\circ}-90^{\circ} \mathrm{C}$ durante 15 a 30 segundos é suficiente para se obter uma esterilidade comercial. Isso porque os microrganismos que podem deteriorar sucos de frutas, são leveduras, mofos e bactérias láticas, com pouca resistência térmica. A temperatura atingida é também suficiente para inativar enzimas que podem ocasionar transformações indesejáveis em certos produtos (Gava, 1985).

Segundo De Martin (1969), o néctar deve ser submetido às temperaturas de 82 a $88^{\circ} \mathrm{C}$ por 60 segundos, colocado em latas, que são a seguir recravadas e finalmente submetidas a um resfriamento rápido. Alguns fabricantes e consumidores acreditam que a adição de uma pequena porcentagem de ácido citrico melhora o sabor natural da fruta.

O sistema mais comumente empregado para conservação do néctar é a pasteurização e com enchimento a quente ("hot fill") a $90^{\circ} \mathrm{C}$, em latas ou em garrafas. Existe também a possibilidade de se utilizar o processo pasteurizador rotativo ("spin cooker"), para pasteurização do néctar enlatado à temperatura ambiente e fechado a vácuo. Sendo a polpa de goiaba de natureza ácida ( $\mathrm{pH}$ natural próximo de 4,0), possibilita perfeitamente o uso da técnica de enchimento a quente, conhecido internacionalmente como processo "hot-fill" (ou enchimento a quente).

De acordo com Kato \& De Martin (1978), polpa de goiaba é o produto obtido da parte comestivel da fruta, podendo ser triturada e refinada, sendo, neste caso, também denominada de purê, a qual é em seguida, preservada por um processo físico ou químico adequado. É utilizada quase sempre como matéria-prima para processamento 
de outros produtos, tais como, néctar, suco, geléia, sorvete, ingredientes de produtos de lacticínios e doces de pasta de goiaba em geral.

A seção de Frutas e Doces do ITAL obteve em análises químicas de

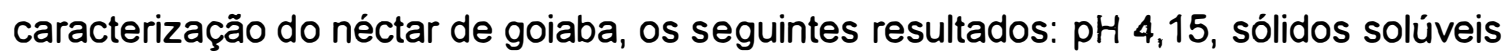
$16,0 \%$, acidez total titulável $0,089 \%$ e ácido ascórbico $14,7 \mathrm{mg} / 100 \mathrm{~g}$ (Kato \& De Martin, 1978).

\subsection{Vitamina C}

Existe uma tendência mundial em relação ao mercado consumidor de frutas e produtos de frutas. É cada vez maior a demanda por esses produtos devido ao seu valor nutricional (principalmente as vitaminas $\mathrm{A}$ e $\mathrm{C}$ ) e das fibras, componentes esses que vêm sendo freqüentemente associados à remoção de radicais livres e à prevenção de diversas doenças como câncer, distúrbios coronários e excesso de colesterol.

A vitamina C (ácido ascóbico e dehidroascórbico), conhecida como vitamina anti-escorbuto, desempenha várias funções no metabolismo. Favorece o aumento da resistência orgânica e a formação do colágeno (substância protéica que une as células e sustenta o tecido conjuntivo), é ativador de crescimento, interfere no metabolismo do ferro, da glicose (Franco,1992) e na saúde dos dentes e gengivas (Winton \& Winton, 1958).

A principal causa da degradação da vitamina C é a oxidação, aeróbica ou anaeróbica, ambas levando à formação de furaldeídos, compostos que se polimerizam facilmente, com formação de pigmentos escuros. É também destruída pela ação da luz.

Em geral, a estabilidade da vitamina $C$ aumenta com o abaixamento da temperatura e a maior perda ocorre durante o aquecimento de alimentos. Existem casos de perda da vitamina durante o congelamento, ou armazenamento de alimentos em baixas temperaturas. Também há perdas de vitamina $C$ por lixiviação em alimentos, principalmente a operação quando é feita com aquecimento (Bobbio \& Bobbio, 1989). 
A vitamina $\mathrm{C}$, também conhecida como ácido L-ascórbico, está distribuida na natureza predominantemente no reino vegetal e principalmente em frutas e hortaliças. No entanto, é umas das vitaminas que mais se perde durante o processamento.

Para se avaliar a perda da qualidade de alimentos durante o seu armazenamento monitora-se a diminuição da concentracão de algum componente químico, identificado como um dos fatores de qualidade do alimento. A quantidade de vitamina $\mathrm{C}$ em sucos de frutas é um fator de qualidade. $\mathrm{O}$ ácido ascórico é importante para o metabolismo normal de células, tecidos e orgãos, nas funções do sistema imunológico e cicatrização de ferimentos. Nos alimentos, age como agente redutor, antioxidante e sequestrador de ions metálicos. No trato intestinal, reduz o ion férrico da dieta a ferroso, aumentando sua absorção e diminui a sintese de nitrosaminas, que são consideradas substâncias carcinogênicas (Block \& Langseth, 1994).

De acordo com Badifu (1991) e Vieira et al.,(1982), a quantidade do ácido ascórbico em produtos naturais é influenciada por uma série de fatores, tais como 0 tipo de solo, a forma do cultivo, as condições climáticas, procedimentos agrícolas para a colheita, armazenamento e estocagem. A perda do ácido ascórbico inicia-se logo após a colheita das frutas ou hortaliças, principalmente sob o efeito da ação enzimática. Portanto, é de se esperar que o teor vitamínico não seja constante durante o processamento de alimentos industrializados, ocorrendo degradação parcial do ácido ascórbico até se chegar ao produto final.

Segundo Cereda \& Sampaio (1970), os sucos de frutas são preferencialmente consumidos por causa da sua riqueza em vitamina $C$. Sabe-se que além de ser termolábil, ela é facilmente oxidada, tendo seus niveis diminuídos pela má conservação.

Fonseca \& Nogueira (1968) preocupados em saber qual a influência da industrialização na preservação de vitaminas em frutas, analisaram inúmeros produtos industrializados de goiaba, dentre eles néctares de duas fábricas, nos quais foram

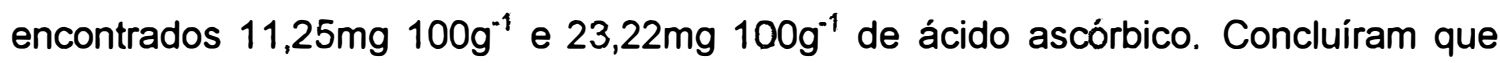
estes conteúdos poderiam ser maiores se os fabricantes utilizassem matéria-prima de melhor qualidade e empregando uma técnica mais adequada de processamento.

O aumento da velocidade de oxidação do ácido ascórbico está relacionado com o tratamento térmico ao qual a fruta ou produto foi submetido. Muitos trabalhos enfatizam a necessidade de se evitar altas temperaturas, utilizar processo de 
enchimento com o mínimo de aeração, evitar exposição à luz e a contaminantes metálicos para se obter um produto com o maior valor nutricional possivel (Counsell \& Hornig, 1981). Alterações sensoriais e reações de escurecimento devidas à degradação do ácido ascórbico têm sido freqüentemente detectadas em produtos à base de frutas, durante o seu armazenamento (Counsell \& Hornig, 1981; SanchezNieva, 1955; Jagtiani, et al., 1988).

Vários fatores são importantes na estabilidade do ácido ascórbico presente nos sucos de frutas; dentre os fatores negativos, tem-se a presença de enzimas oxidativas, a pasteurização, a luz, a contaminacão com metais pesados, bem como a presença de dióxido de enxofre. Nesse sentido, a escolha de equipamentos apropriados para o processamento, bem como a adição de determinadas quantidades de ácido ascórbico aos alimentos apresenta-se como de relevante importåncia. Equipamentos revestidos ou construídos em aço inoxidável, alumínio e plástico são mais adequados ao processamento dos alimentos do que aqueles construídos ou revestidos de cobre, ferro e níquel. Por outro lado, a desaeracão e o tratamento com gases inertes também são práticas recomendáveis, que contribuem para a manutenção dos níveis de ácido ascórbico dos alimentos (Lourenço).

Cereda et al. (1982), estudando suco de maracujá pasteurizado e congelado, encontrou uma perda de ácido ascórbico de $26 \%$ após o processamento e armazenamento por 21 dias. O valor médio para o suco congelado $\left(42,73 \mathrm{mg}^{100 \mathrm{~g}^{-1}}\right)$

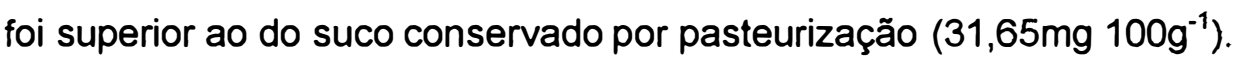

\subsection{Aditivos}

Além das substâncias e elementos químicos presentes de modo natural nas matérias-primas alimentícias, outros produtos poderão ser incorporados às mesmas, direta ou indiretamente, durante o processamento, acondicionamento e transporte dos alimentos. São os chamados aditivos, de composição química conhecida e intencionalmente adicionados em quantidades pequenas e controladas, com a finalidade de auxiliar o processo tecnológico, melhorar a qualidade organoléptica e aumentar o tempo de conservação dos produtos (Pavanello, 1990). 
Esses aditivos compreendem, entre outros, agentes inibidores de crescimento microbiano, antioxidantes, acidulantes, aromatizantes, corantes, estabilizantes e emulsificantes; geralmente são citados nos rótulos das embalagens dos alimentos.

A adição de produtos químicos aos alimentos não é um processo modemo de conservação. O homem pré-histórico, com a descoberta do fogo, criou o processo de defumação, usado até hoje na preservação de certos alimentos. Depois ele aprendeu a utilizar sal na conservação de carnes, os condimentos para melhorar a palatabilidade de certos alimentos e a realizar fermentações de produtos vegetais e animais (Volpi, 1985).

Com o avanço tecnológico no processamento de alimentos, aumentou a variedade e o uso de aditivos. Hoje, existem mais de 2500 tipos diferentes de aditivos que podem ser intencionalmente adicionados aos alimentos para produzir um efeito desejado (Branen, 1990).

Brasil (1997) considera como aditivo a substância intencionalmente adicionada ao alimento, com a finalidade de conservar, intensificar ou modificar suas propriedades, ou exercer qualquer ação exigida para uma boa tecnologia de fabricação do alimento, desde que não prejudique seu valor nutritivo.

\subsubsection{Acidulantes}

Os acidulantes desempenham funções importantes: abaixam o pH do produto, diminuindo a resistência dos microrganismos, tornam a bebida mais agradável ao paladar, estimulam as glândulas salivares, seqüestram metais que possam causar alterações nas características organolépticas da bebida e provocam a inversão do açúcar, evitando a sua cristalização (Almeida, 1996b).

Nas indústrias de bebidas utiliza-se uma maior quantidade de acidulantes, quando comparado com outros produtos. Em bebidas, é essencial para se manter o equilibrio de sabor e acidez; na inibição microbiana aumentando a vida de prateleira e como quelantes de ions metálicos, que são prejudiciais à cor e ao sabor de algumas bebidas alcoólicas e carbonatadas (Deshpande et al. 1995).

Dentre os acidulantes mais utilizados destacam-se o ácido acético, ácido ascórbico, ácido cítrico, ácido lático, ácido málico, ácido fosfórico e o ácido tartárico. 


\subsubsection{1 Ácido Cítrico}

O ácido cítrico é um ácido orgânico de ampla aplicação na indústria alimentícia graças a sua alta solubilidade, sabor característico de frutas citricas, baixissima toxidade e boa ação quelante sobre certos metais. É considerado como GRAS (Generally Recognized As Safe) pelo FDA (Food and Drug Administration) americano, sendo um dos ácidos mais encontrado na natureza (Almeida, 1996b).

É um dos ácidos mais utilizado em bebidas carbonatadas; comercialmente é empregado como sinergista para antioxidantes retardando reações de escurecimento e também para abaixar o $\mathrm{pH}$; dessa forma, sua aplicação propicia processo térmico mais ameno, o que colabora para a manutenção das caracteristicas naturais da fruta (cor, sabor e teores de vitaminas).

\subsubsection{Conservantes}

Desde a pré-história o homem tem se esforçado para preservar os alimentos do processo de deterioração.

Processos térmicos, secagem, fermentação e refrigeração têm sido usados para prolongar a vida-de-prateleira dos alimentos. São muitos os conservantes químicos empregados na alimentação; os mais antigos são o sal, os nitritos e os sulfitos. Uma das razões para o aumento do uso de conservantes é a mudança no padrão de produção e de comercialização dos alimentos. Nos dias de hoje os consumidores encontram todo tipo de alimento, durante 0 ano inteiro. Isso só é possivel porque são alimentos com vida-de-prateleira longa e livres de microrganismos deterioradores e de patogênicos. Embora atualmente as embalagens e os processos aplicados no processamento de alimentos sejam suficientes para sua conservação, os conservantes químicos ainda são utilizados para garantir a estabilidade microbiológica dos produtos armazenados, principalmente quando a comercialização é realizada em paises tropicais, como o Brasil (Davidson \& Juneja, 1990).

Dentre os conservantes mais utilizados destacam-se o benzoato de sódio, 0 ácido p-hidroxibenzóico e seus ésteres; ácido sórbico e seus sais de sódio e potássio; ácido propiônico e seus sais; dióxido de enxofre e sulfito; ácido acético e acetatos; nitritos e nitratos. 


\subsubsection{1 Ácido Sórbico e Derivados}

É certo que o emprego de aditivos em produtos alimentícios é algo altamente questionável. Normalmente utilizados na preservação dos alimentos, os sorbatos são aditivos eficientes, de baixa toxicidade (Antunes \& Oliveira,1983).

As frutas e seus produtos derivados (sucos, refrescos, néctares, refrigerantes e xaropes) normalmente apresentam valores de $\mathrm{pH}$ abaixo de 4,0, razão pela qual os problemas de deterioração a que estão sujeitos limitam-se aos microrganismos tolerantes ao meio ácido, com predomínio de bactérias lácticas, leveduras e fungos (Uboldi Eiroa,1989). Além do mais, bactérias patogênicas não se desenvolvem nem sobrevivem por muito tempo em tais níveis de pH (Leitão et al., 1977).

O sorbato age pelas moléculas não ionizadas do ácido sórbico, resultantes da hidrólise do sal. Portanto, quanto maior o pH do meio, menor será a concentração de moléculas de ácido sórbico formado e menor será seu efeito inibidor sobre microrganismos (Falcone \& Piepke, 1964).

O ácido sórbico é o único ácido orgânico insaturado produzido sinteticamente, e de uso permitido como conservante em alimentos. Por causa do seu sabor neutro, seu uso é recomendável em sucos e bebidas em geral, sendo eficientes no controle de fungos e leveduras e pouco eficientes no controle de bactérias. $O$ ácido sórbico é ligeiramente solúvel em água $\left(0,16 \mathrm{~g} / 100 \mathrm{ml} \mathrm{H}_{2} \mathrm{O}\right)$, porém o sal é bastante solúvel $\left(139 \mathrm{~g} / 100 \mathrm{ml}\right.$ a $20^{\circ} \mathrm{C}$ ). $\mathrm{O} \mathrm{pH}$ ótimo de sua atuação estende-se até pH 6,0 (Araújo, 1990).

A ação do ácido sórbico e seus sais contra bolores, leveduras e bactérias é inteiramente dependente do $\mathrm{pH}$ do substrato; à medida que se abaixam os valores de $\mathrm{pH}$, a quantidade de ácido não-dissociado livre aumenta, sendo esta a forma ativa de inibição (Bell et al., 1959). Também os sais nessa faixa de pH dissociam-se, dando radicais ácidos que atuam ativamente na inibição microbiana. Dessa maneira, pode-se concluir que o uso eficiente dos sorbatos como agentes antimicrobianos deve ser feito em valores de $\mathrm{pH}$ que resultem em altas concentrações de ácido em forma nãodissociada. $\mathrm{Em} \mathrm{pH} \mathrm{4,8,50 \%} \mathrm{do} \mathrm{ácido} \mathrm{está} \mathrm{na} \mathrm{forma} \mathrm{não-dissociada,} \mathrm{o} \mathrm{que} \mathrm{indica} \mathrm{que}$ em valores de $\mathrm{pH}$ iguais ou menores que 4,8 tem-se, pelo menos, metade do total de ácido sórbico na forma ativa (Antunes \& Oliveilra, 1983). 
Almeida (1996b) explica que para o ácido sórbico desenvolver sua atividade no interior da célula, é necessário que atravesse a parede do mesmo, o que é realizado principalmente pelas moléculas não dissociadas. A ação é melhor quanto menor for o $\mathrm{pH}$ do meio, pois em pH 3,0,98\% do ácido sórbico apresenta-se não dissociado, e em $\mathrm{pH} 7,0$, apenas $0,6 \%$.

A ação antimicrobiana do ácido sórbico ocorre devido à inibição de diversas enzimas nas células, especialmente enzimas dos hidratos de carbono. Intervêm também de forma ativa no ciclo do citrato (Almeida, 1996b).

A propriedade inibidora do ácido sórbico (ácido hexadienoico) foi notada pela primeira vez por Gooding, em 1945. Vários estudos demonstraram que o ácido sórbico é mais eficiente e menos tóxico do que o ácido benzóico (como conservante alimentar) já que o ácido sórbico é metabolizado da mesma forma que os ácidos graxos (Hansen \& Appleman, 1955), sendo inofensivo como componente dietético (Bell et al., 1959).

Bell et al. (1959) verificando a ação do ácido sórbico no desenvolvimento de bactérias, leveduras e bolores, notaram que de 104 microrganismos estudados, todos cresceram em meio de cultura contendo $0,1 \%$ de ácido sórbico, em pH 7,0. Na mesma concentracão do aditivo, os bolores e as leveduras foram inibidos em $\mathrm{pH} \mathrm{4,5} \mathrm{e} \mathrm{as}$ bactérias lácticas foram inibidas em $\mathrm{pH} 3,5$. Observaram também que na faixa de $\mathrm{pH}$ compreendida entre 4,8 e 6,0 a eficiência é mínima, enquanto que na faixa de pH entre 3,1 e 4,8 a eficiência é máxima.

Falcone \& Piepke (1964) estudando a eficiência do sorbato de potássio em suco de abacaxi, verificaram que este conservante pode ser utilizado em sucos ácidos, pois foi capaz de inibir o crescimento de fungos e leveduras inoculadas no suco. $O$ desenvolvimento de espécies de Byssochlamys em sucos também pode ser prevenido pela adição de $0,025 \%$ de benzoato de sódio ou de sorbato de potássio (Hocking \& Pitt, 1984).

Uboldi Eiroa et al. (1984), compararam a eficiência de benzoato de sódio, sorbato de potássio e metabissulfito de potássio na inibição da levedura Zygosaccharomyces baillii em suco de laranja reconstituido, com variação das concentrações e do número de células contaminantes. O metabissulfito de potássio foi o menos eficiente, mesmo para o controle de uma população relativamente baixa; por outro lado, o benzoato de sódio a $0,1 \%$ foi ineficiente na inibição de populações mais elevadas de células. Finalmente, quando analisado comparativamente, o sorbato de 
potássio apresentou melhores resultados, inibindo por completo as baixas populações e restringindo o crescimento, no caso de inóculos mais altos.

Segundo Almeida (1995), o sorbato de potássio não possui ação mutagênica e nem teratogênica. O limite máximo de sorbato de potássio permitido no Brasil é de $0,1 \%$ no produto (Antunes \& Canhos, 1982).

\subsubsection{Aditivos Nutricionais}

Durante os processos de colheita e armazenamento da matéria-prima, industrialização e comercialização dos produtos, ocorrem perdas de vitaminas e outros nutrientes. O consumidor, consciente dessas perdas, procura consumir cada vez mais alimentos que contenham os nutrientes naturais necessários à manutenção da saúde, mas isso é praticamente impossível. Preocupadas com essa deficiência, as indústrias procuram repor, e até mesmo enriquecer os alimentos industrializados com vitaminas e outros nutrientes, atendendo a necessidade nutricional da população (Tavares, 1990).

A ciência nutricional tem evoluído com o uso de aditivos nutricionais, como vitaminas, minerais, aminoácidos e ácidos graxos. Estes aditivos são utilizados em formulações de alimentos como complemento nutricional e também para repor o nutriente que degradadou-se durante o processamento. Os aditivos nutricionais são acrescentados em quantidades adequadas às necessidades do organismo.

\subsubsection{1 Ácido Ascórbico}

A adição do ácido ascórbico em alimentos prevê a reposição desta vitamina que normalmente se perde durante o processamento e armazenamento dos alimentos.

O ácido ascórbico é usado para evitar reações de oxidação, mantendo assim a cor natural em carnes, frutas e outros alimentos susceptiveis a este tipo de reação (Sherwin, 1990); como acidulante, é usado par ajustar o pH e prevenir o escurecimento enzimático das frutas e hortaliças pela inibição da polifenol oxidase (Deshpande et al., 1995). 
Askar et al. (1994) observaram que a adição de $100-400 \mathrm{mg} \mathrm{kg}^{-1}$ de polpa de ácido ascórbico durante o processamento de néctar de manga, mantém a cor estável por 6 meses de armazenamento.

Ramana et al. (1984) congelaram polpa de manga e utilizaram ácido ascórbico $\left(50 \mathrm{mg} 100 \mathrm{~g}^{-1}\right)$ para reter a cor, o sabor e aroma da fruta durante o armazenamento.

\subsection{Cor e Aroma}

Para obter um néctar de boa qualidade, é necessário a manutenção de alguns fatores, como a cor, o sabor, o aroma e a viscosidade, além do seu valor nutricional. Portanto, durante o processamento de um néctar, é importante que sejam minimizadas as alterações nutricionais e organolépticas, mantendo o máximo de qualidade da fruta fresca.

A oxidação dos carotenóides ocasionam a perda da cor característica dos sucos (descoloração). Os carotenóides são pigmentos responsáveis pelas cores, desde o amarelo até o vermelho-alaranjado da maioria das frutas (Alves \& Garcia, 1993).

Reações envolvendo ácido ascórbico, são reconhecidas como importantes no escurecimento de sucos no armazenamento. Trabalhos apresentados por Graumlich et al. (1986) e Alves \& Garcia (1993), mostraram o relacionamento entre perda de ácido ascórbico e escurecimento. É provável que a Vitamina $\mathrm{C}$ do suco seja convertida lentamente em compostos precursores de pigmentos escuros. As perdas de vitamina C ocorrem principalmente através de reações de oxidação, e mesmo, pequenas quantidades de oxigênio dissolvido são capazes de, em função da temperatura de armazenamento, conduzir a certas perdas de Vitamina C (Gava, 1985).

De Martin (1969) aconselha que após o despolpamento, a polpa da goiaba seja levada diretamente a um desaerador para retirar o ar dissolvido, pois o oxigênio prejudica consideravelmente a qualidade do produto. Pode ocorrer perda da coloração da polpa, queda considerável no teor de vitaminas (principalmente vitamina $\mathrm{C}$ ), perda de sabor e aparecimento de sabor estranho. Além desses fatores negativos, a presença de oxigênio também causa desuniformidade no enchimento mecânico das latas, pela variação do espaço livre e, consequentemente, do seu peso. Portanto, durante o processamento de frutas, podem ocorrer reações, importantes ou não na 
formação de compostos aromáticos voláteis que são, na maioria das vezes, responsáveis pelo odor e sabor do produto final (Figueiredo \& Uzelac, 1976).

A maioria das transformações químicas nos tecidos vivos é efetuada pela ação de enzimas. Essas transformações podem ocorrer antes, durante e após o amadurecimento da fruta, ou durante o processamento. Assim, na goiaba, as proteáses, amiláses, celuláses e pectináses devem ser inativadas durante 0 processamento, acontecendo o mesmo com o purê de mamão. Neste caso, o desenvolvimento de aroma estranho é motivado por ação enzímica ou agentes microbiológicos. O ajustamento do pH (acidificação) e a inativação enzímica pelo calor, são técnicas que devem ser utilizadas no processamento para evitar tais problemas (Figueiredo \& Uzelac, 1976).

Alterações organolépticas foram observadas durante o armazenamento de suco de acerola a temperatura ambiente, principalmente na cor do suco, que apresentou pigmentos escuros após um determinado tempo de armazenamento. $O$ tempo de armazenamento afetou também o sabor do suco (Rocha, 1988).

\subsection{Alimentos Dietéticos}

De acordo com Gava (1986), a sacarose apresenta um grau de doçura que é considerado padrão para qualquer outro tipo de adoçante, calórico ou não. Entre outras características, pode-se mencionar a propriedade de auxiliar na textura (conferindo corpo ou tomando-a mais plástica); proporcionar coloração e sabor, no caso de alimentos que serão aquecidos (caramelização); potencializar o aroma e sabor do alimento; atuar na conservação, ou ainda, servir como umectante.

Não menos importante é o aspecto nutricional ligado à adição de açúcar na formulação de alimentos, já que um dos principais motivos de sua adição é conferir um certo teor calórico ao produto.

No caso específico de bebidas não alcoólicas, mais precisamente refrigerantes, o açúcar desempenha três funções principais, do ponto-de-vista tecnológico: conferir doçura (que é intrínseca à natureza do produto), conferir "corpo" (sem o qual a bebida se apresentaria aguada ao paladar) e realçar o sabor de outros componentes da bebida (através de um equilíbrio entre a doçura e a acidez do produto e atuando ainda como suporte de aromas) (Gava, 1986). 
Não obstante a importância tecnológica, sensorial e nutricional do açúcar, um segmento significativo da sociedade deseja ou necessita restringir o consumo deste nutriente energético. Esta restrição se dá por motivos varlados, como no caso de enfermidades tipo diabetes mellitus e cardiopatias, ou por disfunções tais como a hiperlipemia e a obesidade ou, ainda, pelo desejo de controlar o peso e manter a silhueta.

Segundo Halpern et al. (1991), na década de 60 , começaram a surgir os primeiros indicios de alternativas para o consumo do açúcar, visando a atender inicialmente aos pacientes diabéticos, hipertensos e obesos.

Anos mais tarde, a preocupação com a forma física e com hábitos de vida saudáveis colocaram em evidência um produto que se consolidou definitivamente na década de 80: os edulcorantes e seus derivados da chamada linha dietética (Monego, 1994).

Os produtos dietéticos têm revolucionado o mercado alimentício e conquistado consumidores diabéticos, obesos e com distúrbios orgânicos e um grande número de pessoas saudáveis, preocupadas com a saúde e a boa forma física (Menezes \& Viegas,1990). O ano de 1980 foi o grande marco na introdução desses produtos no Brasil, haja vista a modificação na legislação brasileira, que deixou de classificá-los como medicamentos, abrindo, assim, as portas para a entrada de novos adoçantes e uma infinidade de produtos formulados e prontos para o consumo (Monego et al., 1994).

De acordo com a legislação em vigor, o termo dietético possui sentido amplo e não se aplica apenas aos alimentos isentos de açúcar ou de baixas calorias.

Alimentos dietéticos estão incluídos na categoria de Alimentos para Fins Especiais e são classificados como aqueles especialmente elaborados e, ou, produzidos de forma que sua composição atenda às necessidades dietoterápicas específicas de pessoas com exigências físicas, metabólicas, fisiológicas e, ou, patológicas particulares. São classificados nessa categoria alimentos para dietas com restrição de açúcares, sódio, gorduras, colesterol, aminoácidos ou proteínas, alimentos para dietas de controle de peso, alimentos para dietas administradas por sondas e alimentos para dietas modificados em sua estrutura molecular (Brasil, 1995a e b). Podem, portanto, ser ricos em calorias, como os produtos alimentícios (tipo 
"Sustacal" e "Meritene"), destinados a convalescentes, ou incluir menos gordura e sal para um melhor controle do colesterol e da pressão arterial (Lemes, 1990).

Dados da Associação Brasileira da Indústria de Alimentos Dietéticos (Abiad) relatam que os produtos "diet" e 'light" representam menos de $1 \%$ das vendas totais de produtos alimentícios (nos Estados Unidos a participação é de 36\%). No entanto, notamos uma tendência crescente de aumento do uso de edulcorantes nos alimentos, seguindo então o padrão americano, em que de cada 100 produtos, 30 têm edulcorantes em sua fórmula. No Brasil, essa proporção ainda é de 3\% (Borschiver et al. 1998).

Enquanto os produtos "diet" têm uma indicação especifica, os "light" não têm. O alimento "light" é aquele modificado do convencional com redução mínima de $25 \%$ de calorias por meio da diminuição de um ou mais de seus componentes. Normalmente os alimentos "light" são consumidos por pessoas que não têm uma patologia específica. São pessoas saudáveis e que estão buscando produtos de melhor qualidade nutritiva (Rodrigues, 1995).

\subsubsection{Sorbitol}

O sorbitol $\mathrm{C}_{6} \mathrm{H}_{12} \mathrm{O}_{6}$, de peso molecular 182,17 (D-glucitol) é um edulcorante calórico natural; é um álcool hexahídrico, também chamado de hexitol ou poliol. A descoberta desse edulcorante data de mais de um século, mas somente na década de 30 o sorbitol passou a ser produzido industrialmente (O Mercado Diet,1990).<smiles>COC(O)C(O)C(O)CO</smiles>

Sorbitol - Fonte Narbors e Gelardi, 1991.

É o poliol mais encontrado na natureza, ocorrendo, em concentrações relativamente elevadas em maçãs $(0,2$ a $1 \%)$; pêras $(1,2$ a $2,8 \%)$; pêssegos $(0,5$ a $1,3 \%)$; ameixas (1,7 a 4,5\%); cereja, cebola, algas marinhas, abóboras, fungos e em 
bebidas fermentadas como cidra (5-6 g/L) (Almeida, 1996a; Giese, 1993; Angelucci, 1993; Cândido \& Campos, 1996).

Como as quantidades de poliol presentes na natureza não são suficientes para extração comercial, industrialmente são obtidos pela hidrogenação catalítica sob pressão, dos açúcares. Assim ocorre com o sorbitol, que é obtido da glicose; o manitol, da frutose; o maltitol e o isomaltitol, da maltose; o lactol, da lactose, e o xilitol, da xilose (Almeida, 1996a; Giese,1993; Angelucci, 1993; Cândido \& Campos, 1996).

O sorbitol possui o equivalente a 0,5 a 0,7 vezes a doçura da sacarose e seu IDA (Ingestão Diária Aceitável) não foi especificado na última avaliação (Almeida, 1996a), pois está dentre as substâncias com toxidade tão baixa ou desprezivel que, quando usadas dentro dos niveis tecnológicos necessários para se alcançar os efeitos desejados, e dos seus niveis de aceitação nos alimentos, não apresentam perigos à saúde humana (Angelucci, 1993). O sorbitol não é toxico, mutagênico, teratogênico ou carcinogênico, tem excelente estabilidade química, bacteriológica, e térmica (Cândido \& Campos, 1996).

O sorbitol, assim como outros hexitóis, possui um valor calórico de aproximadamente $4 \mathrm{kcal} / \mathrm{g}$, semelhante à sacarose. Entretanto, no que diz respeito à sua disponibilidade energética, deve-se considerar o valor de 2,4 kcal/g, recomendado pela Comunidade Econômica Européia, em 1990 (Monego et al. 1994).

Apesar de não ser considerado tóxico, doses excessivas de sorbitol por via oral podem causar flatulência e desconforto abdominal. Doses acima de 20-30 g/dia podem resultar em efeito diurético, e acima de 30 a $70 \mathrm{~g} /$ dia, efeito laxativo (Cândido \& Campos, 1996). Mas pode haver um aumento da tolerância ao produto por ocasião do consumo regular (Sorbitol, 1997).

De acordo com Monego et al. (1994) e Cândido \& Campos (1996), o sorbitol é comumente utilizado em produtos para fins dietéticos especiais indicados para diabéticos, como: biscoitos, refrigerantes, chocolates, geléias, balas. É o ingredientepadrão em gomas de mascar, não apresentando propriedades cariogênicas.

Diferente dos açúcares, os polióis não são integralmente metabolizados, por serem absorvidos lenta e parcialmente no intestino delgado por difusão passiva. A parcela absorvida é metabolizada independentemente de insulina, o que é altamente benéfico para o metabolismo dos diabéticos (Angelucci, 1993). 
O diabetes mellitus é um distúrbio metabólico caracterizado pelo nivel elevado de glicose sangüinea (hiperglicemia) e pela excreção do excesso de glicose na urina (glicosúria), vinculado com o metabolismo de carboidratos, proteínas e lipídios. O metabolismo anormal é o resultado de uma deficiência absoluta ou relativa na produção de insulina pelo pâncreas (Mahan e Arlin, 1995).

A cárie dentária é uma doença característica de indivíduos que, concomitantemente, apresentam dentes susceptiveis, dispõem de microflora bacteriana oral favorável e consomem dieta cariogênica. É possivel substituir os açúcares convencionais e o amido dos alimentos pelo manitol e pelo sorbitol, polióis que não fermentam facilmente.

Desta forma, a dieta com esses polióis e dita não cariogênica pois não propiciam a fermentação e, não permitem a formação do ácido lático, mantendo assim o pH da saliva. Evita-se então a formação da cárie dentária (Angelucci, 1993).

\subsection{Alteraçōes durante Armazenamento}

Djanikian et al. (1996), estudando quimica e fisicamente sucos de maracujá e acerola, não pasteurizados, armazenados a $4^{\circ} \mathrm{C}$, durante 30 dias verificaram que não houve variação de $\mathrm{pH}$, de acidez titulável e do Brix, enquanto que o conteúdo de ácido ascórbico sofreu redução contínua (70,5\% e $26,6 \%$ respectivamente).

Souza Filho et al. (1992), processando xarope de cajú pasteurizado verificaram que 0 produto teve boa estabilidade durante 120 dias de armazenamento, apresentando decréscimo de apenas $15,66 \%$ em relação ao seu teor original de vitamina $C$. Concluiram também que o produto apresentou-se estável quanto às características químicas e físico-quimicas, pois não houve alteração dos valores de $\mathrm{pH}$, de acidez e de sólidos solúveis.

Okoli \& Ezenweke (1990), estudando a vida de prateleira de suco de mamão pasteurizado com conservante, verificaram que quando armazenado, a $10^{\circ} \mathrm{C}, \circ$ Brix, acidez titulável e o pH, não apresentou mudanças significativas durante um período de aproximadamente dois anos. A amostra-controle armazenada à mesma temperatura apresentou indício de deterioração microbiana depois de um ano, com aumento da acidez titulável e redução do pH e Brix. 
De Martin et al. (1972) estudaram o comportamento químico dos néctares de mamão processados pelos métodos de enchimento a quente e cozimento rotativo, armazenados em temperatura ambiente por 180 dias. As análises químicas dos néctares mostraram que apenas o teor de ácido ascórbico sofreu redução $(26,9 \%$ e 28,9\% respectivamente, após 180 dias). Estes resultados são facilmente explicáveis pela presença sempre constante de oxigênio, mesmo que em quantidades mínimas.

Salomón et al. (1977) processaram néctares de abacaxi-maracujá e de abacaxi-laraja e observaram que após 180 dias de armazenamento, a viscosidade diminuiu, o que provavelmente ocorreu devido à hidrólise da pectina contida nos produtos. Em relação à cor, notaram um certo escurecimento dos néctares durante o armazenamento. Observaram ainda um aumento no teor de açúcares redutores durante o armazenamento, bem como uma diminuição no teor de ácido ascórbico nas formulações.

Mostafa et al. (1997) processaram néctares mistos de polpa de mamão e de manga e observaram que a quantidade de ácido ascórbico caiu pela metade durante o armazenamento, em todas as amostras. Notaram também aumento da acidez, o que segundo Okoli \& Ezenweke (1990) pode ser devido a microrganismos que se desenvolveram no periodo. Ainda no armazenamento observaram escurecimento das amostras, principalmente na formulação de $20 \%$ de mamão + $0 \%$ de manga.

Askar et al. (1996) processando néctar de pêssego, notaram que as amostras armazenadas a $37^{\circ} \mathrm{C}$ ficaram descaracterizadas quanto ao sabor, após seis meses de armazenamento. O conteúdo de ácido ascórbico diminuiu com o aumento do grau de descoloração e com o aumento do periodo de armazenamento e com maior temperatura. Concluiram que o armazenamento em altas temperaturas reduz a vida útil do produto acondicionado em latas ou em vidros.

Sanchez-Nieva (1955) em seu estudo feito com suco de acerola, mostrou que o processo de pasteurização feito em trocador de calor tubular a $88^{\circ} \mathrm{C}$, por 45 segundos, ocasionou perdas de $2 \%$ no teor de ácido ascórbico. O processo de aquecimento provocou também alteração da cor vermelha para laranja avermelhado ou amarela. Alterações de cor ocorridas podem estar relacionadas à decomposição de pigmentos, provavelmente antocianinas, que exibem um comportamento similar quando aquecidas em presença de ácido ascórbico. 
Oliva et al. (1996) pesquisaram a estabilidade do néctar de acerola obtido por dois processamentos térmicos, utilizando-se trocador de calor de placas e enchimento a quente ("Hot Fill") e trocador de calor rotativo ("Spin Cooker-Cooler"). Observaram que o armazenamento em temperatura ambiente é bastante crítico para a estabilidade do néctar de acerola e nestas condições as perdas de ácido ascórbico são relativamente elevadas quando comparadas ao produto armazenado sob refrigeração. As alterações de sabor e cor nas amostras armazenadas em temperatura ambiente foram detectadas pelos provadores na avaliação organoléptica e na análise instrumental de cor.

Baramanray et al. (1995) utilizando variedades hibridas e comerciais de goiabas para produção de néctares, observaram que durante o armazenamento ocorreu escurecimento, aumento do Brix, da acidez e dos açúcares totais e redutores nas amostras. Já, o ácido ascórbico, a pectina e as características organolépticas diminuíram com o aumento do periodo de armazenamento. Concluíram que o néctar de melhor qualidade foi aquele preparado com as variedades hibridas, por apresentarem alto teor de sólidos solúveis, baixa acidez, menos sementes e mais polpa.

Kalra e Tandon (1984) estudaram néctar de goiaba enriquecido com vitamina C (19/kg) e armazenado por 10 meses em garrafas de vidro. A avaliação organoléptica indicou que a amostra que continha $14^{\circ}$ Brix $/ 0,25 \%$ de acidez era a melhor, seguida das amostras que apresentavam as formulações $14^{\circ}$ Brix $10,20 \%$ de acidez e $12^{\circ}$ Brix $/ 0,25 \%$ de acidez. Durante o armazenamento dos néctares foi observado decréscimo de Brix e de vitamina $\mathrm{C}$ e aumento no teor da acidez titulável.

Askar et al. (1993) trabalhando com néctar de manga, relataram que a adição de ácido ascórbico no início do processamento e o acondicionamento em latas envernizadas com estanho são medidas recomendadas para aumentar a vida de prateleira do néctar. Observaram também que a preservação da cor, do sabor e de vitamina $\mathrm{C}$, era maior nas amostras armazenadas a $21^{\circ} \mathrm{C}$, com um ano de vida útil. Já, para o néctar armazenado em temperatura ambiente, o periodo não excedeu 6 meses. 


\section{MATERIAL E MÉTODOS}

O experimento foi conduzido no Setor de Processamento de Frutas e Hortaliças, do Departamento de Agroindústria, Alimentos e Nutrição da Escola Superior de Agricultura "Luiz de Queiroz" - USP.

\subsection{Matéria-prima}

No presente trabalho foram utilizadas as variedades de goiaba Paluma e Pedro Sato, procedentes da cidade de Monte Alto, Estado de São Paulo. As goiabas foram recebidas no laboratório em lotes de $20 \mathrm{~kg}$ de cada variedade, no mesmo dia da colheita, e armazenadas a $4^{\circ} \mathrm{C}$ até o processamento, que não ultrapassou 48 horas após o seu recebimento.

Colheram-se frutas maduras e amareladas, que são próprias para 0 processamento. Segundo Garcia (1978), a fruta deve adquirir o seu típico colorido amarelo na própria planta, estar madura, porém deve estar ainda firme, quando o destino for o processamento.

As variedades Paluma e Pedro Sato foram escolhidas para este experimento porque há poucas pesquisas sobre a primeira e nenhuma sobre segunda. Além disso, possuem propriedades que indicam serem adequadas ao processamento de néctares.

\subsection{Caracterização da Matéria-prima}

\subsubsection{Análises físicas}

a) Rendimento em purê: Para as determinações de rendimento em purê da matériaprima, foram utilizadas amostras de $1000 \mathrm{~g}$ de frutas, tomadas aleatoriamente dos lotes 
do material. As goiabas depois de pesadas, lavadas e drenadas por 15 minutos, foram desintegradas em despolpadeira Itametal, modelo $0,25 \mathrm{df}$, com peneira de $0,2 \mathrm{~mm}$, obtendo-se assim o purê. Os resultados são expressos em porcentagem de purê pronto para o processamento, em relação ao peso bruto da matéria-prima.

b)Textura: Para se determinar a textura das goiabas, foi utilizado o "Texture Testing System" (texturômetro), modelo Tp-1, acoplado a um registrador automático de variações de força, operando com célula-padrão de compressão e cisalhamento CS-1, com 10 lâminas de $1 / 8$ polegada de espessura e ângulo de $90^{\circ}$. O instrumento estava provido de um sensor eletrônico de 300lbf e a velocidade de descida do pistão foi de $20 \mathrm{~cm} \mathrm{~min}^{-1}$.

As goiabas foram cortadas ao meio no sentido transversal; cada pedaço pesando aproximadamente 60 gramas, foi colocado na célula teste com a parte cortada (plana) voltada para baixo. Os resultados estão apresentados em $\mathrm{lbf} \mathrm{g}^{-1} \mathrm{de}$ amostra.

\subsubsection{Análises químicas}

a)Ácido ascórbico: Foi determinado por extração em ácido oxálico e pela titulação, segundo Método de Tillmans (Ranganna, 1977).

As amostras de $10 \mathrm{~g}$ de goiaba foram trituradas em liquidificador com $50 \mathrm{ml}$ de ácido oxálico a 4:1000, durante três minutos. A seguir, a mistura foi passada para um balão volumétrico de $100 \mathrm{ml}$. O copo do liquidificador foi lavado com porções de $20 \mathrm{ml}$ de ácido oxálico, que eram adicionados ao balão volumétrico de $100 \mathrm{ml}$, até completar o volume. O conteúdo do balão foi filtrado e $2 \mathrm{ml}$ deste foram pipetados para um erlenmeyer de $125 \mathrm{ml}$ e adicionados $50 \mathrm{ml}$ de água destilada; a seguir foi titulado sob agitação, com solução corante de 2,6 diclorofenolindofenol. Os teores de ácido ascórbico das amostras foram calculados tomando-se por base um padrão de ácido ascórbico, previamente determinado. Os resultados são expressos em $\mathrm{mg}$ de ácido ascórbico por $100 \mathrm{~g}$ da amostra.

b) Acidez total titulável: Na determinação da acidez total titulável, $10 \mathrm{~g}$ de matériaprima triturada foram diluidas em $90 \mathrm{ml}$ de água destilada e tituladas com solução de 
hidróxido de sódio $0,1 \mathrm{~N}$ padronizado, tendo como indicador a fenolftaleína a $1 \%$, conforme Kanesiro et al. (1982). Os resultados são expressos em gramas de ácido cítrico por $100 \mathrm{~g}$ de goiaba.

c) pH: foi determinado em potenciômetro digital Quimis. Os resultados são expressos em unidades de $\mathrm{pH}$.

d) Sólidos solúveis totais: foram determinados em refratômetro Atago, modelo $\mathrm{N}-1$. Os resultados são expressos em ${ }^{\circ B}$ Brix (Tressler \& Joslyn, 1961).

Todas as análises físicas e químicas foram efetuadas com duas repetições, utilizando-se amostras tomadas ao acaso dos lotes das duas variedades de goiaba. Os resultados da matéria-prima foram apresentados em médias, com seus respectivos desvio-padrão, correspondentes às repetições.

\subsection{Processamento}

\subsubsection{Elaboração de néctares}

O Fluxograma das operações utilizadas para a elaboração dos néctares de goiaba está indicado na Figura 1

\subsubsection{Despolpamento}

Após recebimento dos lotes de goiaba no laboratório, os frutos foram selecionados e lavados em água corrente. Para cada lote $(20 \mathrm{~kg})$ o procedimento foi o mesmo: os frutos foram cortados ao meio e colocados em uma despolpadeira mecânica ITAMETAL, modelo 0,25df, com peneira de $0,2 \mathrm{~mm}$, obtendo-se o purê, utilizado no processamento dos néctares.

\subsubsection{Formulação dos néctares}

\section{A) Para obtenção de néctares comuns (com sacarose)}

Os néctares foram elaborados em recipientes de aço inoxidável pela mistura 


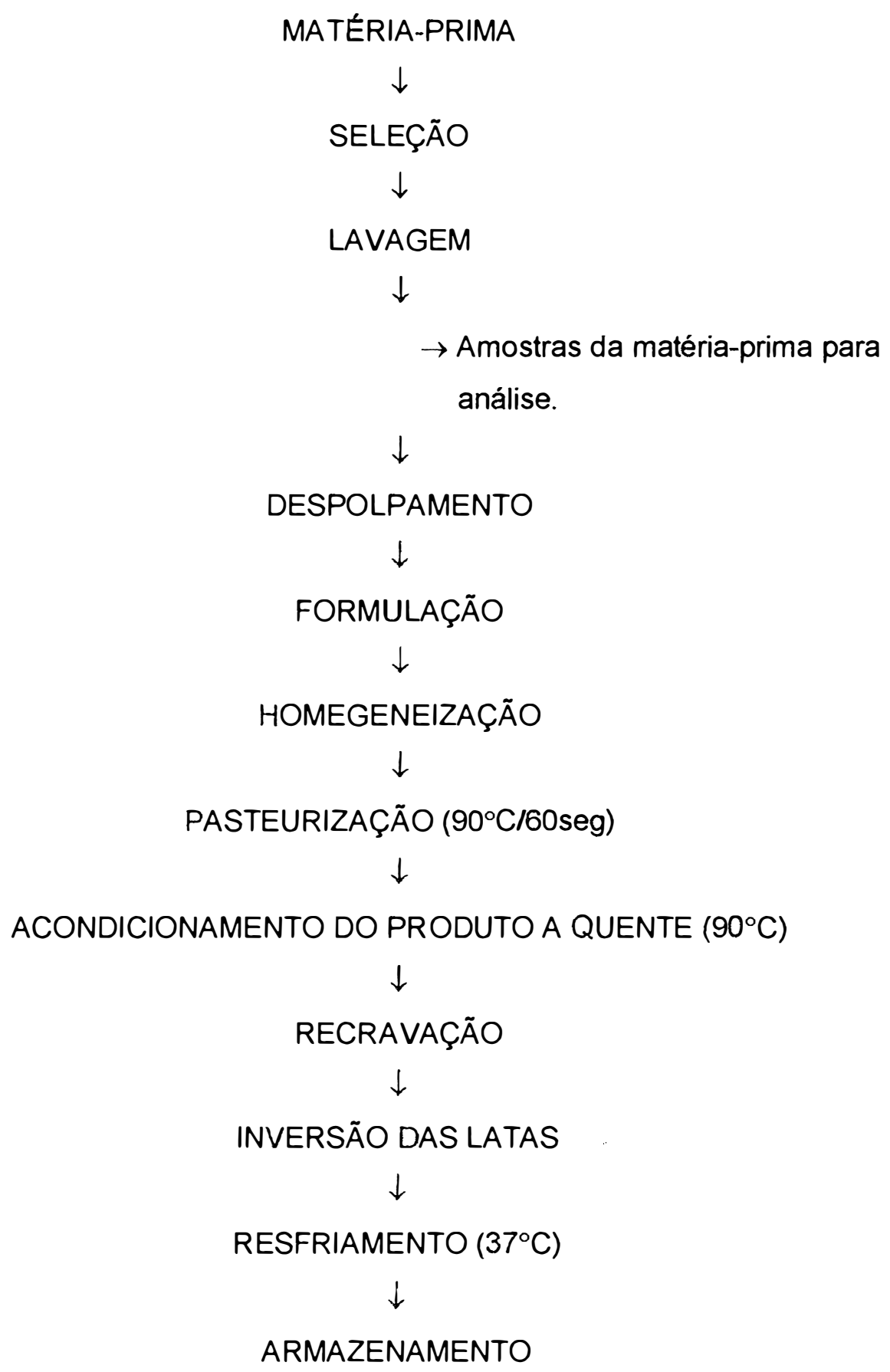

Figura 1 - Fluxograma das operações utilizadas para obtenção de néctares. 
(em peso) de $40 \%$ de purê e $60 \%$ de xarope de sacarose, com ${ }^{\circ}$ Brix suficiente para se obter néctares com Brix de equilíbrio ao redor de $16^{\circ}$. Foi adicionado ácido cítrico em todos os tratamentos para se abaixar o $\mathrm{pH}$ para aproximadamente $(3,6)$, a fim de dar melhor equilíbrio ao sabor do produto. A seguir o néctar foi homogeneizado, aplicandose os tratamentos e pasteurizado por aquecimento em banho-maria em recipientes de aço inóx. Com este aquecimento ocorre uma pequena concentração ocasionando uma elevação do Brix equilíbrio de $16^{\circ}$ para $18^{\circ}$ (valor este considerado ideal em testes preliminares).

\section{a)Tratamentos}

A Figura 2 mostra os tratamentos aplicados para a obtenção dos néctares comuns das duas variedades de goiaba.

\section{Tratamento 1 (T1) : purê de goiaba + xarope de sacarose + ácido cítrico + refrigeração}

Foram feitas duas formulações com este tratamento: uma com o purê do Paluma ( $10^{\circ}$ brix), outra com o purê do Pedro Sato $\left(11^{\circ} \mathrm{brix}\right)$, que foram misturados com xarope de sacarose, com brix suficiente para se obter néctar a $18^{\circ}$ brix (após o tratamento térmico). Os produtos elaborados com esse tratamento foram armazenados a $6^{\circ} \mathrm{C}$.

\section{Tratamento 2 (T2) : purê de goiaba + xarope de sacarose + ácido cítrico}

Este tratamento diferiu do tratamento 1 apenas por ter sido armazenado em temperatura ambiente.

Tratamento 3 (T3) : purê de goiaba + xarope de sacarose + ácido cítrico + sorbato de potássio

Este tratamento diferiu do tratamento 2 porque adicionou-se $0,1 \%$ de sorbato de potássio em relação ao peso do néctar. A quantidade está dentro do limite permitido pela Legislação brasileira (Brasil, 1988). Este aditivo foi utilizado como conservante. 


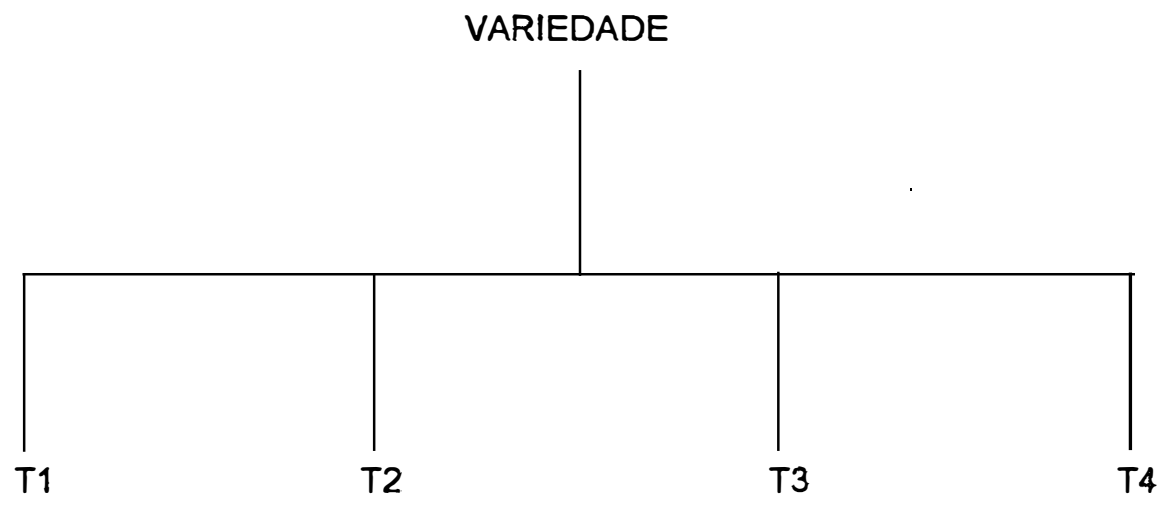

$\begin{array}{cccc}\begin{array}{c}\text { PURE DE GOIABA } \\ +\end{array} & \text { PURE DE GOIABA } & \text { PURE DE GOIABA } & \text { PURE DE GOIABA } \\ \text { XAROPE DE } & + & + & + \\ \text { SACAROSE } & \text { XAROPE DE } & \text { XAROPE DE } & \text { XAROPE DE } \\ + & \text { SACAROSE } & \text { SACAROSE } & \text { SACAROSE } \\ \text { ACIDO CITRICO } & \text { ACIDO CITRICO } & \text { ACIDO CITRICO } & \text { ACIDO CITRICO } \\ + & & + & + \\ \text { REFRIGERAÇÃO } & & \text { SORBATO DE } & \text { SORBATO DE } \\ \left(6^{\circ} \mathrm{C}\right)+ & \text { POTÁSSIO } & \text { POTÁSSIO } \\ & & & + \\ & & & \text { ACIDO }\end{array}$

Figura 2 Esquema de tratamentos aplicados para a obtenção dos néctares comuns das duas variedades de goiaba 
Tratamento 4 (T4) : purê de goiaba + xarope de sacarose + ácido cítrico + sorbato de potássio + ácido ascórbico

Este tratamento diferiu do tratamento 3 porque adicionou-se $0,03 \%$ de ácido ascórbico em relação ao peso do néctar. A quantidade está dentro do limite permitido pela Legislação brasileira (Brasil, 1988). Este aditivo foi utilizado como anti-oxidante e para enriquecer o néctar com vitamina.

B) Para a obtenção de néctares dietéticos (com sorbitol)

O procedimento foi o mesmo utilizado para os néctares comuns, mas neste caso substituiu-se o açúcar pelo sorbitol.

\section{b) Tratamentos}

Os tratamentos aplicados para a obtenção dos néctares dietéticos dos dois cultivares de goiaba estão apresentados na Figura 3.

Tratamento 1 (T1) : purê de goiaba + xarope de sorbitol + ácido cítrico + refrigeração

Foram feitas duas formulações com este tratamento: uma com o purê da Paluma ( $10^{\circ}$ Brix), outra com o purê da Pedro Sato $\left(11^{\circ}\right.$ Brix), que foram misturados com xarope de sorbitol com Brix suficiente para se obter néctar a $18^{\circ}$ Brix (após o tratamento térmico). Os produtos elaborados com esse tratamento foram armazenados a $6^{\circ} \mathrm{C}$.

Tratamento 2 (T2) : purê de goiaba + xarope de sorbitol + ácido cítrico

Este tratamento diferiu do tratamento 1 apenas por ter sido armazenado em temperatura ambiente.

Tratamento 3 (T3) : purê de goiaba + xarope de sorbitol + ácido cítrico + sorbato de potássio

Este tratamento diferiu do tratamento 2 porque adicionou-se $0,1 \%$ de sorbato de potássio em relação ao peso do néctar. A quantidade está dentro do limite permitido pela Legislação brasileira (Brasil, 1988). Este aditivo foi utilizado como conservante. 


\section{VARIEDADE}

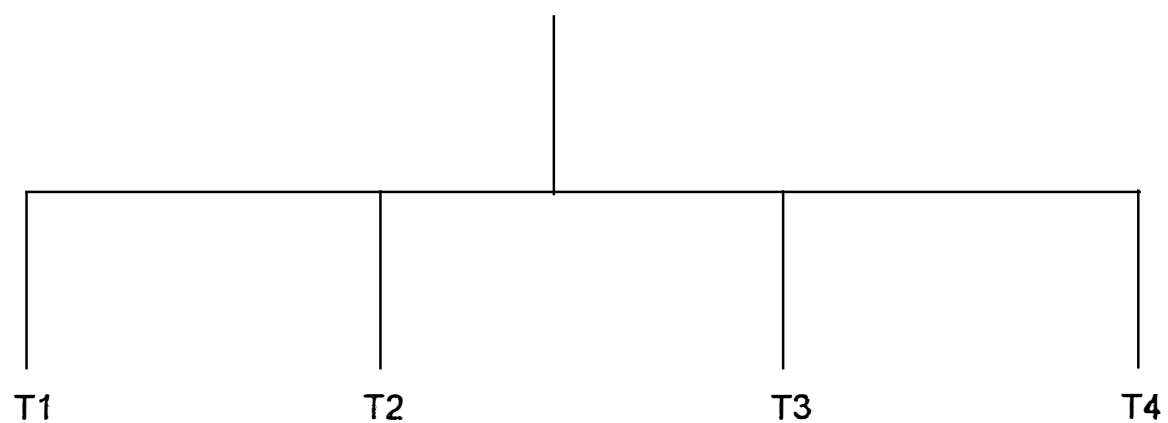

PURE DE GOIABA

XAROPE DE

SORBITOL

$+$

ACIDO CÍTRICO

$+$

REFRIGERAÇĀO

$\left(6^{\circ} \mathrm{C}\right)$
PURE DE GOIABA

XAROPE DE

SORBITOL

ÁCIDO CITRICO
PURÊ DE GOIABA

\begin{tabular}{|c|}
\hline XAROPE DE \\
\hline SORBITOL \\
\hline+ \\
\hline ÁCIDO CITRICO \\
\hline+ \\
\hline JRBATO DE \\
\hline SSIO \\
\hline
\end{tabular}

XAROPE DE
PURE DE GOIABA

XAROPE DE

SORBITOL

ÁCIDO CITRICO

SORBATO DE

POTÁSSIO

ACIDO

ASCÓRBICO

Figura 3 - Esquema dos tratamentos aplicados para a obtenção dos néctares dietéticos das duas variedades de goiaba. 
Tratamento 4 (T4) : purê de goiaba + xarope de sorbitol + ácido cítrico + sorbato de potássio + ácido ascórbico

Este tratamento diferiu do tratamento 3 porque adicionou-se $0,03 \%$ de ácido ascórbico em relação ao peso do néctar. A quantidade está dentro do limite permitido pela Legislação brasileira (Brasil, 1988). Este aditivo foi utilizado como anti-oxidante e para enriquecer o néctar com a vitamina.

\subsubsection{Pasteurização}

A pasteurização foi feita por aquecimento em banho-maria até atingir a temperatura de $90^{\circ} \mathrm{C}$, na qual o néctar foi mantido durante 60 segundos.

\subsubsection{Acondicionamento}

Os néctares foram acondicionados a quente $\left(90^{\circ} \mathrm{C}\right)$, em latas de folha-deflandres, com capacidade de $370 \mathrm{~g}(74,6 \times 95,2 \mathrm{~mm})$, revestidas internamente com verniz epóxi, próprias para produtos ácidos. Em cada lata foram colocados $355 \mathrm{~g}$ de néctar de goiaba, deixando um espaço livre de $5 \mathrm{~mm}$.

\subsubsection{Recravação}

As latas foram recravadas, após o acondicionamento, com o auxílio de recravadeira mecânica.

\subsubsection{Inversão das latas}

As latas, já fechadas, foram invertidas para promover a pasteurização das tampas.

\subsubsection{Resfriamento}


O resfriamento das amostras foi feito imediatamente após a inversão, por imersão das mesmas em tanques com circulação de água fria, até atingir a temperatura de $37^{\circ} \mathrm{C}$.

\subsubsection{Armazenamento}

Os produtos, após o resfriamento, foram codificados e armazenados em prateleiras à temperatura ambiente, salvo aqueles do tratamento 1 , que foram armazenados sob refrigeração $\left(6^{\circ} \mathrm{C}\right)$.

\subsection{Avaliação dos Produtos}

\subsubsection{Análises químicas}

A cada 30 dias foram analisados: ácido ascórbico, acidez total titulável, $\mathrm{pH}$ e sólidos solúveis totais, de acordo com as técnicas descritas nos itens, 3.2.2.a, 3.2.2.b, 3.2.2.ce 3.2.2.d.

\subsubsection{Análises físicas}

a) Vácuo: mediu-se o vácuo das latas que continham os produtos, com o auxílio do vacuômetro Marshaltown, em pol. Hg.

b) Peso bruto: as embalagens contendo néctares foram pesadas em balança semianalítica (com precisão de $0,1 \mathrm{~g}$ ).

c) Peso líquido: foi obtido pesando-se a lata vazia limpa e seca, e descontando-o do peso bruto.

Todas as determinações realizadas no produto final foram efetuadas com duas repetições, em amostras tomadas, aleatoriamente, dos lotes dos produtos processados das duas variedades em estudo. 


\subsubsection{Análise sensorial}

As avaliações das amostras foram realizadas por uma equipe de 8 provadores, previamente selecionados e treinados para este tipo de avaliação, utilizando-se uma escala numérica estruturada de nove pontos (Girardot et al., 1952; Dawson, 1964; e Martin, 1973). Para uma seleção inicial dos provadores, foram utilizadas 50 pessoas. A sacarose foi usada no teste de diluição para se determinar os limites de deteç̧ão e de identificação do gosto doce, selecionando assim os provadores mais sensíveis. A seleção final destes foi feita com os néctares comum e dietético de goiaba, através do teste triangular. A análise sensorial foi efetuada sempre duas horas antes ou duas horas depois das refeições, periodos mais adequados para a realização do teste. Os modelos de fichas utilizados nestas avaliações estão apresentados nas Figuras 5, 6 e 7.

Para a avaliação da consistência e do sabor do produto, os procedimentos foram: utilização de copos de plástico branco $(50 \mathrm{ml})$ inodoros, codificados com números aleatórios de três dígitos e colocados em cabines individuais, iluminadas com luz vermelha, a fim de mascarar a cor dos produtos. Já para a avaliação da cor, as amostras, devidamente codificadas, foram colocadas em placas de petri, as quais foram dispostas aleatoriamente numa bandeja de plástico branco, colocada em local com iluminação de luz fluorescente.

As avaliações foram feitas com duas repetições, em sessões diferentes, de forma que cada provador avaliasse a mesma amostra duas vezes.

\subsubsection{Análises Estatísticas dos Resultados}

\section{a)Matéria-prima}

Os resultados da matéria-prima foram apresentados em médias, com seus respectivos desvio-padrão, correspondente às duas repetições.

b) Néctares comuns e dietéticos 
AVALIAÇÃO SENSORIAL

Produto:

Nome do provador: Data_L_ 1

Por favor, analise as amostras e indique a intensidade do Sabor, de acordo com a escala abaixo:

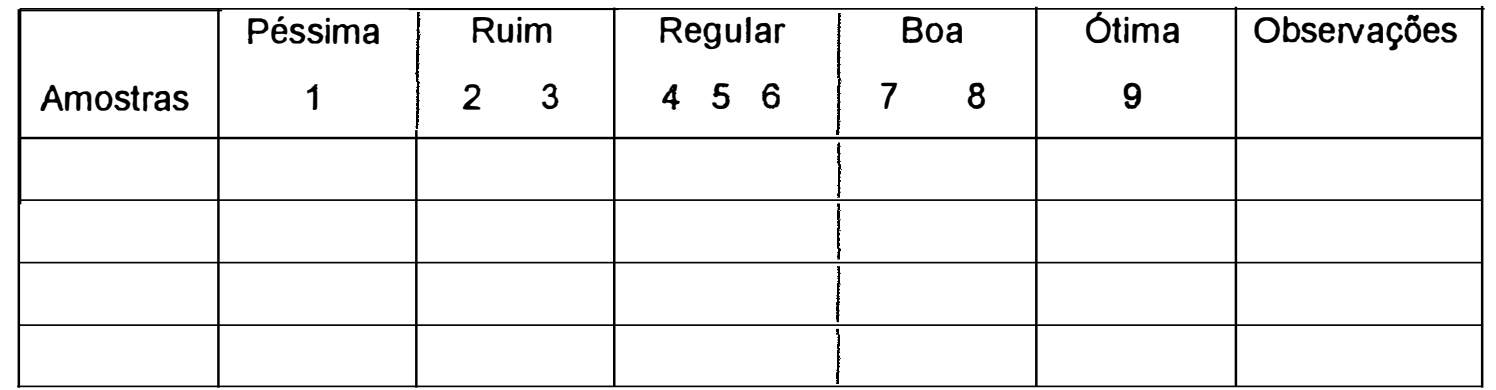

Figura 4 - Modelo de ficha utilizado na avaliação sensorial das amostras de néctar quanto ao sabor.

Por favor, analise as amostras e indique a intensidade da Consistência, de acordo com a escala abaixo:

\begin{tabular}{|c|c|c|c|c|c|c|c|}
\hline & Péssima & Ruim & Regular & Bo & & Ótima & Observações \\
\hline Amostras & 1 & 2 & 456 & & 8 & 9 & \\
\hline & & & & & & & \\
\hline & & & & & & & \\
\hline & & & & & & & \\
\hline & & & & & & & \\
\hline
\end{tabular}

Figura 5 - Modelo de ficha utilizado na avaliação sensorial das amostras de néctar quanto à consistência. 


\section{AVALIAÇÃO SENSORIAL}

Produto:

Nome do provador: Data I I

Por favor, analise as amostras e indique a intensidade da Cor, de acordo com a escala abaixo:

\begin{tabular}{|c|c|c|c|c|c|c|c|c|}
\hline \multirow[b]{2}{*}{ Amostras } & Péssima & & & Regula & \multicolumn{2}{|c|}{ Boa } & Ótima & Obsenvações \\
\hline & 1 & & 3 & 456 & 7 & 8 & 9 & \\
\hline & & & & & & & & \\
\hline & & & & & & & & \\
\hline & & & & & & & & \\
\hline & & & & & & & & \\
\hline
\end{tabular}

Figura 6 - Modelo de ficha utilizado na avaliação sensorial das amostras de néctar quanto à cor.

Os dados de vitamina $\mathrm{C}$, acidez, ${ }^{\circ} \mathrm{Brix}, \mathrm{pH}$, vácuo, peso bruto e peso líquido dos néctares das duas variedades, foram analisados estatisticamente no delineamento inteiramente casualizado, com parcelas subdivididas sendo o tratamento na parcela e a época na subparcela. Foi utilizado o teste $F$ da análise de variância e posteriormente o teste de Tukey para tratamento e regressão polinomial para épocas (Moraes, 1985 e Shirose, 1985). As análises de variância encontram-se em anexo.

Os dados obtidos na avaliação sensorial foram analisados segundo o modelo do delineamento aleatorizado em blocos, em esquema fatorial, onde os blocos foram os degustadores (8) e os fatores foram os tratamentos (T1, T2, T3 e T4) e tempo (30, 60 e 90 dias). Utilizou-se o teste de Tukey ao nível de $5 \%$ de significância. As análises de variância encontram-se em anexo.

Os programas estatísticos utilizados para a análises destes dados foram 0 programa estatístico SAS (Statistical Analyis Sistem), desenvolvido pelo SAS Institute Inc. e o programa SANEST (Sistema de Análise Estatística) para as análises de regressão. 


\section{RESULTADOS E DISCUSSÃO}

\subsection{Caracterização da matéria-prima}

\subsubsection{Análises físicas}

$\mathrm{Na}$ Tabela 1, são apresentados os resultados da avaliação objetiva dos atributos físicos (rendimento e textura).

Tabela 1 - Características físicas de amostras das variedades de goiaba.

\begin{tabular}{lcc}
\hline ANALISES & PALUMA & PEDRO SATO \\
Rendimento (polpa)\% & $88,22+1-0,012$ & $86,53+1-0,007$ \\
Textura (lbf g ${ }^{-1}$ ) & $8,13+/-0,001$ & $7,80+1-0,003$
\end{tabular}

As indústrias, que processam alimentos a partir da polpa da fruta (geléias, néctares e doce em massa), selecionam as frutas (matéria-prima) que contêm maior rendimento-em-polpa. Este procedimento reduz os custos de processamento.

No presente trabalho, o rendimento encontrado nas duas variedades de goiaba, Paluma $(88,22 \%)$ e Pedro Sato (86,53\%), pode ser considerado alto quando comparado com os estudos de Esteves et al. (1984a), que encontraram nos cultivares Brune Vermelha, IAC-4 e São José Piriforme, rendimento em tomo de $70 \%$.

O rendimento em polpa poderá depender do processo utilizado para o despolpamento. O tipo de despolpadeira utilizada influencia na quantidade de polpa extraída, assim, pode-se obter diferentes rendimentos em polpa de uma mesma variedade. Dupaigne (1971), estudando laranjas, verificou que o aspecto e a 
consistência das frutas frescas não dão uma idéia real do teor de suco que delas poderia ser extraído. $O$ rendimento em suco depende também do processo utilizado para sua extração. $O$ autor também demonstrou experimentalmente a influência do tipo de extrator usado na prensagem, obtendo diferentes rendimento em suco de uma mesma variedade de laranja.

Textura é um dos atributos de qualidade mais importante de uma fruta. $\dot{E}$ relacionado com o sabor, porque a liberação de compostos presentes no produto, que são perceptiveis pelo paladar, são também relacionados com a estrutura do tecido. É definida como o "conjunto de propriedades do alimento, compostas por características físicas perceptiveis pelo tato e que se relacionam com a deformação, desintegração e fluxo do alimento, sob a aplicação de uma força". Essas características são avaliadas objetivamente por funções de força, tempo e distância (Chitarra e Chitarra,1990).

As principais sensações que caracterizam a textura são múltiplas, na sua maioria, induzidas por características mecânicas, como: dureza, maciez, fibrosidade, suculência, granulosidade, qualidade farinácea, resistência e elasticidade. Na goiaba, a presença de partículas induz à sensação de granulosidade.

Nascimento et al. (1991) estudando o amadurecimento de goiabas de variedades diferesntes, notaram que as frutas da Paluma, Rica J2, Ogawa Branca, Indiana, L3P11 e E.E.F.3, mantiveram suas texturas firmes durante 0 amadurecimento, o que Ihes poderia proporcionar uma maior longevidade em relação a outras variedades.

À medida que a maturação prossegue, ocorre um aumento de substâncias voláteis, responsáveis pelo aroma e pela modificação da textura das frutas, devido ao aumento da sintese e da atividade de algumas enzimas, tomando-as mais macias. Também ocorrem a síntese e a degradação de pigmento, alterando a cor externa das frutas, a qual passa de verde para amarela

As frutas e hortaliças que irão passar por tratamentos térmicos, e que serão apresentadas ao consumidor em pedaços, devem ser firmes o suficiente para suportar este tipo de tratamento. A textura está diretamente relacionada com o tipo de pectina presente; sabe-se que as pectinas solúveis aumentam com o processo de amadurecimento, tomando frutas e hortaliças menos firmes. 


\subsubsection{Análises químicas}

Os resultados das determinações dos teores de vitamina $\mathrm{C}, \mathrm{pH}$, acidez total titulável e do teor de sólidos solúveis ( ${ }^{\circ} \mathrm{Brix}$ ) da matéria-prima estão a presentados na Tabela 2.

Tabela 2 - Características químicas das variedades de goiaba.

\begin{tabular}{|c|c|c|}
\hline ANALLISES & PALUMA & PEDRO SATO \\
\hline Ácido Ascórbico $\left(\mathrm{mg}^{100 \mathrm{~g}^{-1}}\right)$ & $119,29+/-0,1$ & $114,56+1-0,3$ \\
\hline Acidez Titulável $\left(\mathrm{g} 100 \mathrm{~g}^{-1}\right)$ & $0,29+/-0,015$ & $0,21+/-0,010$ \\
\hline $\mathrm{PH}$ & $3,63+1-0,087$ & $3,85+1-0,025$ \\
\hline Sólidos Solúveis Totais ( ${ }^{\circ}$ Brix) & $10,00+/-0,0$ & $11,00+/-0,499$ \\
\hline
\end{tabular}

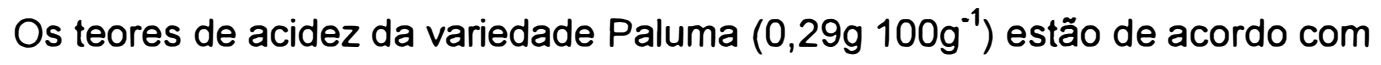
Nascimento et al. (1991); eles encontraram em goiaba dessa mesma variedade 0,28g $100 \mathrm{~g}^{-1}$ de acidez. Esses resultados mostraram-se baixos quando comparados aos de

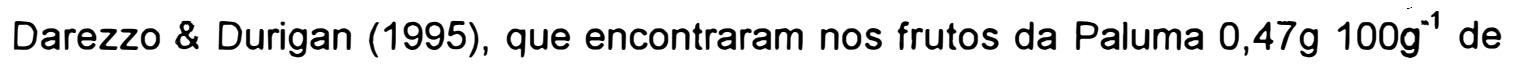
acidez.

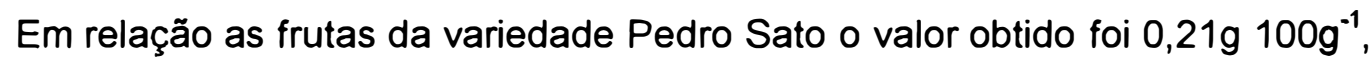

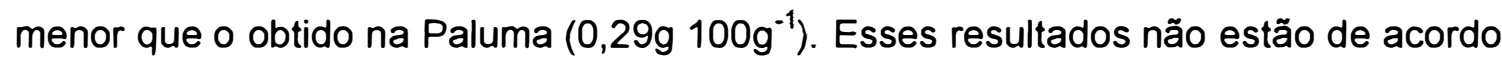
com os resultados obtidos por Lima et al. (1988); Eles encontraram valores de 0,36 a $0,58 \mathrm{~g} 100 \mathrm{~g}^{-1}$ nos frutos do Pedro Sato.

Os resultados obtidos para as duas variedades estudadas foram menores do que os obtidos por Esteves et al. (1984a), que encontraram valores que variaram de 0,6 a $1,0 \mathrm{~g} 100 \mathrm{~g}^{-1}$ nas frutas das variedades Brune Vermelha, IAC-4 e São José Piriforme; Pereira \& Martinez JR (1986), Medina et al. (1978) e Passos et al. (1979)

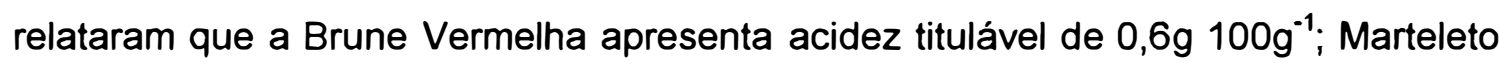

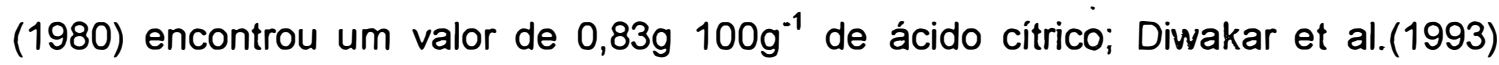
avaliando 3 variedades de goiaba, detectaram que a acidez variou de 0,54 a 0,49g $100 \mathrm{~g}^{-1}$; Pinheiro et al (1984) avaliaram a Pirassununga Vermelha e encontraram teor

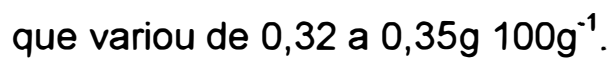


É desejável que as frutas destinadas à industrialização possuam um alto teor de acidez, pois menor será a quantidade de ácido cítrico a ser adicionada; esta redução é um fator de economia para a indústria, desde que as frutas sejam utilizadas em produtos com acidez reduzida ou ainda para o consumo ao natural.

Os valores de $\mathrm{pH}$ encontrados na variedade Paluma e na Pedro Sato foram 3,63 e 3,85 , respectivamente. Comparando-se esses valores com os da acidez total titulável, podemos observar que a Paluma apresentou pH menor; logo, sua acidez é

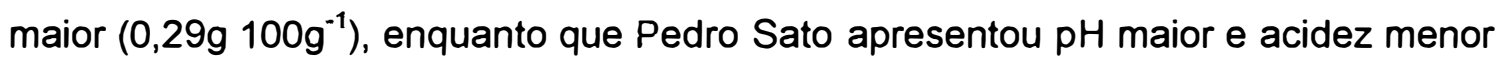
$\left(0,21 \mathrm{~g} 100 \mathrm{~g}^{-1}\right)$.

Segundo Nascimento et al.(1991), a Paluma madura apresentou pH de 4,20, valor maior que o encontrado neste trabalho. Esta diferença pode ser justificada pela diferença de clima, do solo e dos tratos culturais, já que foram cultivadas em regiões diferentes.

O estudo de sólidos solúveis é importante pois quase todos esses compostos dissolvidos nas frutas são açúcares, de grande importância no processamento industrial. Sob esse aspecto, para a indústria, elevados percentuais deste elemento na matéria-prima, principalmente nos produtos obtidos a partir da polpa, como o doce em pasta, suco, néctar e geléia, implicam em menor adição de açúcares, menor tempo de concentração, menor consumo de energia e maior rendimento do produto, o que resulta em maior economia no processamento. Com relação a quantidade de sólidos solúveis, observa-se que as médias apresentadas na Tabela 2, para as variedades Paluma e Pedro Sato apresentaram valores de 10 e $11^{\circ} \mathrm{Brix}$ respectivamente. São valores altos, portanto as variedades em estudo são economicamente promissoras para a indústria.

Dias (1983) mencionou a importância de sólidos solúveis para a goiaba, seja no processamento industrial, seja no comércio do fruto ao natural. Em ambos os casos, são desejáveis percentuais elevados desses componentes.

Com base nessas informações, pode-se dizer que as variedades Paluma e Pedro Sato são promissoras tanto para o consumo ao natural como para a industrialização.

Darezzo \& Durigan (1995), encontraram para a variedade Paluma $9,3^{\circ}$ Brix, Lima et al. (1998) encontraram para a Pedro Sato valores que variaram de 8,9 a 
$10,85^{\circ}$ Brix. Comparando estes valores com os encontrados nesse experimento, (Tabela 2), pode-se observar que os teores de sólidos solúveis detectados nesse trabalho foram maiores que os encontrados por estes autores.

Para frutas de outras variedades foram encontrados teores que variaram de 6,88 a $10,52^{\circ}$ Brix. Mais uma vez nota-se que os valores encontrados para as variedades em estudo são próximos dos teores mais altos de Brix encontrados nessas variedades estudadas.

O teor de vitamina C para a variedade Paluma $\left(119,29 \mathrm{mg} 100 \mathrm{~g}^{-1}\right)$ obtido neste trabalho, foi menor que os valores encontrados por Darezzo \& Durigan (1995), que encontraram valor médio de $168 \mathrm{mg} 100 \mathrm{~g}^{-1}$. Esta diferença pode ocorrer devido a diferença de solo utilizada no plantio, a forma do cultivo e as condições climáticas. Já a variedade Pedro Sato apresentou valor menor que o da Paluma (114,56mg $\left.100 \mathrm{~g}^{-1}\right)$; mas mesmo assim, está de acordo com Lima et al. (1998), que encontraram para a Pedro Sato um teor de vitamina C que variou de 94,26 a $137,19 \mathrm{mg}_{100 \mathrm{~g}^{-1}}$.

De modo geral, os teores de vitamina $C$ encontrados neste trabalho foram menores que aqueles encontrados por outros autores, estudando outras variedades. Esteves et al. (1994b) estudaram 6 variedades e dentre essas, a fruta da IAC-4 é a que mais se destacou, apresentando o maior teor de vitamina C $371,90 \mathrm{mg} 100 \mathrm{~g}^{-1}$. A variedade Brune Vermelha foi estudada por vários autores: Pereira \& Martinez (1986), Medina et al (1978), Esteves et al. (1984b) e Passos et al. (1979), sendo encontrada nos frutos valores de ácido ascórbico que variaram de 18 a $215 \mathrm{mg} 100 \mathrm{~g}^{-1}$. Marteleto (1980) encontrou na variedade Riverside Vermelha um teor de $147 \mathrm{mg}^{100 \mathrm{~g}^{-1}}$. Em frutas da variedade Allahabad Safeda, Diwakar (1993), detectou 110,37mg $100 \mathrm{~g}^{-1}$. Pinheiro et al. (1984) determinaram que a variedade Pirassununga Vermelha, após compararem com as frutas de outras variedades, foi a que apresentou as melhores caracteristicas para a industrialização, com teor de vitamina C que variou de 154 a $164 \mathrm{mg} 100 \mathrm{~g}^{-1}$.

Sabe-se que a matéria-prima que apresenta uma alta porcentagem de vitamina $\mathrm{C}$ será desejada pelas indústrias, porque apesar do tratamento térmico e tempo de armazenamento ao qual o produto será submetido, o produto final apresentará um alto teor de vitamina $\mathrm{C}$. É preciso ainda analisar os teores de acidez e de sólidos solúveis e as características da fruta (cor da polpa, sabor, tamanho e seu 
rendimento) - estes elementos juntos vão determinar o destino mais apropriado para a fruta: purê, compota ou consumo ao natural.

De acordo com Lemos et al. (1995), as diferenças entre as condições climáticas dos locais de cultivo, a adubação e os tratos dispensados à cultura são fatores que geraram variações nos teores de ácido cítrico e ácido ascórbico, encontrados em frutos de um mesmo cultivar, por diferentes autores.

\subsection{Análises químicas dos néctares, comuns e dietéticos, das variedades Paluma e Pedro Sato.}

Observando as tabelas 3, 4, 5 e 6, foi possível constatar que os tratamentos diferiram entre si ao nível de $1 \%$ de significância. Observa-se que os teores médios de vitamina $C$ dos néctares obtidos pelo tratamento 4 diferiram significativamente dos teores médios obtidos pelos tratamentos 1,2 e 3 , e dentre esses 0 tratamento 1 diferiu significativamente dos tratamentos 2 e 3, que não diferiram significativamente entre si. As médias do tratamento 4 diferiram dos outros, pois foi adicionado em suas formulações ácido ascórbico, portanto, a diferença estatística significativa entre o tratamento 4 e os demais tratamentos já era esperada. Os valores médios do tratamento 1 diferiram estatisticamente dos valores médios dos outros tratamentos, devido ao seu armazenamento refrigerado que contribuiu para a menor redução no teor de ácido ascórbico (que os tratamentos 2 e 3). Sabe-se que temperaturas baixas contribuem para a menor redução do teor de ácido ascórbico, pois diminuem a velocidade da reação, que é responsável pela transformação da vitamina $\mathrm{C}$ por meio da oxidação irreversível do ácido dehidroascórbico em ácido 2,3 dicetogulônico (Franco, 1994).

Em relação ao período de armazenamento, houve redução estatisticamente significativa do ácido ascórbico, ao nível de 1\%. Como o ácido ascórbico é muito sensível, apesar do vácuo criado na hora do fechamento das latas, uma pequena quantidade de oxigênio que ainda possa ter restado dentro da embalagem pode ter contribuído para a oxidadação deste componente, sem se descartar a temperatura ambiente à qual os tratamentos foram submetidos. 
Quanto à interação entre tratamento e tempo, houve diferença estatística significativa ao nível de $1 \%$ para os néctares comuns processados com purê das variedades Paluma e Pedro Sato e para os néctares dietéticos com Pedro Sato; quanto aos néctares dietéticos processados com puré da Paluma, esses apresentaram interação entre tratamento e tempo significativa estatisticamente, ao nível de $5 \%$.

Os resultados médios do tratamento 1 obtidos nos experimentos, apresentados nas Tabelas 3, 4, 5 e 6, apresentaram perdas de vitamina $C$ que variaram de 9 a 13\%; esta redução está de acordo com os resultados obtidos por Oliva et al. (1996), que armazenaram néctares de acerola durante 180 dias sob refrigeração $\left(8^{\circ} \mathrm{C}\right)$ e encontraram perdas de $5,76 \%$ a $9,80 \%$. Eleutério (1998) verificou que a geléia de acerola teve perda de $13,76 \%$, após 180 dias de armazenamento, a $7^{\circ} \mathrm{C}$. Segundo Bobbio \& Bobbio (1989), a estabilidade da vitamina C aumenta em temperaturas mais baixas.

Ainda observando as Tabelas 3, 4, 5 e 6, nota-se que os tratamentos 2 e 3 apresentaram redução média de $29 \%$ no armazenamento em temperatura ambiente, estando de acordo com Oliva et al. (1996); eles tiveram perdas de $27 \%$ de ácido ascórbico no armazenamento em temperatura ambiente de 180 dias, de néctares de acerola. Quanto ao tratamento 4, foi observada queda no teor de ácido ascórbico de $20 \%$. Os tratamentos 2 e 3 apresentaram redução maior de vitamina C, pois o armazenamento foi a temperatura ambiente e sabe-se que quanto maior a temperatura, maior será a perda do ácido ascórbico. O tratamento 4 apresentou perda pequena de ácido ascórbico quando comparada com os outros produtos que também foram armazenados em temperatura ambiente. Essa perda pode ser atribuída à adição de ácido ascóbico, que também tem a função de antioxidante.

O tratamento 4 foi aquele que recebeu adição de ácido ascórbico e apresentou teores altos de ácido ascórbico no final do armazenamento, indicando que a revitaminação foi eficiente.

Os tratamentos 2 e 3 (dos néctares dietéticos), da variedade Pedro Sato, apresentaram, ao final do armazenamento, 23,53mg $100 \mathrm{~g}^{-1}$ de ácido ascórbico. Foram os teores mais baixos encontrados, quando comparados com as outras formulações. Fonseca e Nogueira (1968) encontraram em néctares de goiaba 
$11,25 \mathrm{mg} 100 \mathrm{~g}^{-1}$ e $23,22 \mathrm{mg} 100 \mathrm{~g}^{-1}$ de vitamina C. Concluiram que estes valores poderiam ser maiores. Neste trabalho, os maiores teores de vitamina $C$ (no final do armazenamento) foram encontrados no tratamento 1 , com néctar da variedade

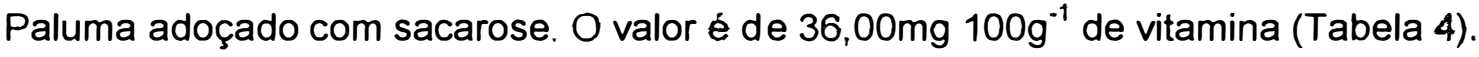

De modo geral, os néctares dietéticos apresentaram teores de vitamina $C$ menores que aqueles adoçados com sacarose; é possivel que tenha ocorrido alguma variação no processamento, uma vez que os néctares foram processados em datas diferentes, e a vitamina $\mathrm{C}$ é muito sensível à luz e às altas temperaturas.

Das análises quimicas, a de vitamina C é uma das mais importantes. Sua presença nos alimentos indica que outros nutrientes foram preservados, constituindose num indicador de qualidade e componente vital para a saúde do organismo humano.

Tabela 3 - Teores de ácido ascórbico (mg ácido ascórbico $100 \mathrm{~g}^{-1}$ ) dos néctares comuns de goiaba, da variedade Paluma, durante o período de armazenamento.

\begin{tabular}{|c|c|c|c|c|}
\hline \multirow[b]{2}{*}{ Tempo (dias) } & \multicolumn{4}{|c|}{ TRATAMENTOS } \\
\hline & $\mathrm{T} 1$ & $\mathrm{~T} 2$ & T3 & $\mathrm{T} 4$ \\
\hline 0 & 40,00 & 40,00 & 40,00 & 62,86 \\
\hline 30 & 39,28 & 34,28 & 34,28 & 57,14 \\
\hline 60 & 38,78 & 34,28 & 34,28 & 57,14 \\
\hline 90 & 37,81 & 33,34 & 33,34 & 56,35 \\
\hline 120 & 37,31 & 30,00 & 31,28 & 54,25 \\
\hline 150 & 36,28 & 29,41 & 30,00 & 52,18 \\
\hline 180 & 36,00 & 28,57 & 29,00 & 49,24 \\
\hline MÉDIAS & $37,92^{8}$ & $32,84^{C}$ & $33,17^{C}$ & $55,59^{A}$ \\
\hline F (tratamento) & $3406,54^{\star \star}$ & & & \\
\hline$F$ (tempo) & $186,06^{\star \star}$ & & & \\
\hline$F($ trat*tempo) & $8,07^{\star \star}$ & & & \\
\hline
\end{tabular}


Tabela 4 - Teores de ácido ascórbico (mg ácido ascórbico $100 \mathrm{~g}^{-1}$ ) dos néctares comuns de goiaba, da variedade Pedro Sato, durante o período de armazenamento.

\begin{tabular}{|c|c|c|c|c|}
\hline \multirow[b]{2}{*}{ Tempo (dias) } & \multicolumn{4}{|c|}{ TRATAMENTOS } \\
\hline & T1 & T2 & T3 & T4 \\
\hline 0 & 41,00 & 41,25 & 39,78 & 62,93 \\
\hline 30 & 38,71 & 33,71 & 33,71 & 57,75 \\
\hline 60 & 38,59 & 33,94 & 34,00 & 56,66 \\
\hline 90 & 37,32 & 31,67 & 32,73 & 56,87 \\
\hline 120 & 36,74 & 30,00 & 31,78 & 55,28 \\
\hline 150 & 36,24 & 29,41 & 30,61 & 52,72 \\
\hline 180 & 35,59 & 26,84 & 27,49 & 46,78 \\
\hline MÉDIAS & $37,74^{8}$ & $32,34^{c}$ & $32,87^{C}$ & $55,57^{A}$ \\
\hline F (tratamento) & $3887,90^{\star \star}$ & & & \\
\hline F (tempo) & $204,32^{\star \star}$ & & & \\
\hline$F$ (trattempo) & $10,29^{\star \star}$ & & & \\
\hline
\end{tabular}

Tabela 5 - Teores de ácido ascórbico (mg ácido ascórbico $100 \mathrm{~g}^{-1}$ ) dos néctares dietéticos de goiaba, da variedade Paluma, durante o período de armazenamento.

$\begin{array}{ccccc} & & \text { TRATAMENTOS } & \\ \text { Tempo (dias) } & \text { T1 } & \text { T2 } & \text { T3 } & \text { T4 } \\ 0 & 35,32 & 32,77 & 32,77 & 57,14 \\ 30 & 34,37 & 30,77 & 31,25 & 56,25 \\ 60 & 34,75 & 30,09 & 30,77 & 56,25 \\ 90 & 33,75 & 29,86 & 30,30 & 54,54 \\ 120 & 32,80 & 28,99 & 28,99 & 52,18 \\ 150 & 32,57 & 26,05 & 27,11 & 51,36 \\ 180 & 31,97 & 24,44 & 24,59 & 47,82 \\ \text { MÉDIAS } & 33,65^{B} & 28,99^{\mathrm{C}} & 29,39^{\mathrm{C}} & 53,65^{\mathrm{A}} \\ \text { F (tratamento) } & 2332,07^{\star \star} & & & \\ \text { F (tempo) } & 62,31^{\star \star} & & & \\ \text { F (trat*tempo) } & 2,59^{\star} & & & \end{array}$

$* *=$ significativo ao nivel de $1 \%$.

*=significativo ao nivel de $5 \%$.

médias com a mesma letra, no sentido horizontal, nåo diferem entre si, ao nivel de $5 \%$. 
Tabela 6 - Teores de ácido ascórbico ( $\mathrm{mg}$ ácido ascórbico $\left.100 \mathrm{~g}^{-1}\right)$ dos néctares dietéticos de goiaba, da variedade Pedro Sato, durante o período de armazenamento.

\begin{tabular}{|c|c|c|c|c|}
\hline \multirow[b]{2}{*}{ Tempo (dias) } & \multicolumn{4}{|c|}{ TRATAMENTOS } \\
\hline & T1 & T2 & $T 3$ & T4 \\
\hline 0 & 35,29 & 34,28 & 30,77 & 56,41 \\
\hline 30 & 34,28 & 30,77 & 29,41 & 52,94 \\
\hline 60 & 34,27 & 29,41 & 29,41 & 52,92 \\
\hline 90 & 34,21 & 29,41 & 29,41 & 51,43 \\
\hline 120 & 33,41 & 28,57 & 28,99 & 49,26 \\
\hline 150 & 32,92 & 26,05 & 28,57 & 47,10 \\
\hline 180 & 32,10 & 23,53 & 23,53 & 47,10 \\
\hline MÉDIAS & $33,78^{8}$ & $28,86^{C}$ & $28,58^{C}$ & $51,02^{A}$ \\
\hline F (tratamento) & $1551,71^{\star \star}$ & & & \\
\hline$F$ (tempo) & $47,35^{\star \star}$ & & & \\
\hline$F$ (trat*tempo) & $3,97^{\star \star}$ & & & \\
\hline
\end{tabular}

Pela análise de variância, com aplicação do teste $F$, constatou-se que existe diferença significativa, ao nível de $1 \%$, na variação do teor de ácido ascórbico dos néctares comuns (Paluma e Pedro Sato) e dietéticos (Paluma e Pedro Sato), na interação entre tratamento e tempo.

Pela análise de regressão, as função de melhor ajuste dos resultados dos teores de ácido ascórbico na interação entre tratamento e período de armazenamento estão representadas pelas equações lineares (1), (2), (3) e (4) referentes aos tratamentos $1,2,3$ e 4 respectivamente dos néctares comuns da Paluma:

$$
\begin{aligned}
& \text { T1 } y=39,980021-0,0232024 . x{ }^{\star \star} R^{2}=83 \%(1) \\
& \text { T2 } y=38,016071-0,0575119 . x{ }^{\star \star} R^{2}=88 \%(2) \\
& \text { T3 } y=37,944642-0,0530833 . x{ }^{\star \star} R^{2}=88 \%(3) \\
& \text { T4 } y=61,343393-0,0638631 . x{ }^{\star \star} R^{2}=91 \%(4)
\end{aligned}
$$

Em que y = conteúdo de ácido ascórbico

$$
x=\text { tempo de armazenamento (dias) }
$$


As representações gráficas dos teores de ácido ascórbico dos tratamentos dos néctares comuns da Paluma podem ser vistos na Figura 7.

Em relação aos tratamentos 1, 2, 3 e 4, dos néctares comuns da Pedro Sato, as equações estão representadas pelas equações (5), (6), (7) e (8) respectivamente:

$$
\begin{array}{r}
\text { T1 } y=40,062857-0,0250085 . x^{\star \star} R^{2}=81 \%(5) \\
\text { T2 } y=38,224642-0,0653690 . x^{\star \star} R^{2}=84 \%(6) \\
\text { T3 } y=37,721607-0,0538988 . x{ }^{\star \star} R^{2}=86 \%(7) \\
\text { T4 } y=61,986786-0,0712976 . x{ }^{\star \star} R^{2}=86 \%(8) \\
\text { Em que } y=\text { conteúdo de ácido ascórbico } \\
x=\text { tempo de armazenamento (dias) }
\end{array}
$$

As representações gráficas dos teores de ácido ascórbico dos tratamentos dos néctares comuns da Pedro Sato podem ser vistos na Figura 8.

Em relação aos tratamentos 1, 2, 3 e 4, dos néctares dietéticos da Paluma, as equações estão representadas pelas equações (9), (10), (11) e (12) respectivamente:

$$
\begin{array}{r}
\text { T1 } y=35,321429-0,0185714 . x{ }^{\star \star} R^{2}=94 \%(9) \\
\text { T2 } y=32,801786-0,0422976 . x{ }^{\star \star} R^{2}=92 \%(10) \\
\text { T3 } y=33,105536-0,0412202 . x{ }^{\star \star} R^{2}=92 \%(11) \\
\text { T4 } y=58,128393-0,0497917 . x{ }^{\star \star} R^{2}=91 \%(12) \\
\text { Em que } y=\text { conteúdo de ácido ascórbico } \\
x=\text { tempo de armazenamento (dias) }
\end{array}
$$

As representações gráficas dos teores de ácido ascórbico dos tratamentos dos néctares dietéticos da Paluma podem ser vistos na Figura 9.

Em relação aos tratamentos 1, 2, 3 e 4, dos néctares dietéticos da Pedro Sato, as equações estão representadas pelas equações (13), (14), (15) e (16) respectivamente: 

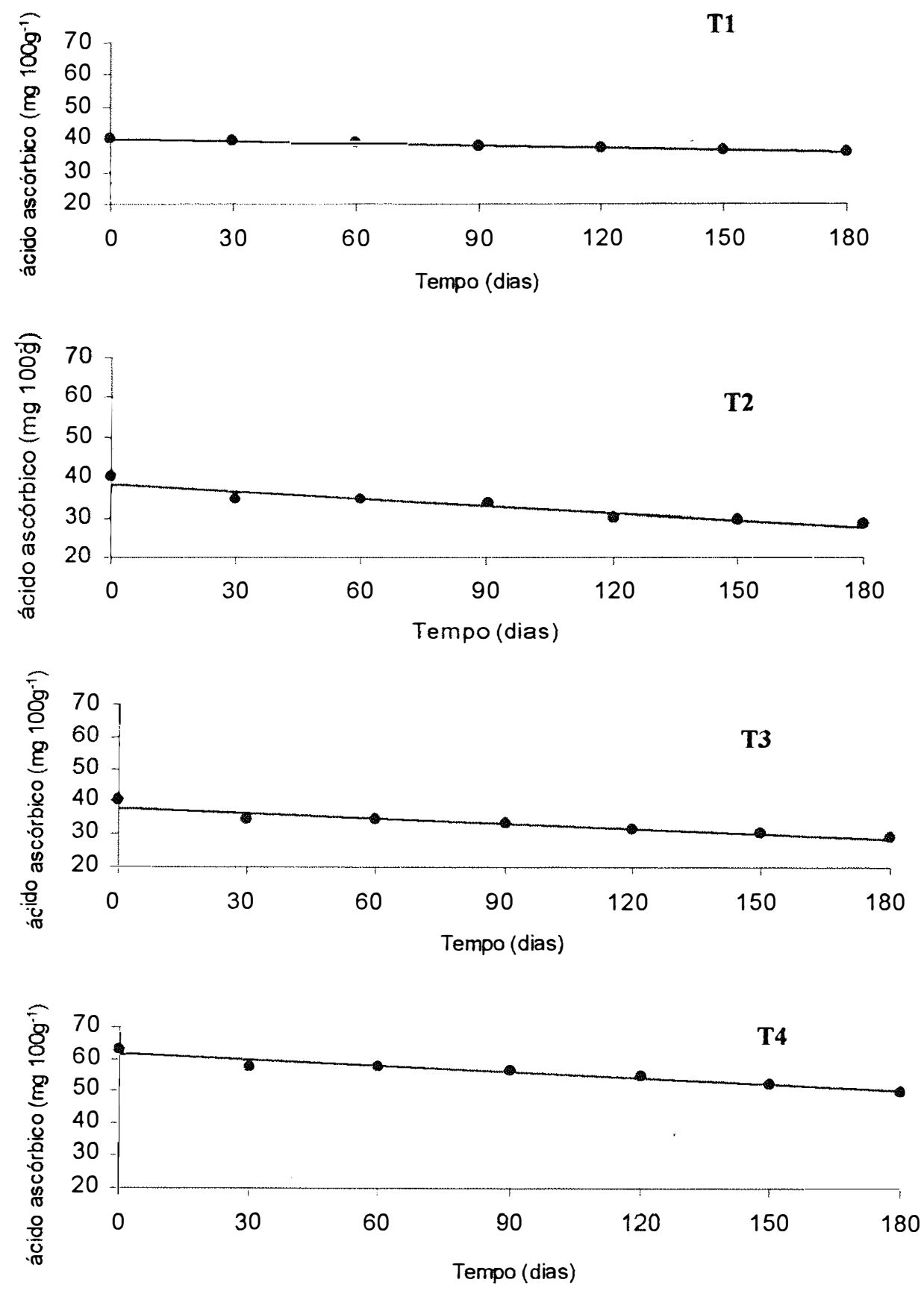

Figura 7 - Teores de ácido ascórbico presentes nos néctares comuns de goiaba, variedade Paluma, obtidos dos tratamentos, no período de 180 dias. 

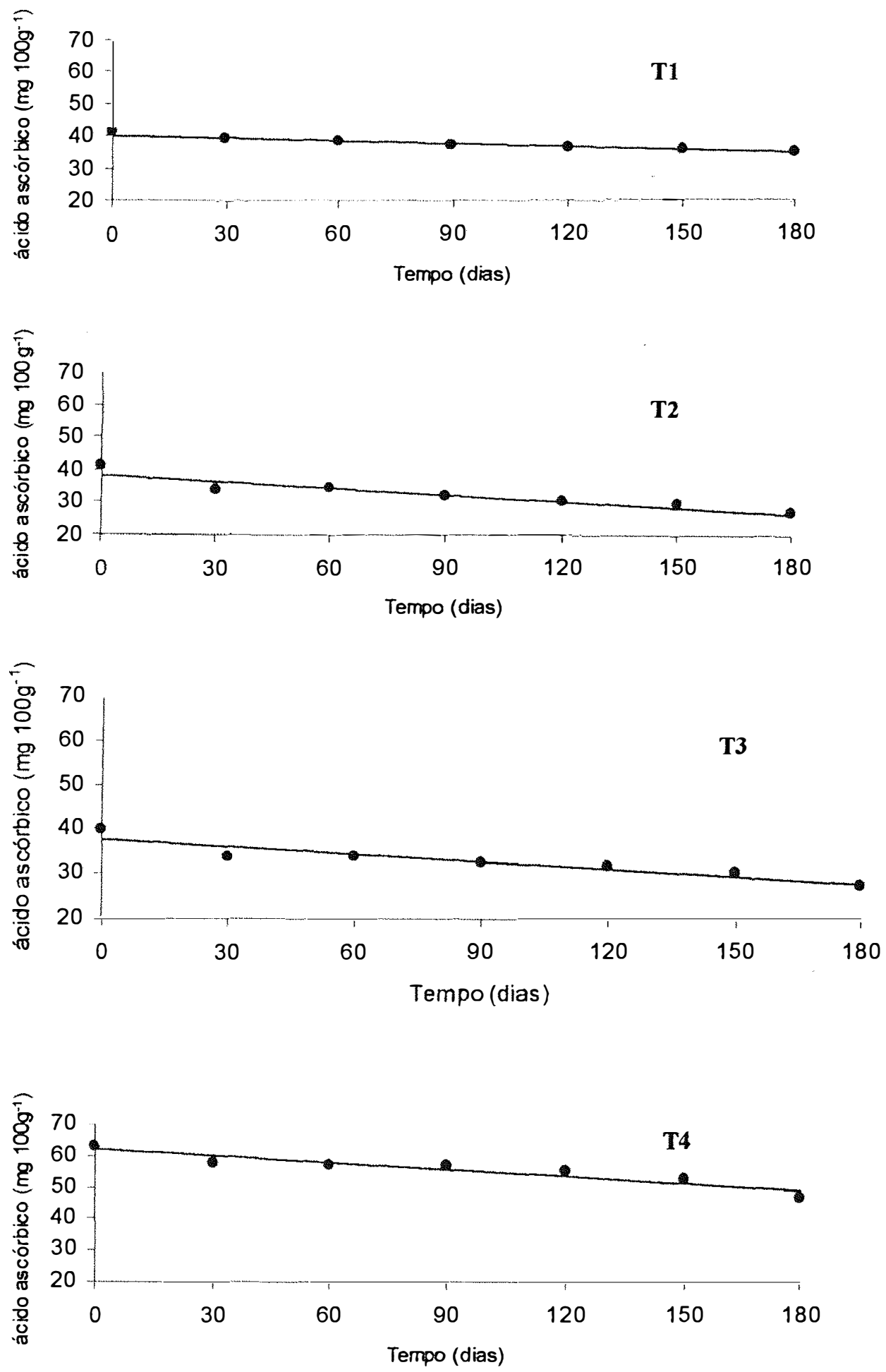

Figura 8 - Teores de ácido ascórbico presentes nos néctares comuns de goiaba, variedade Pedro Sato, obtidos dos tratamentos, no período de 180 dias. 

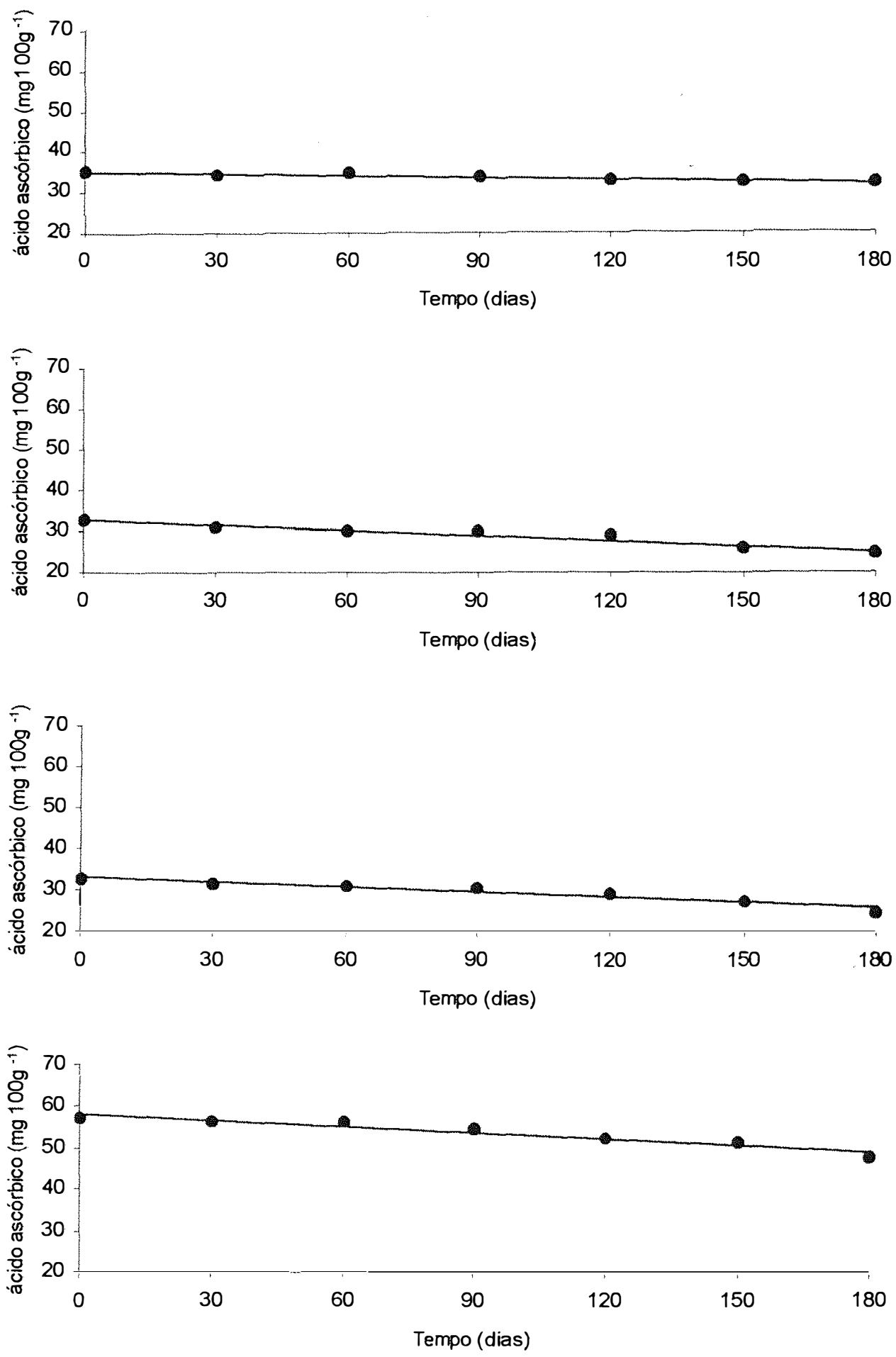

Figura 9 - Teores de ácido ascórbico presentes nos néctares dietéticos de goiaba, da variedade Paluma, obtidos dos tratamentos, no período de 180 dias. 


$$
\begin{array}{r}
\text { T1 } y=35,029286-0,0161121 . x{ }^{\star \star} R^{2}=84 \%(13) \\
\text { T2 } y=33,416785-0,0506309 . x{ }^{\star \star} R^{2}=92 \%(14) \\
\text { T3 } y=31,136429-0,0283571 . x{ }^{\star \star} R^{2}=72 \%(15) \\
\text { T4 } y=55,659107-0,0515060 . x{ }^{\star \star} R^{2}=95 \%(16) \\
\text { Em que } y=\text { conteúdo de ácido ascórbico } \\
x=\text { tempo de armazenamento (dias) }
\end{array}
$$

As representações gráficas dos teores de ácido ascórbico nos tratamentos dos néctares dietéticos da Pedro Sato podem ser vistos na Figura 10.

Pelas Tabelas 7, 8, 9 e 10 pode-se observar as variações da acidez nos néctares comuns e dietéticos, das variedades Paluma e Pedro Sato. Nota-se que houve alterações nos teores da acidez para todos os tratamentos de ambas as variedades que foram significativas ao nivel de $1 \%$ de significância. Verifica-se que os teores médios de acidez, tanto para os produtos da Paluma como para os produtos de Pedro Sato, dos tratamentos 3 e 4 foram maiores que os valores dos tratamento 1 e 2 , pois estes dois últimos não receberam adição de sorbato de potássio nem de ácido ascórbico.

A redução de acidez neste ensaio pode ser atribuída à diminuição dos teores de ácido ascórbico, uma vez que faz parte da acidez total, e todos os produtos tiveram alterações significativas com o tempo de armazenamento.

Em relação às reduções de acidez, também foram significativas estatisticamente ao nivel de $1 \%$, e na interação entre tratamento e tempo. O tratamento 1 foi o que apresentou menor redução na acidez, acompanhando menor redução de ácido ascórbico durante $o$ armazenamento.

Esta diminuição de acidez com o armazenamento está de acordo com Bemiz (1984); ele relatou que no armazenamento de néctar de manga também houve queda da acidez. Novaes (1997) observou em néctar de morango comum e dietético, queda do teor de acidez com o armazenamento. Em contrapartida, Kalra e Tandon (1984), Okoli e Ezenweke (1990) e Baramanray et al. (1995), observaram em néctar de goiaba, suco de mamão e néctar de goiaba, respectivamente, aumento da acidez com o período de armazenamento. 

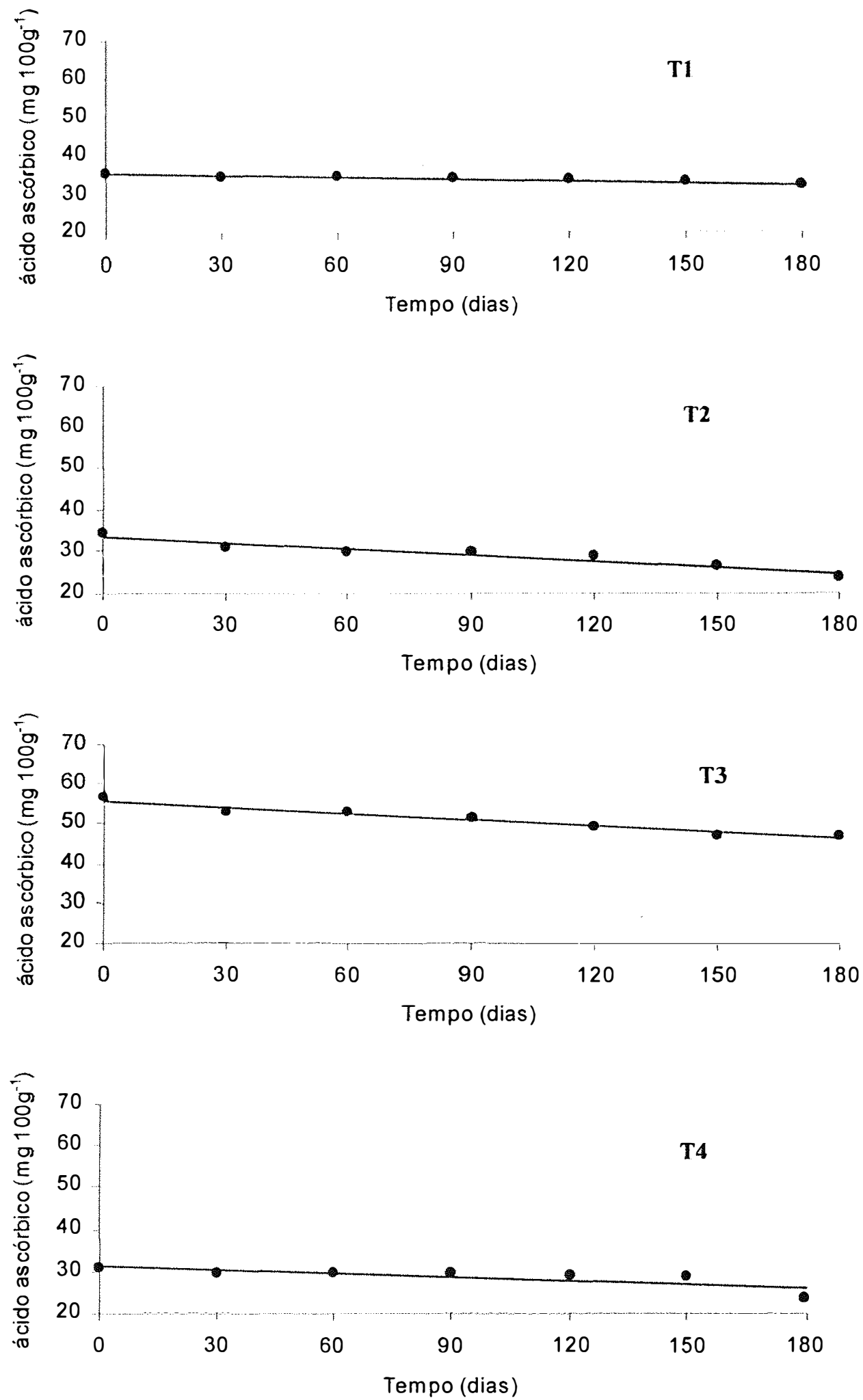

Figura 10 - Teores de ácido ascórbico presentes nos néctares dietéticos de goiaba, variedade Pedro Sato, obtidos dos tratamentos, no período de 180 dias. 
Cabe ressaltar que Okoli e Ezenweke (1990) processaram várias formulações de suco de mamão; uma delas armazenou a $10^{\circ} \mathrm{C}$, não tendo sido observado alteração significativa da acidez com o armazenamento.

Pela análise de variância, com aplicação do teste $F$, constatou-se que existe diferença significativa, ao nível de $1 \%$, na variação de acidez total dos néctares comuns (Paluma e Pedro Sato) e dietéticos (Paluma e Pedro Sato), na interação entre tratamento e tempo.

Pela análise de regressão, as função de melhor ajuste dos resultados dos teores de acidez total na interação entre tratamento e período de armazenamento estão representadas pelas equações lineares (17), (18), (19) e (20) referentes aos tratamentos 1, 2, 3 e 4 respectivamente dos néctares comuns da Paluma:

$$
\begin{aligned}
& \text { T1 } y=0,141054-0,0001387 . x{ }^{\star \star} R^{2}=86 \%(17) \\
& \text { T2 } y=0,143536-0,0001726 \cdot x{ }^{\star \star} R^{2}=97 \%(18) \\
& \text { T3 } y=0,225857-0,0003357 \cdot x{ }^{\star \star} R^{2}=98 \%(19) \\
& \text { T4 } y=0,238839-0,0002601 . x{ }^{\star \star} R^{2}=93 \%(20)
\end{aligned}
$$

$$
\text { Em que } \begin{aligned}
y & =\text { conteúdo de acidez } \\
x & =\text { tempo de armazenamento (dias) }
\end{aligned}
$$

\begin{tabular}{|c|c|c|c|c|}
\hline \multirow[b]{2}{*}{ Tempo (dias) } & \multicolumn{4}{|c|}{ TRATAMENTOS } \\
\hline & $\mathrm{T} 1$ & $\mathrm{~T} 2$ & T3 & $\mathrm{T} 4$ \\
\hline 0 & 0,143 & 0,143 & 0,226 & 0,245 \\
\hline 30 & 0,140 & 0,140 & 0,220 & 0,230 \\
\hline 60 & 0,130 & 0,134 & 0,207 & 0,215 \\
\hline 90 & 0,127 & 0,129 & 0,191 & 0,216 \\
\hline 120 & 0,120 & 0,120 & 0,187 & 0,209 \\
\hline 150 & 0,119 & 0,118 & 0,180 & 0,198 \\
\hline 180 & 0,122 & 0,114 & 0,163 & 0,196 \\
\hline MÉDIAS & $0,129^{C}$ & $0,128^{C}$ & $0,196^{B}$ & $0,215^{\mathrm{A}}$ \\
\hline F (tratamento) & $2062,4^{\star \star}$ & & & \\
\hline$F($ tempo) & $231,45^{\star \star}$ & & & \\
\hline$F\left(\right.$ trat $^{\star}$ tempo) & $11,61^{\star \star}$ & & & \\
\hline
\end{tabular}

As representações gráficas dos teores de acidez total dos tratamentos dos néctares comuns da Paluma podem ser vistos na Figura 11.

Tabela 7 - Teores de acidez total ( $\mathrm{g}$ de ácido cítrico $100 \mathrm{~g}^{-1}$ ) dos néctares comuns de goiaba, da variedade Paluma, durante o período de armazenamento. 
Tabela 8 - Teores de acidez total ( $\mathrm{g}$ de ácido cítrico $100 \mathrm{~g}^{-1}$ ) dos néctares comuns de goiaba, da variedade Pedro Sato, durante o período de armazenamento.

\begin{tabular}{|c|c|c|c|c|}
\hline \multirow[b]{2}{*}{ Tempo (dias) } & \multicolumn{4}{|c|}{ TRATAMENTOS } \\
\hline & T1 & T2 & T3 & T4 \\
\hline 0 & 0,145 & 0,145 & 0,218 & 0,245 \\
\hline 30 & 0,145 & 0,143 & 0,214 & 0,233 \\
\hline 60 & 0,138 & 0,140 & 0,208 & 0,221 \\
\hline 90 & 0,136 & 0,142 & 0,196 & 0,215 \\
\hline 120 & 0,136 & 0,120 & 0,182 & 0,210 \\
\hline 150 & 0,128 & 0,117 & 0,175 & 0,203 \\
\hline 180 & 0,124 & 0,112 & 0,161 & 0,192 \\
\hline MÉDIAS & $0,136^{C}$ & $0,131^{D}$ & $0,193^{B}$ & $0,217^{A}$ \\
\hline F (tratamento) & $5112,74^{\star \star}$ & & & \\
\hline F (tempo) & $367,02^{\star \star}$ & & & \\
\hline$F$ (trat*tempo) & $19,72^{\star \star}$ & & & \\
\hline
\end{tabular}

** =significativo ao nivel de $1 \%$.

médias com a mesma letra, no sentido horizontal, não diferem entre si, ao nível de $5 \%$.

Tabela 9 - Teores de acidez total ( $\mathrm{g}$ de ácido cítrico $100 \mathrm{~g}^{-1}$ ) dos néctares dietéticos de goiaba, da variedade Paluma, durante o período de armazenamento.

\begin{tabular}{|c|c|c|c|c|}
\hline \multirow[b]{2}{*}{ Tempo (dias) } & \multicolumn{4}{|c|}{ TRATAMENTOS } \\
\hline & T1 & $T 2$ & T3 & T4 \\
\hline 0 & 0,143 & 0,142 & 0,226 & 0,245 \\
\hline 30 & 0,140 & 0,140 & 0,216 & 0,230 \\
\hline 60 & 0,130 & 0,134 & 0,206 & 0,215 \\
\hline 90 & 0,126 & 0,128 & 0,191 & 0,215 \\
\hline 120 & 0,120 & 0,119 & 0,186 & 0,209 \\
\hline 150 & 0,119 & 0,118 & 0,180 & 0,198 \\
\hline 180 & 0,122 & 0,114 & 0,163 & 0,196 \\
\hline MÉDIAS & $0,129^{C}$ & $0,128^{C}$ & $0,195^{B}$ & $0,215^{A}$ \\
\hline$F$ (tratamento) & $13980^{\text {th }}$ & & & \\
\hline$F($ tempo) & $770.0^{\star \star}$ & & & \\
\hline$F$ (trat»tempo) & $12,57^{\star \star}$ & & & \\
\hline
\end{tabular}

$\star \star=$ significativo ao nivel de $1 \%$.

médias com a mesma letra, no sentido horizontal, năo diferem entre si, ao nível de 5\%. 
Tabela 10 - Teores de acidez total (em g de ácido cítrico $100 \mathrm{~g}^{-1}$ ) dos néctares dietéticos de goiaba, da variedade Pedro Sato, durante 0 período de armazenamento.

\begin{tabular}{|c|c|c|c|c|}
\hline \multirow[b]{2}{*}{ Tempo (dias) } & \multicolumn{4}{|c|}{ TRATAMENTOS } \\
\hline & T1 & T2 & T3 & T4 \\
\hline 0 & 0,159 & 0,153 & 0,218 & 0,240 \\
\hline 30 & 0,153 & 0,151 & 0,211 & 0,236 \\
\hline 60 & 0,153 & 0,145 & 0,203 & 0,226 \\
\hline 90 & 0,145 & 0,136 & 0,199 & 0,218 \\
\hline 120 & 0,145 & 0,131 & 0,192 & 0,209 \\
\hline 150 & 0,135 & 0,123 & 0,183 & 0,198 \\
\hline 180 & 0,133 & 0,119 & 0,169 & 0,196 \\
\hline MÉDIAS & $0,146^{C}$ & $0,136^{D}$ & $0,196^{B}$ & $0,217^{A}$ \\
\hline F (tratamento) & $6021,8^{\star \star \star}$ & & & \\
\hline$F($ tempo) & $1269,63^{\star \star}$ & & & \\
\hline$F($ trat”tempo) & $29,16^{\star \star}$ & & & \\
\hline
\end{tabular}

**=significativo ao nivel de $1 \%$.

médias com a mesma letra, no sentido horizontal, não diferem entre si, ao nível de $5 \%$.

Em relação aos tratamentos 1, 2, 3 e 4, dos néctares comuns da Pedro Sato, as equações estão representadas pelas equações (21), (22), (23) e (24) respectivamente:

T1 $y=0,146607-0,0001179 . x{ }^{\star \star} R^{2}=93 \%(21)$
T2 $y=0,149393-0,0002036 . x{ }^{\star \star} R^{2}=86 \%(22)$
T3 $y=0,222768-0,0003292 . x{ }^{\star \star} R^{2}=97 \%(23)$
T4 $y=0,241071-0,0002714 . x{ }^{\star \star} R^{2}=97 \%(24)$

Em que $y=$ conteúdo de acidez

$x=$ tempo de armazenamento (dias)

As representações gráficas dos teores de acidez total dos tratamentos dos néctares comuns da Pedro Sato podem ser vistos na Figura 12.

Em relação aos tratamentos 1, 2, 3 e 4, dos néctares dietéticos da Paluma, as equações estão representadas pelas equações (25), (26), (27) e (28) respectivamente:

$$
\begin{aligned}
& \text { T1 } y=0,162268-0,0001601 . x{ }^{\star \star} R^{2}=92 \%(25) \\
& \text { T2 } y=0,162625-0,0002268 . x{ }^{\star \star} R^{2}=98 \%(26) \\
& \text { T3 } y=0,229821-0,0002607 . x{ }^{\star \star} R^{2}=96 \%(27) \\
& \text { T4 } y=0,243750-0,0002774 . x{ }^{\star \star} R^{2}=96 \%(28)
\end{aligned}
$$

Em que $y=$ conteúdo de acidez

$\mathrm{x}=$ tempo de armazenamento (dias) 

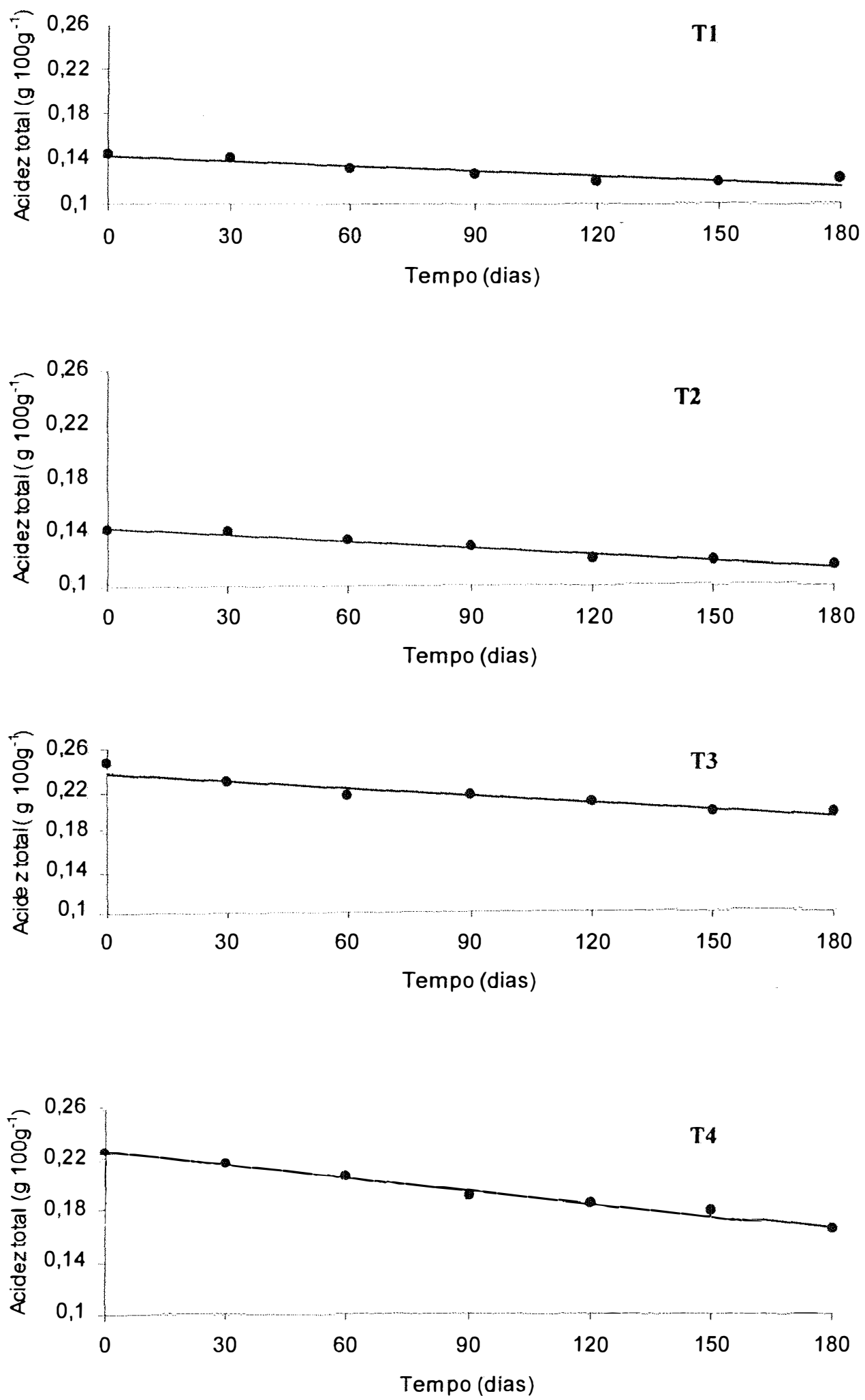

Figura 11 - Acidez total nos néctares comuns de goiaba, variedade Paluma, obtidos dos tratamentos, no período de 180 dias. 

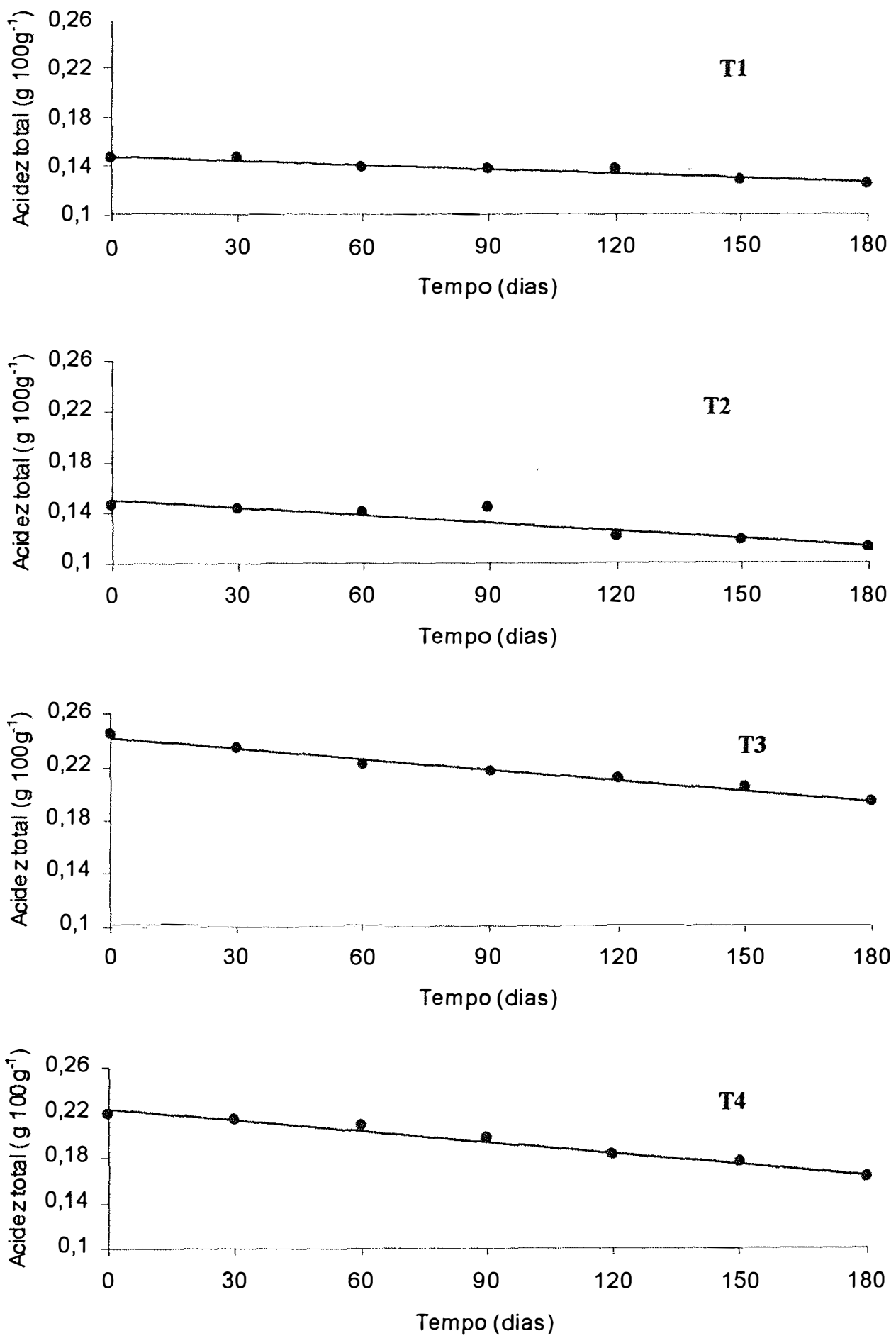

Figura 12 - Acidez total nos néctares comuns de goiaba, variedade Pedro Sato, obtidos dos tratamentos, no periodo de 180 dias. 
As representações gráficas dos teores de acidez total dos tratamentos dos néctares dietéticos da Paluma podem ser vistos na Figura 13.

Em relação aos tratamentos 1, 2, 3 e 4, dos néctares dietéticos da Pedro Sato, as equações estão representadas pelas equações (29), (30), (31) e (32) respectivamente:

$$
\begin{aligned}
& \text { T1 } y=0,159089-0,0001423 . x{ }^{\star \star} R^{2}=95 \%(29) \\
& \text { T2 } y=0,155250-0,0002036 \cdot x{ }^{\star \star} R^{2}=98 \%(30) \\
& \text { T3 } y=0,219482-0,0002530 . x{ }^{\star \star} R^{2}=97 \%(31) \\
& \text { T4 } y=0,241589-0,0002661 . x{ }^{\star \star} R^{2}=98 \%(32) \\
& \text { Em que } y=\text { conteúdo de acidez } \\
& x=\text { tempo de armazenamento (dias) }
\end{aligned}
$$

As representações gráficas dos teores de acidez total dos tratamentos dos néctares dietéticos da Pedo Sato podem ser vistos na Figura 14.

Com relação a análise dos resultados obtidos na avaliação do parâmetro Brix, pode-se observar nas Tabelas 11, 12, 13 e 14, que para ambas variedades as alterações ocorridas nos tratamentos, nos tempos e na interação entre tratamento e tempo, não foram estatísticamente significativas ao nivel de $5 \%$ de significância.

Ainda observando as tabelas, os resultados de sólidos solúveis não variaram entre os tratamentos, porque corrigiu-se o Brix em todas a formulações.

A estabilidade de sólidos solúveis durante o armazenamento, está de acordo com Souza Filho et al. (1992), Okoli \& Ezenweke (1990) e Novaes (1997), que também não observaram alterações de sólidos solúveis em xarope de caju, suco de mamão (armazenado a $10^{\circ} \mathrm{C}$ ) e néctar de morango, respectivamente. Os valores não estão de acordo com os encontrados por Baranmanray et al. (1995) que estudando variedades de goiaba, processaram néctares que foram armazenados em temperatura ambiente $\left(25^{\circ} \mathrm{C}\right)$ durante três meses. Detectaram aumento de sólidos solúveis com o tempo de armazenamento, em suas amostras, possivelmente causado pela conversão de polissacarídeos em açúcares simples, aumentando o Brix.

Já, Berniz (1984) processou néctares de manga e notou que durante o armazenamento houve aumento de sólidos solúveis. Okoli \& Ezenweke (1990), analisando suco de mamão armazenado em temperatura ambiente, notaram redução no teor de sólidos solúveis. 

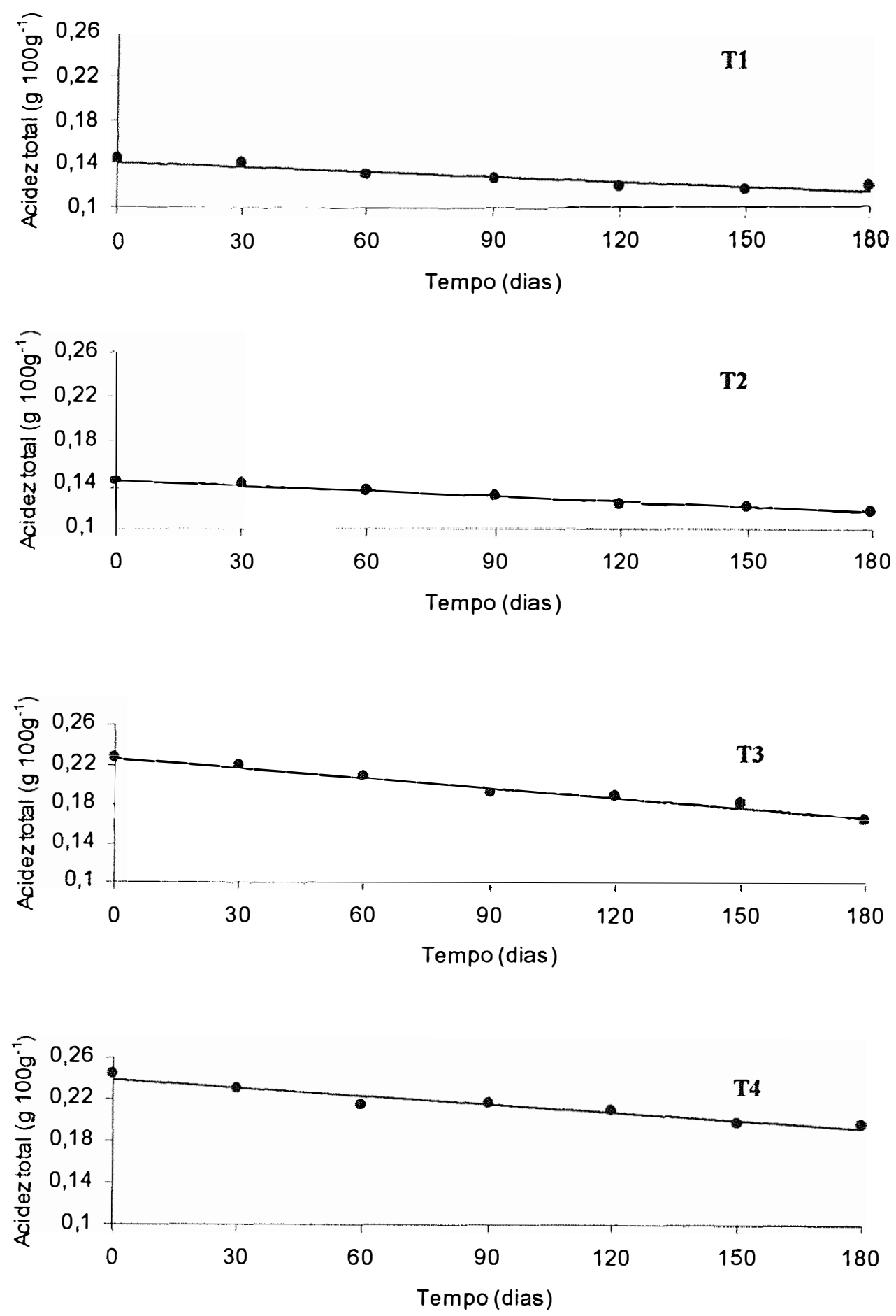

Figura 13 - Acidez total nos néctares dietéticos de goiaba; variedade Paluma, obtidos dos tratamentos, no período de 180 dias. 

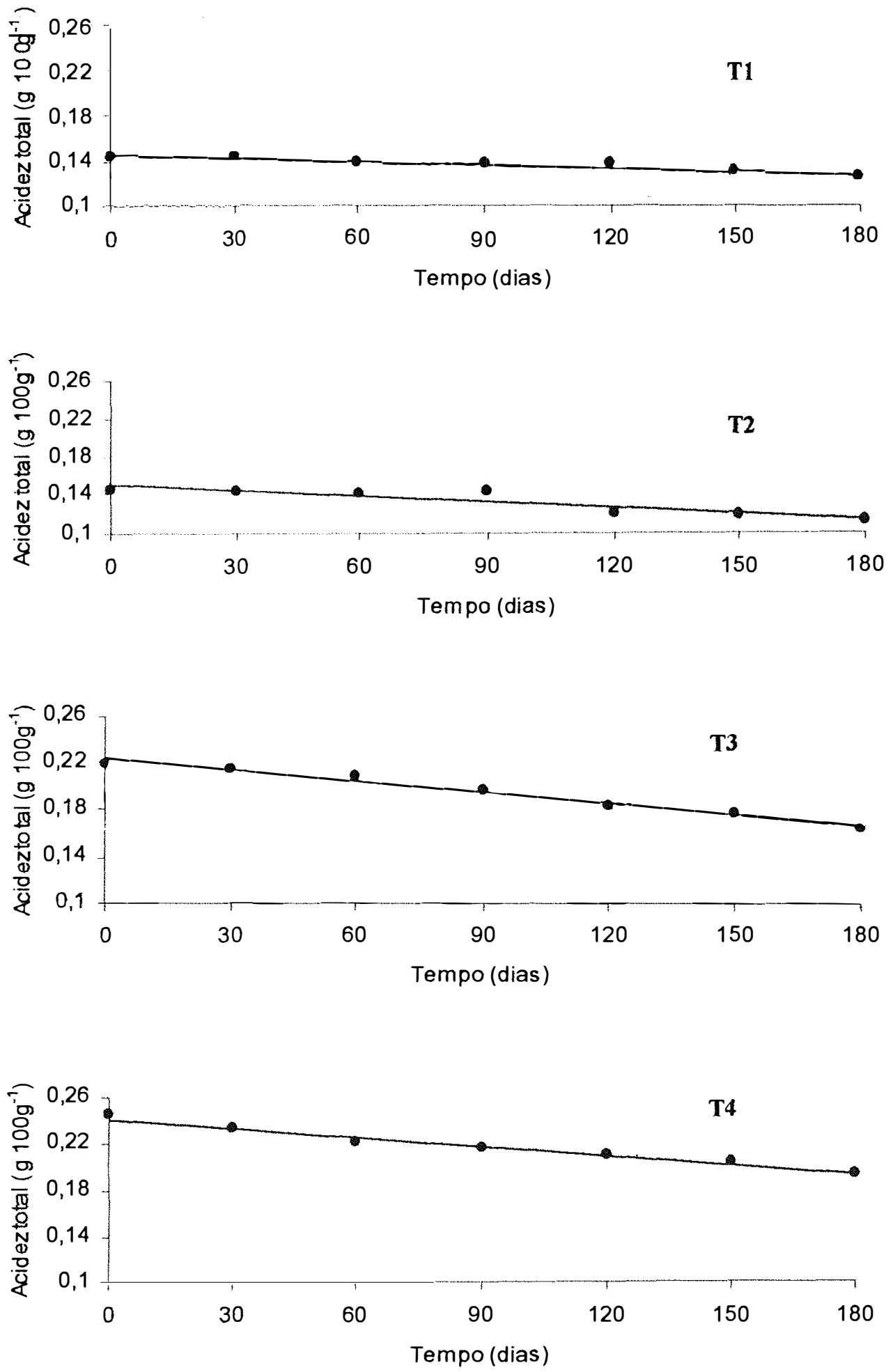

Figura 14 - Acidez total nos néctares dietéticos de goiaba, variedade Pedro Sato, obtidos dos tratamentos, no período de 180 dias. 
Tabela 11 - Teores de sólidos solúveis ( ${ }^{\circ}$ Brix) dos néctares comuns de goiaba, da variedade Paluma, durante o período de armazenamento.

\begin{tabular}{|c|c|c|c|c|}
\hline \multirow[b]{2}{*}{ Tempo (dias) } & \multicolumn{4}{|c|}{ TRATAMENTOS } \\
\hline & T1 & T2 & T3 & T4 \\
\hline 0 & 18,00 & 18,00 & 18,00 & 18,05 \\
\hline 30 & 18,25 & 18,00 & 18,25 & 18,10 \\
\hline 60 & 18,00 & 17,85 & 18,10 & 17,90 \\
\hline 90 & 18,00 & 18,05 & 18,05 & 18,05 \\
\hline 120 & 18,05 & 18,05 & 18,00 & 18,00 \\
\hline 150 & 17,95 & 17,95 & 18,00 & 17,95 \\
\hline 180 & 17,95 & 18,00 & 18,00 & 18,00 \\
\hline MÉDIAS & $18,03^{A}$ & $17,98^{A}$ & $18,06^{A}$ & $18,01^{A}$ \\
\hline $\mathrm{F}$ (tratamento) & $0,76^{\mathrm{ns}}$ & & & \\
\hline F (tempo) & $1,93^{\text {ns }}$ & & & \\
\hline F (trat*tempo) & $0,47^{\text {ns }}$ & & & \\
\hline
\end{tabular}

ns= nåo significativo.

médias com a mesma letra, no sentido horizontal, năo diferem entre si, ao nivel de $5 \%$.

Tabela 12 - Teores de sólidos solúveis ( ${ }^{\circ}$ Brix) dos néctares comuns de goiaba, da variedade Pedro Sato, durante o período de armazenamento.

\begin{tabular}{|c|c|c|c|c|}
\hline \multirow[b]{2}{*}{ Tempo (dias) } & \multicolumn{4}{|c|}{ TRATAMENTOS } \\
\hline & T1 & T2 & T3 & T4 \\
\hline 0 & 18,00 & 18,25 & 18,00 & 18,00 \\
\hline 30 & 18,35 & 18,05 & 18,20 & 18,25 \\
\hline 60 & 18,00 & 17,85 & 18,00 & 18,05 \\
\hline 90 & 18,00 & 18,15 & 18,00 & 18,30 \\
\hline 120 & 18,15 & 18,05 & 17,95 & 18,00 \\
\hline 150 & 18,05 & 18,10 & 17,95 & 18,00 \\
\hline 180 & 18,10 & 17,95 & 18,05 & 18,00 \\
\hline MÉDIAS & $18,09^{A}$ & $18,06^{A}$ & $18,02^{A}$ & $18,08^{A}$ \\
\hline F (tratamento) & $0,44^{\text {ns }}$ & & & \\
\hline$F$ (tempo) & $1,45^{\mathrm{ns}}$ & & & \\
\hline F (trat*tempo) & $0.68^{\text {ns }}$ & & & \\
\hline
\end{tabular}

$\mathrm{nS}=$ nåo significativo

médias com a mesma letra, no sentido horizontal, não diferem entre si, ao nivel de $5 \%$. 
Tabela 13 - Teores de sólidos solúveis ( ${ }^{\circ}$ Brix) dos néctares dietéticos de goiaba, da variedade Paluma, durante o período de armazenamento.

\begin{tabular}{|c|c|c|c|c|}
\hline \multirow[b]{2}{*}{ Tempo (dias) } & \multicolumn{4}{|c|}{ TRATAMENTOS } \\
\hline & T1 & $\mathrm{T} 2$ & T3 & T4 \\
\hline 0 & 18,00 & 18,00 & 18,00 & 18,00 \\
\hline 30 & 17,90 & 17,85 & 18,05 & 18,10 \\
\hline 60 & 17,95 & 17,95 & 18,00 & 17,95 \\
\hline 90 & 17,95 & 17,95 & 17,90 & 17,90 \\
\hline 120 & 18,00 & 18,00 & 18,10 & 18,05 \\
\hline 150 & 18,00 & 18,05 & 17,95 & 18,00 \\
\hline 180 & 18,00 & 18,00 & 18,00 & 18,00 \\
\hline MÉDIAS & $17,97^{A}$ & $17,97^{A}$ & $18,00^{A}$ & $18,00^{A}$ \\
\hline $\mathrm{F}$ (tratamento) & $0,57^{\text {ns }}$ & & & \\
\hline $\mathrm{F}$ (tempo) & $0,88^{\text {ns }}$ & & & \\
\hline$F$ (trat*tempo) & $0,88^{\text {ns }}$ & & & \\
\hline
\end{tabular}

Tabela 14 - Teores de sólidos solúveis ( $\left.{ }^{\circ} B r i x\right)$ dos néctares dietéticos de goiaba, da variedade Pedro Sato, durante o período de armazenamento.

\begin{tabular}{|c|c|c|c|c|}
\hline \multirow[b]{2}{*}{ Tempo (dias) } & \multicolumn{4}{|c|}{ TRATAMENTOS } \\
\hline & T1 & T2 & T3 & T4 \\
\hline 0 & 18,05 & 17,85 & 18,05 & 18,10 \\
\hline 30 & 17,85 & 18,05 & 17,95 & 17,95 \\
\hline 60 & 18,05 & 17,95 & 17,95 & 18,05 \\
\hline 90 & 17,95 & 17,95 & 17,95 & 17,90 \\
\hline 120 & 18,15 & 18,05 & 18,20 & 18,00 \\
\hline 150 & 18,10 & 18,15 & 17,90 & 18,10 \\
\hline 180 & 17,90 & 18,00 & 17,95 & 18,00 \\
\hline MÉDIAS & $18,00^{A}$ & $18,00^{A}$ & $17,99^{A}$ & $18,01^{A}$ \\
\hline $\mathrm{F}$ (tratamento) & $0,09^{\text {ns }}$ & & & \\
\hline $\mathrm{F}$ (tempo) & $2,12^{\text {ns }}$ & & & \\
\hline$F$ (trat*tempo) & $1,10^{\text {ns }}$ & & & \\
\hline
\end{tabular}

ns= năo significativo

médias com a mesma letra, no sentido horizontal, não diferem entre si, ao nivel de $5 \%$.

Nas Tabelas 15, 16, 17 e 18 observa-se que nos produtos de ambas variedades, tanto os comuns como os dietéticos, a avaliação do parâmetro pH, 
apresentou variação que não diferiu estatísticamente, ao nível de $5 \%$ de significância nos tratamentos, nos tempos de armazenamento e na interação entre tratamento e tempo. Quanto à acidez titulável, houve alterações significativas ao nível de $1 \%$. De acordo com Chitarra \& Chitarra (1990), algumas substâncias permitem variações na acidez titulável, sem variações no $\mathrm{pH}$, por causa do poder tampão delas. $\mathrm{A}$ acidez é usualmente calculada com base no principal ácido presente, expressando-se o resultado com percentagem de acidez titulável, o valor da total, já que há componentes ácidos voláteis que não são detectáveis.

Tabela 15 - Valores de $\mathrm{pH}$ dos néctares comuns de goiaba, da variedade Paluma, durante o periodo de armazenamento.

\begin{tabular}{|c|c|c|c|c|}
\hline \multirow[b]{2}{*}{ Tempo (dias) } & \multicolumn{4}{|c|}{ TRATAMENTOS } \\
\hline & T1 & T2 & T3 & T4 \\
\hline 0 & 3,61 & 3,60 & 3,61 & 3,61 \\
\hline 30 & 3,61 & 3,61 & 3,62 & 3,60 \\
\hline 60 & 3,62 & 3,60 & 3,60 & 3,61 \\
\hline 90 & 3,62 & 3,62 & 3,60 & 3,62 \\
\hline 120 & 3,61 & 3,62 & 3,62 & 3,62 \\
\hline 150 & 3,62 & 3,60 & 3,60 & 3,62 \\
\hline 180 & 3,60 & 3,60 & 3,60 & 3,61 \\
\hline MÉDIAS & $3,61^{A}$ & $3,60^{A}$ & $3,61^{A}$ & $3,61^{A}$ \\
\hline $\mathrm{F}$ (tratamento) & $2,07^{\text {ns }}$ & & & \\
\hline$F($ tempo) & $2,04^{\mathrm{ns}}$ & & & \\
\hline F (trat*tempo) & $1,55^{\text {ns }}$ & & & \\
\hline
\end{tabular}

Berniz (1984), em seu trabalho com néctar de manga, observou a estabilidade de $\mathrm{pH}$ e alterações na acidez. Novaes (1997), pesquisando néctar de morango, observou também estabilidade no $\mathrm{pH}$ e diminuição da acidez. Isto vem enfatizar que variações de acidez nem sempre são acompanhadas por variações de $\mathrm{pH}$. 
abela 16 - Valores de $\mathrm{pH}$ dos néctares comuns de goiaba, da variedade Pedro Sato, durante o periodo de armazenamento.

\begin{tabular}{|c|c|c|c|c|}
\hline \multirow[b]{2}{*}{ Tempo (dias) } & \multicolumn{4}{|c|}{ TRATAMENTOS } \\
\hline & T1 & T2 & T3 & T4 \\
\hline 0 & 3,61 & 3,60 & 3,60 & 3,60 \\
\hline 30 & 3,60 & 3,61 & 3,60 & 3,61 \\
\hline 60 & 3,61 & 3,61 & 3,61 & 3,60 \\
\hline 90 & 3,59 & 3,61 & 3,61 & 3,60 \\
\hline 120 & 3,61 & 3,61 & 3,61 & 3,60 \\
\hline 150 & 3,60 & 3,59 & 3,60 & 3,61 \\
\hline 180 & 3,61 & 3,60 & 3,60 & 3,60 \\
\hline MÉDIAS & $3,61^{A}$ & $3,61^{A}$ & $3,60^{A}$ & $3,60^{A}$ \\
\hline F (tratamento) & $0,29^{\text {ns }}$ & & & \\
\hline$F$ (tempo) & $0,33^{\text {ns }}$ & & & \\
\hline F (trat*tempo) & $1,2^{\text {ns }}$ & & & \\
\hline
\end{tabular}

ns= não significativo

médias com a mesma letra, no sentido horizontal, năo diferem entre si, ao nível de $5 \%$.

Tabela 17 - Valores de $\mathrm{pH}$ dos néctares dietéticos de goiaba, da variedade Paluma, durante o período de armazenamento.

\begin{tabular}{|c|c|c|c|c|}
\hline \multirow[b]{2}{*}{ Tempo (dias) } & \multicolumn{4}{|c|}{ TRATAMENTOS } \\
\hline & T1 & $\mathrm{T} 2$ & T3 & T4 \\
\hline 0 & 3,59 & 3,59 & 3,60 & 3,60 \\
\hline 30 & 3,60 & 3,59 & 3,60 & 3,59 \\
\hline 60 & 3,61 & 3,60 & 3,59 & 3,59 \\
\hline 90 & 3,60 & 3,59 & 3,59 & 3,60 \\
\hline 120 & 3,60 & 3,60 & 3,60 & 3,60 \\
\hline 150 & 3,60 & 3,60 & 3,59 & 3,60 \\
\hline 180 & 3,60 & 3,60 & 3,60 & 3,60 \\
\hline MÉDIAS & $3,60^{A}$ & $3,59^{A}$ & $3,59^{A}$ & $3,60^{A}$ \\
\hline $\mathrm{F}$ (tratamento) & $1,66^{\text {ns }}$ & & & \\
\hline$F$ (tempo) & $0,84^{\mathrm{ns}}$ & & & \\
\hline$F$ (trat*tempo) & $1,37^{\text {ns }}$ & & & \\
\hline
\end{tabular}

ns= năo significativo

médias com a mesma letra, no sentido horizontal, não diferem entre si, ao nivel de $5 \%$. 
Tabela 18 - Valores de $\mathrm{pH}$ dos néctares dietéticos de goiaba, da variedade Pedro Sato, durante o periodo de armazenamento.

\begin{tabular}{|c|c|c|c|c|}
\hline \multirow[b]{2}{*}{ Tempo (dias) } & \multicolumn{4}{|c|}{ TRATAMENTOS } \\
\hline & T1 & T2 & T3 & m4 \\
\hline 0 & 3,60 & 3,60 & $3 ; 60$ & 3,60 \\
\hline 30 & 3,60 & 3,61 & 3,61 & 3,61 \\
\hline 60 & 3,60 & 3,61 & 3,61 & 3,60 \\
\hline 90 & 3,61 & 3,61 & 3,60 & 3,60 \\
\hline 120 & 3,61 & 3,59 & 3,61 & 3,60 \\
\hline 150 & 3,61 & 3,60 & 3,61 & 3,61 \\
\hline 180 & 3,61 & 3,60 & 3,60 & 3,61 \\
\hline MÉDIAS & $3,60^{A}$ & $3,60^{A}$ & $3,60^{A}$ & $3,60^{A}$ \\
\hline F (tratamento) & $0,34^{\mathrm{ns}}$ & & & \\
\hline F (tempo) & $0,66^{\mathrm{ns}}$ & & & \\
\hline$F$ (trat*tempo) & $1,08^{\text {ns }}$ & & & \\
\hline
\end{tabular}

Nas Tabelas 19, 20, 21 e 22 estão as determinações do vácuo, para os produtos em estudo. Observa-se que as alterações em função do tratamento, do tempo e da interação entre tratamento e tempo não diferiram estatisticamente com nivel de $5 \%$ de significância. Os valores encontrados estão de acordo com Jackix (1988); o vácuo recomendado para produtos enlatados é acima de 10pol Hg

O vacuômetro mede a diferença entre a pressão atmosférica e a pressão de dentro do recipiente. O vácuo obtido pelo método térmico, no qual a temperatura de enchimento e o volume do espaço livre estão diretamente relacionados. Quanto maior a temperatura de enchimento, maior será o vácuo; por outro lado, menor será o vácuo quanto maior o espaço livre. Portanto, as medidas obtidas neste trabalho nos indicam que o enchimento da lata foi uniforme, restando o mínimo de espaço livre e que a temperatura de enchimento não variou.

A determinação do vácuo, por meio de vacuômetro, é uma das principais determinações físicas para se verificar a estabilidade do produto. Sabe-se que quanto maior o teor de oxigênio encontrado no produto, menor será o vácuo, estando o produto susceptivel a reações de oxidação, dentre elas a degradação de vitamina C e alterações organolépticas. Pode ainda propiciar o desenvolvimento de microrganismos aeróbios. 
Tabela 19 - Valores de vácuo (pol Hg) dos néctares comuns de goiaba, da variedade Paluma, durante o período de armazenamento.

\begin{tabular}{|c|c|c|c|c|}
\hline \multirow[b]{2}{*}{ Tempo (dias) } & \multicolumn{4}{|c|}{ TRATAMENTOS } \\
\hline & T1 & T2 & T3 & 74 \\
\hline 0 & 11,5 & 11,5 & 11,8 & 71,8 \\
\hline 30 & 12,3 & 10,6 & 12,0 & 11,5 \\
\hline 60 & 12,5 & 12,0 & 11,8 & 12,5 \\
\hline 90 & 10,8 & 12,0 & 11,3 & 12,0 \\
\hline 120 & 11,7 & 10,9 & 10,3 & 10,8 \\
\hline 150 & 12,3 & 12,3 & 12,0 & 11,5 \\
\hline 180 & 11,8 & 11,5 & 11,5 & 11,5 \\
\hline MÉDIAS & $11,8^{\mathrm{A}}$ & $11,5^{\mathrm{A}}$ & $11,5^{\mathrm{A}}$ & $11,6^{A}$ \\
\hline $\mathrm{F}$ (tratamento) & $0,23^{\text {ns }}$ & & & \\
\hline$F($ tempo) & $1,23^{\text {ns }}$ & & & \\
\hline$F$ (trat*tempo) & $0,44^{\mathrm{ns}}$ & & & \\
\hline
\end{tabular}

ns= não significativo

médias com a mesma letra, no sentido horizontal, năo diferem entre si, ao nível de $5 \%$.

Tabela 20 - Valores de vácuo $(\mathrm{pol} \mathrm{Hg}$ ) dos néctares comuns de goiaba, da variedade Pedro Sato, durante o periodo de armazenamento.

\begin{tabular}{ccccc}
\hline & \multicolumn{4}{c}{ TRATAMENTOS } \\
\cline { 2 - 5 } Tempo (dias) & T1 & T2 & T3 & T4 \\
\cline { 2 - 5 } 30 & $11,5^{2}$ & 11,5 & 11,8 & 12,5 \\
60 & 11,8 & 11,1 & 11,5 & 11,8 \\
90 & 12,5 & 11,0 & 11,5 & 11,3 \\
120 & 12,0 & 11,5 & 11,5 & 12,0 \\
150 & 11,5 & 11,9 & 10,9 & 10,8 \\
180 & 10,3 & 12,3 & 11,0 & 12,3 \\
MÉDIAS & 12,3 & 11,5 & 11,5 & 11,5 \\
$F$ (tratamento) & $11,7^{\mathrm{A}}$ & $11,5^{\mathrm{A}}$ & $11,4^{\mathrm{A}}$ & $11,7^{\mathrm{A}}$ \\
$\mathrm{F}$ (tempo) & $0,76^{\text {ns }}$ & & & \\
F (trat*tempo) & $0,68^{\text {ns }}$ & & & \\
\hline ns= não significativo & $1,60^{\text {ns }}$ & & & \\
médias com a mesma letra, no sentido horizontal, não diferem entre si, ao nivel de $5 \%$.
\end{tabular}


Tabela 21 - Valores de vácuo (pol $\mathrm{Hg}$ ) dos néctares dietéticos de goiaba, da variedade Paluma, durante o período de armazenamento.

\begin{tabular}{|c|c|c|c|c|}
\hline \multirow[b]{2}{*}{ Tempo (dias) } & \multicolumn{4}{|c|}{ TRATAMENTOS } \\
\hline & T1 & T2 & T3 & 74 \\
\hline 0 & 11,0 & 10,9 & 17,7 & 91,2 \\
\hline 30 & 10,75 & 12,5 & 11,4 & 11,2 \\
\hline 60 & 11,0 & 11,2 & 11,1 & 11,0 \\
\hline 90 & 11,4 & 11,2 & 11,4 & 11,5 \\
\hline 120 & 11,1 & 11,0 & 11,5 & 12,2 \\
\hline 150 & 12,0 & 11,5 & 11,0 & 11,5 \\
\hline 180 & 10,6 & 11,1 & 10,7 & 10,7 \\
\hline MÉDIAS & $11,1^{\mathrm{A}}$ & $11,3^{A}$ & $11,3^{A}$ & $11,4^{\mathrm{A}}$ \\
\hline$F$ (tratamento) & $0,23^{\text {ns }}$ & & & \\
\hline$F($ tempo) & $0,86^{\text {ns }}$ & & & \\
\hline$F$ (trat*tempo) & $0,59^{\text {ns }}$ & & & \\
\hline
\end{tabular}

Tabela 22 - Valores de vácuo (pol $\mathrm{Hg}$ ) dos néctares dietéticos de goiaba, da variedade Pedro Sato, durante o período de armazenamento.

\begin{tabular}{ccccc}
\hline & \multicolumn{4}{c}{ TRATAMENTOS } \\
\cline { 2 - 5 } Tempo (dias) & T1 & T2 & T3 & T4 \\
\hline 0 & 11,3 & 11,3 & 12,2 & 11,1 \\
30 & 11,2 & 12,0 & 11,3 & 11,7 \\
60 & 11,5 & 11,5 & 12,2 & 10,5 \\
90 & 11,1 & 11,6 & 11,7 & 11,2 \\
120 & 10,5 & 10,9 & 11,5 & 12,3 \\
150 & 11,7 & 10,9 & 11,5 & 12,0 \\
180 & 11,5 & 11,25 & 11,2 & 11,9 \\
MÉDIAS & $11,3^{\mathrm{A}}$ & $11,4^{\mathrm{A}}$ & $11,7^{\mathrm{A}}$ & $11,6^{\mathrm{A}}$ \\
F (tratamento) & $0,75^{\mathrm{As}}$ & & & \\
F (tempo) & $0,09^{\mathrm{ns}}$ & & & \\
F (trat"tempo) & $0,95^{\mathrm{ns}}$ & & & \\
\hline
\end{tabular}

ns= nåo significativo

médias com a mesma letra, no sentido horizontal, nåo diferem entre si, ao nivel de $5 \%$. 
De acordo com Uboldi Eiroa (1989), o oxigênio dissolvido em sucos é removido por aquecimento, na pasteurização. Por isso, o processo de enchimento a quente e a recravação devem ser efetuados rapidamente, a fim de se evitar oscilações na temperatura, vácuos menores que o recomendado e a diminuição da vida útil do produto. Richards (1996), processando morango em calda, obteve variações nas medidas de vácuo dos produtos enlatados.

As determinações de peso bruto dos néctares estão nas Tabelas 23, 24, 25 e 26, pelas quais pode -se observar que as diferenças não foram significativas ao nível de $5 \%$. Portanto, os tratamentos, o tempo e a interação entre tratamento e tempo não diferiram estatisticamente.

Tabela 23 - Valores dos pesos brutos ( $\mathrm{g}$ ) das latas dos néctares comuns de goiaba, da variedade Paluma, durante o periodo de armazenamento.

\begin{tabular}{|c|c|c|c|c|}
\hline \multirow[b]{2}{*}{ Tempo (dias) } & \multicolumn{4}{|c|}{ TRATAMENTOS } \\
\hline & T1 & T2 & T3 & T4 \\
\hline 0 & 406,40 & 408,65 & 405,84 & 411,24 \\
\hline 30 & 406,09 & 407,64 & 407,99 & 408,78 \\
\hline 60 & 405,76 & 408,90 & 408,96 & 406,55 \\
\hline 90 & 410,46 & 412,29 & 407,24 & 409,43 \\
\hline 120 & 409,10 & 409,98 & 410,97 & 409,06 \\
\hline 150 & 407,78 & 405,78 & 407,40 & 408,35 \\
\hline 180 & 405,87 & 406,77 & 407,27 & 408,5 \\
\hline MEEDIAS & $407,35^{A}$ & $408,57^{A}$ & $407,95^{A}$ & $408,84^{A}$ \\
\hline$F$ (tratamento) & $0,91^{\mathrm{ns}}$ & & & \\
\hline$F$ (tempo) & $1,57^{\text {ns }}$ & & & \\
\hline$F$ (trat”tempo) & $0,71^{\text {ns }}$ & & & \\
\hline
\end{tabular}

nS= năo significativo

médias com a mesma letra, no sentido horizontal, não diferem entre si, ao nível de $5 \%$.

Assim, pode-se dizer que as latas foram preenchidas com quantidade uniforme de néctar. O peso bruto é importante para o transporte e armazenamento. Ao consumidor interessa apenas o peso líquido do produto, por isso o peso bruto não aparece no rótulo das embalagens. 
Tabela 24 - Valores dos pesos brutos ( $\mathrm{g}$ ) das latas dos néctares comuns de goiaba, da variedade Pedro Sato, durante o periodo de armazenamento.

\begin{tabular}{|c|c|c|c|c|}
\hline \multirow[b]{2}{*}{ Tempo (dias) } & \multicolumn{4}{|c|}{ TRATAMENTOS } \\
\hline & T1 & T2 & T3 & T4 \\
\hline 0 & 405,75 & 405,77 & 408,60 & 405,84 \\
\hline 30 & 408,47 & 407,42 & 407,38 & 408,94 \\
\hline 60 & 407,47 & 407,59 & 408,88 & 406,85 \\
\hline 90 & 409,19 & 408,79 & 411,01 & 410,68 \\
\hline 120 & 405,52 & 406,71 & 409,40 & 407,09 \\
\hline 150 & 407,01 & 407,98 & 408,39 & 407,21 \\
\hline 180 & 409,00 & 406,73 & 405,08 & 406,42 \\
\hline MÉDIAS & $407,48^{A}$ & $407,28^{A}$ & $408,39^{A}$ & $407,57^{A}$ \\
\hline$F$ (tratamento) & $0,41^{\mathrm{ns}}$ & & & \\
\hline$F$ (tempo) & $1,25^{\text {ns }}$ & & & \\
\hline F (trat"tempo) & $0,35^{\mathrm{ns}}$ & & & \\
\hline
\end{tabular}

ns= não significativo

médias com a mesma letra, no sentido horizontal, năo diferem entre si, ao nivel de $5 \%$.

Tabela 25 - Valores dos pesos brutos ( $\mathrm{g}$ ) das latas dos néctares dietéticos de goiaba, da variedade Paluma, durante o período de armazenamento.

\begin{tabular}{ccccc} 
Tempo (dias) & T1 & T2 & T3 & T2 \\
0 & 408,99 & 408,39 & 405,80 & 40 \\
30 & 408,96 & 409,55 & 405,32 & 405,34 \\
60 & 408,29 & 408,88 & 407,22 & 407,14 \\
90 & 408,92 & 408,45 & 407,27 & 408,91 \\
120 & 408,90 & 408,90 & 409,13 & 407,60 \\
150 & 408,22 & 408,68 & 406,13 & 405,40 \\
180 & 411,31 & 409,73 & 407,85 & 407,60 \\
MÉDIAS & $409,10^{\mathrm{A}}$ & $408,94^{\mathrm{A}}$ & $406,96^{\mathrm{A}}$ & $406,93^{\mathrm{A}}$ \\
F (tratamento) & $2,51^{\text {ns }}$ & & & \\
F (tempo) & $0,57^{\text {ns }}$ & & & \\
F (trat”tempo) & $0,20^{\text {ns }}$ & & & \\
\hline
\end{tabular}

ns= não significativo

médias com a mesma letra, no sentido horizontal, nåo diferem entre si, ao nivel de $5 \%$. 
Tabela 26 - Valores dos pesos brutos ( $\mathrm{g}$ ) das latas dos néctares dietéticos de goiaba, da variedade Pedro Sato, durante o período de armazenamento.

\begin{tabular}{|c|c|c|c|c|}
\hline \multirow[b]{2}{*}{ Tempo (dias) } & \multicolumn{4}{|c|}{ TRATAMENTOS } \\
\hline & $\mathrm{T} 1$ & T2 & T3 & T4 \\
\hline 0 & 405,75 & 407,24 & 407,13 & 405,89 \\
\hline 30 & 407,69 & 407,69 & 408,75 & 408,51 \\
\hline 60 & 407,05 & 409,95 & 406,61 & 405,45 \\
\hline 90 & 408,72 & 408,59 & 410,74 & 406,74 \\
\hline 120 & 407,64 & 405,86 & 405,84 & 406,04 \\
\hline 150 & 406,46 & 409,11 & 405,52 & 405,72 \\
\hline 180 & 407,24 & 406,82 & 409,57 & 411,52 \\
\hline MÉDIAS & $407,22^{A}$ & $407,89^{A}$ & $407,74^{A}$ & $407,12^{A}$ \\
\hline F (tratamento) & $0,41^{\mathrm{ns}}$ & & & \\
\hline$F($ tempo) & $1,78^{\text {ns }}$ & & & \\
\hline F (trat*tempo) & $0,99^{\text {ns }}$ & & & \\
\hline
\end{tabular}

ns= não significativo

médias com a mesma letra, no sentido horizontal, não diferem entre si, ao nível de $5 \%$.

Como os pesos brutos, os pesos líquidos apresentados nas Tabelas $27,28,29$ e 30, também não apresentaram diferenças estatísticas significativas entre tratamentos, no tempo e na interação entre tratamento e tempo.

Tabela 27 - Valores dos pesos líquidos ( $\mathrm{g}$ ) das latas dos néctares comuns de goiaba, da variedade Paluma, durante o periodo de armazenamento.

\begin{tabular}{ccccc} 
Tempo (dias) & \multicolumn{5}{c}{ TRATAMENTOS } \\
\hline 0 & T1 & T2 & T3 & T4 \\
\hline 30 & 356,44 & 358,84 & 355,69 & 360,67 \\
60 & 355,02 & 356,47 & 357,09 & 355,49 \\
90 & 355,98 & 353,31 & 358,47 & 355,88 \\
120 & 359,45 & 361,25 & 355,87 & 358,79 \\
150 & 358,39 & 359,23 & 361,31 & 358,15 \\
180 & 357,16 & 354,41 & 356,58 & 355,79 \\
MÉdDIAS & 356,60 & 357,05 & 356,49 & 357,79 \\
F (tratamento) & $357,01^{\mathrm{A}}$ & $357,22^{\mathrm{A}}$ & $357,36^{\mathrm{A}}$ & $357,51^{\mathrm{A}}$ \\
F (tempo) & $0,08^{\text {ns }}$ & & & \\
F (trat*tempo) & $1,94^{\text {ns }}$ & & & \\
\hline
\end{tabular}

ns= năo significativo

médias com a mesma letra, no sentido horizontal, nåo diferem entre si, ao nível de $5 \%$. 
Tabela 28 - Valores dos pesos líquidos (g) das latas dos néctares comuns de goiaba, da variedade Pedro Sato, durante o periodo de armazenamento.

\begin{tabular}{ccccc}
\hline \multicolumn{5}{c}{ TRATAMENTOS } \\
Tempo (dias) & \multicolumn{5}{c}{ T1 } & T2 & T3 & T4 \\
\hline 0 & 354,82 & 355,64 & 358,44 & 357,15 \\
30 & 356,77 & 354,26 & 354,05 & 357,45 \\
60 & 356,59 & 356,50 & 358,91 & 356,10 \\
90 & 358,88 & 356,86 & 360,86 & 359,90 \\
120 & 354,54 & 355,86 & 355,47 & 357,56 \\
150 & 355,61 & 355,50 & 357,84 & 356,46 \\
180 & 358,15 & 357,55 & 354,96 & 354,91 \\
MÉDIAS & $356,48^{\mathrm{A}}$ & $356,02^{\mathrm{A}}$ & $357,22^{\mathrm{A}}$ & $357,07^{\mathrm{A}}$ \\
F (tratamento) & $0,53^{\mathrm{ns}}$ & & & \\
F (tempo) & $1,33^{\text {ns }}$ & & & \\
F (trattempo) & $0,56^{\text {ns }}$ & & & \\
\hline
\end{tabular}

ns= nåo significativo

médias com a mesma letra, no sentido horizontal, não diferem entre si, ao nivel de $5 \%$.

Tabela 29 - Valores dos pesos líquidos (g) das latas dos néctares dietéticos de goiaba, da variedade Paluma, durante o período de armazenamento.

\begin{tabular}{|c|c|c|c|c|}
\hline \multirow[b]{2}{*}{ Tempo (dias) } & \multicolumn{4}{|c|}{ TRATAMENTOS } \\
\hline & T1 & T2 & T3 & T4 \\
\hline 0 & 357,72 & 351,81 & 355,31 & 355,33 \\
\hline 30 & 355,24 & 356,94 & 352,19 & 354,04 \\
\hline 60 & 357,97 & 358,22 & 356,50 & 353,89 \\
\hline 90 & 352,90 & 354,12 & 356,49 & 358,21 \\
\hline 120 & 352,31 & 352,31 & 358,16 & 355,72 \\
\hline 150 & 354,20 & 357,83 & 352,69 & 354,50 \\
\hline 180 & 355,62 & 355,74 & 354,68 & 304,96 \\
\hline MÉDIAS & $355,14^{\mathrm{A}}$ & $355,28^{A}$ & $355,14^{\mathrm{A}}$ & $348,10^{A}$ \\
\hline F (tratamento) & $1,03^{\mathrm{ns}}$ & & & \\
\hline F (tempo) & $1,05^{\text {ns }}$ & & & \\
\hline F (trat*tempo) & $1,12^{\text {ns }}$ & & & \\
\hline
\end{tabular}

ns= nåo significativo

médias com a mesma letra, no sentido horizontal, não diferem entre si, ao nivel de $5 \%$. 
Tabela 30 - Valores dos pesos líquidos ( $\mathrm{g}$ ) das latasdos néctares dietéticos de goiaba, da variedade Pedro Sato, durante o período de armazenamento.

\begin{tabular}{|c|c|c|c|c|}
\hline \multirow[b]{2}{*}{ Tempo (dias) } & \multicolumn{4}{|c|}{ TRATAMENTOS } \\
\hline & T1 & T2 & T3 & T4 \\
\hline 0 & 355,07 & 356,36 & 356,37 & 355,27 \\
\hline 30 & 357,32 & 356,72 & 357,71 & 357,60 \\
\hline 60 & 355,89 & 358,72 & 354,14 & 354,28 \\
\hline 90 & 358,03 & 358,07 & 360,16 & 355,78 \\
\hline 120 & 356,41 & 355,60 & 355,15 & 357,28 \\
\hline 150 & 355,75 & 357,50 & 357,54 & 354,20 \\
\hline 180 & 356,18 & 355,79 & 358,60 & 360,94 \\
\hline MÉDIAS & $356,38^{A}$ & $356,97^{A}$ & $357,11^{A}$ & $356,48^{A}$ \\
\hline $\mathrm{F}$ (tratamento) & $0,28^{n s}$ & & & \\
\hline$F$ (tempo) & $1,21^{\mathrm{ns}}$ & & & \\
\hline$F($ trat*tempo) & $0,87^{\text {ns }}$ & & & \\
\hline
\end{tabular}

ns= náo significativo

médias com a mesma letra, no sentido horizontal, nåo diferem entre si, ao nivel de $5 \%$.

Estas análises confirmam mais uma vez que a quantidade de néctar na lata foi constante, sendo um fato muito importante, já que o peso líquido mínimo dos produtos vem no rótulo apresentando portanto os néctares, boa qualidade do ponto de vista físico.

\subsection{Análises sensoriais dos néctares comuns e dietéticos.}

Em relação aos néctares comuns de ambas variedades, Paluma e Pedro Sato, - tratamento 1 obteve maiores médias quanto ao atributo sabor diferindo estatisticamente dos outros tratamentos (Tabelas 31 e 32); entretanto, as médias de todos os tratamentos foram muito semelhantes e correspondiam à sensação "bom" (78), na escala numérica estruturada de nove pontos.

Quanto ao sabor dos néctares dietéticos (Tabelas 33 e 34), notou-se maiores médias no tratamento 1 , diferindo estatisticamente dos outros tratamentos. O sabor do néctar deste tratamento (T1) teve pouca variação durante o armazenamento. Este fato pode ser atribuído ao armazenamento refrigerado, uma vez que baixas temperaturas contribuem para a manutenção organoléptica dos produtos. 
Tabela 31 - Valores atribuídos ao sabor dos néctares comuns de goiaba, da variedade Paluma, durante o armazenamento.

\begin{tabular}{|c|c|c|c|c|}
\hline \multirow[b]{2}{*}{ Tempo (dias) } & \multicolumn{4}{|c|}{ TRATAMENTOS } \\
\hline & T1 & T2 & T3 & $\mathrm{T} 4$ \\
\hline 30 & 8,31 & 8,06 & 7,56 & 7,31 \\
\hline 60 & 8,19 & 7,50 & 7,12 & 6,94 \\
\hline 90 & 8,00 & 7,00 & 6,81 & 6,90 \\
\hline MÉDIAS & $8,16^{A}$ & $7,52^{8}$ & $7,16^{c}$ & $7,04^{c}$ \\
\hline F (tratamento) & $60,25^{\star *}$ & & & \\
\hline F (tempo) & $32,71^{\text {** }}$ & & & \\
\hline F (trat*tempo) & $2,39^{\star}$ & & & \\
\hline
\end{tabular}

ns= nåo significativo

**=significativo ao nivel de $1 \%$

*=significativo ao nivel de $5 \%$.

médias com a mesma letra, no sentido horizontal, năo diferem entre sí, ao nivel de $5 \%$.

Tabela 32 - Valores atribuídos ao sabor dos néctares comuns de goiaba, da variedade Pedro Sato, durante o armazenamento.

\begin{tabular}{lcccc}
\hline & \multicolumn{4}{c}{ TRATAMENTOS } \\
Tempo (dias) & T1 & T2 & T3 & T4 \\
\hline 30 & 8,31 & 8,06 & 7,56 & 7,37 \\
60 & 8,25 & 7,44 & 7,25 & 7,19 \\
90 & 8,12 & 7,00 & 7,12 & 6,87 \\
MÉDIAS & $8,22^{\mathrm{A}}$ & $7,50^{\mathrm{B}}$ & $7,31^{\mathrm{C}}$ & $7,14^{\mathrm{C}}$ \\
F (tratamento) & $53,69^{\star \star}$ & & & \\
F (tempo) & $23,55^{\star \star}$ & & & \\
F (trat*tempo) & $2,86^{\star}$ & & & \\
\hline
\end{tabular}

ns= não significativo

**=significativo ao nivel de $1 \%$

*=significativo ao nivel de $5 \%$.

médias com a mesma letra, no sentido horizontal, năo diferem entre si, ao nivel de $5 \%$

Os néctares comuns e dietéticos, do tratamento 2 , das duas variedades, foram os que apresentaram, relativamente, as maiores reduções nas médias finais durante o armazenamento. Este fato pode ter ocorrido devido ao armazenamento do produto à temperatura ambiente. 
Tabela 33 - Valores atribuidos ao sabor dos néctares dietéticos de goiaba, da variedade Paluma, durante o armazenamento.

\begin{tabular}{|c|c|c|c|c|}
\hline \multirow[b]{2}{*}{ Tempo (dias) } & \multicolumn{4}{|c|}{ TRATAMENTOS } \\
\hline & $\mathrm{T1}$ & $\mathrm{T} 2$ & T3 & T4 \\
\hline 30 & 7,37 & 7,37 & 6,62 & 6,12 \\
\hline 60 & 7,25 & 6,62 & 6,06 & 5,44 \\
\hline 90 & 7,00 & 6,00 & 5,62 & 4,87 \\
\hline MÉDIAS & $7,28^{A}$ & $6,66^{\mathrm{B}}$ & $6,10^{C}$ & $5,47^{C}$ \\
\hline $\mathrm{F}$ (tratamento) & $165,20^{\star \star}$ & & & \\
\hline F (tempo) & $99,95^{\star \star}$ & & & \\
\hline F (trat*tempo) & $5,07^{\star \star}$ & & & \\
\hline
\end{tabular}

Tabela 34 - Valores atribuídos ao sabor dos néctares dietéticos de goiaba, da variedade Pedro Sato, durante o armazenamento.

\begin{tabular}{|c|c|c|c|c|}
\hline \multirow[b]{2}{*}{ Tempo (dias) } & \multicolumn{4}{|c|}{ TRATAMENTOS } \\
\hline & T1 & T2 & T3 & $\mathrm{T} 4$ \\
\hline 30 & 7,12 & 7,06 & 6,25 & 5,62 \\
\hline 60 & 7,12 & 6,19 & 5,56 & 5,00 \\
\hline 90 & 7,00 & 5,62 & 5,31 & 5,00 \\
\hline MÉDIAS & $7,08^{A}$ & $6,29^{B}$ & $5,70^{C}$ & $5,20^{D}$ \\
\hline F (tratamento) & $125,17^{\star \star}$ & & & \\
\hline F (tempo) & $41,29^{\star \star}$ & & & \\
\hline F (trat*tempo) & $5,41^{\star \star}$ & & & \\
\hline
\end{tabular}

Pode-se observar que o tratamento 4 das duas variedades, obteve as menores médias, que foram decrescendo durante o período de armazenamento e atingiram médias inferiores ao valor sete, após 90 dias. Os dietéticos chegaram a apresentar valores inferiores a 5 e neste caso, as médias correspondem a sensação "regular" na escala utilizada. A obtenção de menores médias nos tratamentos 3 e 4 pode ter ocorrido por causa da acidez, pois estes tratamentos receberam a adição de sorbato de potássio e ácido ascórbico. Nota-se, assim que a preferência dos degustadores é 
por produtos pouco ácidos. No estudo de néctar dietético de morango, Novaes (1997) também detectou que as menores médias em relação ao sabor, foram as dos tratamentos que continham ácido ascórbico. Com o armazenamento, as médias dos sabores tenderam a diminuir, sem que houvesse a descaracterização do produto.

Nas Tabelas 35, 36, 37 e 38, observa-se os valores de consistência dos néctares, onde nota-se redução nesse atributo de qualidade, para os néctares das duas variedades e que o tratamento 2 apresentou, com o tempo, a maior redução nesse atributo. Nos demais tratamentos, a consistência manteve-se constante durante o armazenamento. As médias das avaliações correspondem à sensação "bom" na escala numérica estruturada e as médias do tratamento 1 diferiu estatisticamente dos demais tratamentos.

Tabela 35 - Valores atribuídos à consistência dos néctares comuns de goiaba, da variedade Paluma, durante o armazenamento.

\begin{tabular}{|c|c|c|c|c|}
\hline \multirow[b]{2}{*}{ Tempo (dias) } & \multicolumn{4}{|c|}{ TRATAMENTOS } \\
\hline & $T 1$ & T2 & T3 & T4 \\
\hline 30 & 8,12 & 8,00 & 7,81 & 8,12 \\
\hline 60 & 8,06 & 7,90 & 7,90 & 7,90 \\
\hline 90 & 8,00 & 7,69 & 7,69 & 7,81 \\
\hline MÉDIAS & $8,06^{A}$ & $7,85^{8}$ & $7,79^{8}$ & $7,93^{\mathrm{AB}}$ \\
\hline F (tratamento) & $2,91^{\star}$ & & & \\
\hline$F($ tempo) & $3,41^{\star}$ & & & \\
\hline F (trat*tempo) & $0,40^{n s}$ & & & \\
\hline
\end{tabular}

Pode-se observar que houve alterações na consistência dos néctares (Tabelas 35, 3637 e 38), durante o período de armazenamento. Entretanto, mesmo com as alterações, as notas continuaram indicando "Bom" (7-8), na escala numérica estruturada.

Os pesquisadores Salomón et al. (1977) detectaram diminuição da consistência de néctares armazenados por 180 dias em temperatura ambiente e concluíram que isto ocorreu em virtude da hidrólise de matéria péctica. 
Tabela 36 - Valores atribuídos à consistência dos néctares comuns de goiaba, da variedade Pedro Sato, durante o armazenamento.

\begin{tabular}{ccccc}
\hline & \multicolumn{4}{c}{ TRATAMENTOS } \\
\cline { 2 - 4 } Tempo (dias) & T1 & T2 & T3 & T4 \\
\hline 30 & 8,31 & 8,12 & 8,06 & 8,19 \\
60 & 8,25 & 7,87 & 7,87 & 8,00 \\
90 & 8,12 & 7,81 & 8,06 & 8,06 \\
MÉDIAS & $8,22^{\mathrm{A}}$ & $7,93^{\mathrm{C}}$ & $8,00^{8 \mathrm{C}}$ & $8,08^{8}$ \\
F (tratamento) & $6,31^{\text {** }}$ & & & \\
F (tempo) & $4,77^{\text {** }}$ & & & \\
F (trattempo) & $0,93^{\text {ns }}$ & & & \\
\end{tabular}

ns= näo significativo

**=significativo ao nivel de $1 \%$.

*=significativo ao nivel de $5 \%$.

médias com a mesma letra, no sentido horizontal, năo diferem entre si, ao nivel de $5 \%$.

Tabela 37 - Valores atribuídos à consistência dos néctares dietéticos de goiaba, da variedade Paluma, durante $\mathrm{o}$ armazenamento.

\begin{tabular}{|c|c|c|c|c|}
\hline \multirow[b]{2}{*}{ Tempo (dias) } & \multicolumn{4}{|c|}{ TRATAMENTOS } \\
\hline & T1 & T2 & T3 & T4 \\
\hline 30 & 8,62 & 8,37 & 8,25 & 8,12 \\
\hline 60 & 8,56 & 8,06 & 8,19 & 8,25 \\
\hline 90 & 8,37 & 7,87 & 8,19 & 8,19 \\
\hline MÉDIAS & $8,52^{A}$ & $8,10^{B}$ & $8,20^{B}$ & $8,18^{B}$ \\
\hline F (tratamento) & $10,15^{\star \star}$ & & & \\
\hline F (tempo) & $3,60^{\star}$ & & & \\
\hline F (trat'tempo) & $1,70^{\text {ns }}$ & & & \\
\hline
\end{tabular}

ns= náo significativo

**=significativo ao nivel de $1 \%$.

*=significativo ao nível de $5 \%$.

médias com a mesma letra, no sentido horizontal, năo diferem entre si, ao nível de $5 \%$. 
Tabela 38 - Valores atribuidos à consistência dos néctares dietéticos de goiaba, da variedade Pedro Sato, durante o armazenamento.

\begin{tabular}{|c|c|c|c|c|}
\hline \multirow[b]{2}{*}{ Tempo (dias) } & \multicolumn{4}{|c|}{ TRATAMENTOS } \\
\hline & T1 & T2 & T3 & T4 \\
\hline 30 & 8,19 & 8,12 & 8,25 & 8,25 \\
\hline 60 & 8,12 & 7,62 & 7,50 & 8,00 \\
\hline 90 & 8,06 & 7,62 & 7,00 & 7,69 \\
\hline MÉDIAS & $8,12^{A}$ & $7,79^{8}$ & $7.58^{8}$ & $7,97^{A}$ \\
\hline F (tratamento) & $11,50^{\star \star}$ & & & \\
\hline F (tempo) & $26,53^{\star \star}$ & & & \\
\hline$F$ (trattempo) & 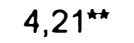 & & & \\
\hline
\end{tabular}

Quanto à análise subjetiva da cor, para os néctares comuns (Tabelas 39 e 40), verificou-se que o tratamento 1, para a variedade Paluma, e os tratamentos 1 e 3, para a variedade Pedro Sato, apresentaram os melhores resultados, ou seja, com menor redução das médias obtidas na avaliação do atributo em questão. Também observouse que o tratamento 4, para a variedade Pedro Sato, apresentou uma diminuição continua deste atributo, durante o periodo de armazenamento.

Tabela 39 - Valores atribuidos à cor dos néctares comuns de goiaba, da variedade Paluma, durante o armazenamento.

\begin{tabular}{|c|c|c|c|c|}
\hline \multirow[b]{2}{*}{ Tempo (dias) } & \multicolumn{4}{|c|}{ TRATAMENTOS } \\
\hline & T1 & T2 & T3 & T4 \\
\hline 30 & 8,64 & 8,58 & 8,40 & 8,04 \\
\hline 60 & 8,45 & 7,95 & 8,07 & 7,52 \\
\hline 90 & 8,33 & 7,76 & 7,94 & 7,52 \\
\hline MÉDIAS & $8,47^{A}$ & $8,10^{8}$ & $8,14^{8}$ & $7,69^{c}$ \\
\hline F (tratamento) & $19,66^{\star \star}$. & & & \\
\hline$F$ (tempo) & $20,31^{\star \star}$ & & & \\
\hline$F$ (trat*tempo) & $0,94^{\text {ns }}$ & & & \\
\hline
\end{tabular}


Em relação aos néctares dietéticos, pode-se notar pelas tabelas 41 e 42 que a cor dos néctares da variedade Paluma permaneceu estável com o armazenamento; 0 tratamento que apresentou maior alteração foi o 4. Os néctares dos tratamentos $2,3 \mathrm{e}$ 4, da Pedro Sato, tiveram notas que diminuíram com o perído de armazenamento. Porém, as médias obtidas nas avaliações, tanto para os néctares comuns como para os dietéticos, correspondem à sensação "bom" (7 e 8), na escala numérica utilizada.

Tabela 40 - Valores atribuídos à cor dos néctares comuns de goiaba, da variedade Pedro Sato, durante o armazenamento.

\begin{tabular}{|c|c|c|c|c|}
\hline \multirow[b]{2}{*}{ Tempo (dias) } & \multicolumn{4}{|c|}{ TRATAMENTOS } \\
\hline & T1 & T2 & T3 & T4 \\
\hline 30 & 8,62 & 8,12 & 8,06 & 8,56 \\
\hline 60 & 8,37 & 7,94 & 8,06 & 7,87 \\
\hline 90 & 8,25 & 7,87 & 8,06 & 7,56 \\
\hline MÉDIAS & $8,41^{A}$ & $7,97^{\mathrm{B}}$ & $8,06^{B}$ & $8,00^{B}$ \\
\hline F (tratamento) & $11,03^{\star \star}$ & & & \\
\hline F (tempo) & $15,23^{\star \star}$ & & & \\
\hline F (trat"tempo) & $4,16^{\star \star}$ & & & \\
\hline
\end{tabular}

Tabela 41 - Valores atribuídos à cor dos néctares dietéticos de goiaba, da variedade Paluma, durante o armazenamento.

\begin{tabular}{|c|c|c|c|c|}
\hline \multirow[b]{2}{*}{ Tempo (dias) } & \multicolumn{4}{|c|}{ TRATAMENTOS } \\
\hline & T1 & T2 & 13 & T4 \\
\hline 30 & 8,75 & 8,69 & 8,56 & 8,81 \\
\hline 60 & 8,75 & 8,31 & 8,37 & 8,00 \\
\hline 90 & 8,37 & 8,00 & 8,12 & 7,69 \\
\hline MÉDIAS & $8,62^{A}$ & $8,33^{B}$ & $8,35^{8}$ & $8,16^{\mathrm{C}}$ \\
\hline F (tratamento) & $10,16^{\star \star}$ & & & \\
\hline F (tempo) & $40,58^{\star \star}$ & & & \\
\hline F (trat"tempo) & $3,76^{\star \star}$ & & & \\
\hline
\end{tabular}

ns= näo significativo

**=significativo ao nivel de $1 \%$

*=significativo ao nível de $5 \%$.

médias com a mesma letra, no sentido horizontal, năo diferem entre si, ao nível de $5 \%$. 
Tabela 42 - Valores atribuidos à cor dos néctares dietéticos de goiaba, da variedade Pedro Sato, durante o armazenamento.

\begin{tabular}{|c|c|c|c|c|}
\hline \multirow[b]{2}{*}{ Tempo (dias) } & \multicolumn{4}{|c|}{ TRATAMENTOS } \\
\hline & T1 & T2 & T3 & T4 \\
\hline 30 & 8,84 & 8,89 & 8,55 & 8,55 \\
\hline 60 & 8,95 & 8,14 & 8,00 & 7,92 \\
\hline 90 & 8,78 & 7,67 & 7,64 & 7,49 \\
\hline MÉDIAS & $8,86^{A}$ & $8,28^{8}$ & $8,08^{\mathrm{BC}}$ & $8,02^{C}$ \\
\hline$F$ (tratamento) & $40,41^{\star \star}$ & & & \\
\hline$F$ (tempo) & $49,71^{\star \star}$ & & & \\
\hline$F($ trat*tempo) & $5,82^{\star \star}$ & & & \\
\hline
\end{tabular}

ns= năo significativo

**=significativo ao nivel de $1 \%$

*=significativo ao nivel de $5 \%$.

médias com a mesma letra, no sentido horizontal, nåo diferem entre si, ao nível de $5 \%$.

A menor alteração na cor dos néctares do tratamento 1, pode ser atribuida ao armazenamento sob refrigeração. Observou-se ainda que o tratamento 1 diferiu estatisticamente dos demais e que apresentou-se com as maiores médias.

Para Graumlich et al. (1986) a descaracterização da cor ocorre devido à oxidação da vitamina $\mathrm{C}$, responsável pelo escurecimento dos sucos que contêm ácido ascórbico.

As alterações de cor e sabor também foram constatadas por Oliva et al. (1996) em néctar de acerola armazenado em temperatura ambiente. Estudando suco de acerola, Rocha (1988) verificou que durante o armazenamento em temperatura ambiente, houve escurecimento e alteração de sabor.

A variável cor, do néctar comum da variedade Paluma e do néctar dietético da variedade Pedro Sato, foi transformada utilizando-se do método potência ótima de Box Cox à 2 e 4,1, respectivamente, do móludo SAS/Insight. 


\section{CONCLUSŐES}

Os néctares comuns e dietéticos de goiaba, das variedades Paluma e Pedro Sato, apresentaram boa qualidade sob o ponto de vista físico-químico e organoléptico.

O tratamento que utilizou o armazenamento refrigerado foi o mais eficiente para a manutenção da qualidade dos néctares comuns e dietéticos das duas variedades, principalmente quanto ao teor de vitamina $\mathrm{C}$ e quanto ao sabor da fruta, sendo considerado o melhor tratamento aplicado. No final de 180 dias os néctares comuns e dietéticos, desse tratamento, apresentavam teores de ácido ascórbico na faixa de $30 \mathrm{mg} 100 \mathrm{~g}^{-1}$ néctar, o que equivale a metade do teor diário recomendado para o organismo humano adulto.

O tratamento com adição de ácido ascórbico, foi considerado eficiente para a revitaminação dos néctares, porém não apresentou-se adequado para a qualidade dos néctares quanto ao sabor e à cor dos produtos.

Os néctares dietéticos, assim como os comuns, tiveram boa aceitação por parte dos degustadores, que consideraram o sorbitol como edulcorante adequado para o processamento de néctar dietético.

Durante o periodo de 90 dias de armazenamento, os néctares mantiveram bons índices de aceitação, apresentando os néctares comuns a avaliações quanto ao sabor variando de 8-7 (bom), e os néctares dietéticos apresentaram atributos variando de 7 (bom)-4(regular).

Pelas avaliações obtidas na análise sensorial e nas análises químicas dos néctares, pode-se concluir que as duas variedades, Paluma e Pedro Sato, são adequadas para o processamento de néctar de goiaba. 
ANEXOS 
ANEXO A 1 Análise de variância dos teores de ácido ascórbico dos néctares comuns de goiaba, das variedade Paluma, durante o período de armazenamento.

\begin{tabular}{|c|c|c|c|c|}
\hline Causa de variação & G.L. & S.Q. & Q.M. & $F$ \\
\hline $\begin{array}{l}\text { Tratamento } \\
\text { Resíduo (a) }\end{array}$ & $\begin{array}{l}3 \\
4\end{array}$ & $\begin{array}{r}4836,1338 \\
7,3080\end{array}$ & $\begin{array}{r}1612,0446 \\
1,8270\end{array}$ & $3406,54^{t \star}$ \\
\hline $\begin{array}{l}\text { Parcelas } \\
\text { Tempo } \\
\text { Tratamentoxtempo } \\
\text { Residuo (b) }\end{array}$ & $\begin{array}{l}7 \\
6 \\
18 \\
24\end{array}$ & $\begin{array}{c}4843,4418 \\
530,2653 \\
68,771 \\
11,3573\end{array}$ & $\begin{array}{r}691,9202 \\
88,3776 \\
3,8210 \\
0,4730\end{array}$ & $\begin{array}{r}186,76^{\star \star} \\
8,07^{\star \star}\end{array}$ \\
\hline Total & 55 & 5453,8415 & & \\
\hline
\end{tabular}

* significativo, ao nivel de $5 \%$ de significância

** significativo, ao nivel de $1 \%$ de significância

ANEXO A 2 Análise de variância dos teores de ácido ascórbico dos néctares comuns de goiaba, das variedade Pedro Sato, durante o período de armazenamento.

\begin{tabular}{llrrrr} 
Causa de variação & G.L. & S.Q. & Q.M. & F \\
\hline Tratamento & 3 & 4990,4990 & 1663,4997 & $3087,90^{\star \star}$ \\
Residuo (a) & 4 & 6,7608 & 1,6902 & \\
\hline Parcelas & 7 & 4997,2602 & 713,8431 & \\
Tempo & 6 & 660,4152 & 110,0692 & $204,32^{\star \star}$ \\
Tratamentoxtempo & 18 & 99,8164 & 5,5454 & $10,29^{\star \star}$ \\
Residuo (b) & 24 & 12,9292 & 0,5387 & \\
Total & 55 & 5770,4206 & &
\end{tabular}

** significativo, ao nivel de $1 \%$ de significância

ANEXO A 3 Análise de variância dos teores de ácido ascórbico dos néctares dietéticos de goiaba, das variedade Paluma, durante o periodo de armazenamento.

\begin{tabular}{llrrr} 
Causa de variação & G.L. & S.Q. & Q.M. & F \\
Tratamento & 3 & 5724,85961 & 1908,28653 & $413,05^{\star \star}$ \\
Residuo (a) & 4 & 18,47952 & 4,61988 & \\
Parcelas & 7 & 5743,33913 & & \\
Tempo & 6 & 305,90667 & 50,98444 & $62,30^{\star \star}$ \\
Tratamentoxtempo & 18 & 38,10368 & 2,11687 & $2,58^{\star}$ \\
Residuo (b) & 24 & 19,63872 & 0,81828 & \\
\hline Total & 55 & 6106,98821 & & \\
\hline
\end{tabular}

${ }_{\star \star}^{*}$ significativo, ao nivel de $1 \%$ de significância; * significativo, ao nivel de $5 \%$ de significancia 
ANEXO A 4 Análise de variância dos teores de ácido ascórbico dos néctares dietéticos de goiaba, das variedade Pedro Sato, durante o período de armazenamento.

\begin{tabular}{llrrr} 
& & & \\
Causa de variação & G.L. & S.Q. & Q.M. & F \\
Tratamento & 3 & 4701,7386 & 1567,2462 & $1551,71^{\star \star \star}$ \\
Resíduo (a) & 4 & 3,3441 & 0,8360 & \\
Parcelas & 7 & 4705,0827 & 672,1546 & \\
Tempo & 6 & 286,9633 & 47,8272 & $43,35^{\star \star}$ \\
Tratamentoxtempo & 18 & 72,2086 & 4,0116 & $3,97^{\star \star}$ \\
Residuo (b) & 24 & 24,2402 & 1,0100 & \\
\hline Total & 55 & 5088,4947 & & \\
\hline
\end{tabular}

** significativo, ao nivel de $1 \%$ de significância

ANEXO B 1 Análise de variância dos teores de acidez total dos néctares comuns de golaba, da variedade Paluma, durante o periodo de armazenamento.

$\begin{array}{lllll}\text { Causa de variação } & \text { G.L. } & \text { S.Q. } & \text { Q.M. } & \text { F } \\ \text { Tratamento } & 3 & 0,086288 & 0,02876 & 2062,3784^{\star \star} \\ \text { Resíduo (a) } & 4 & 0,00005 & 0,00001 & \\ \text { Parcelas } & 7 & 0,08634 & 0,01233 & \\ \text { Tempo } & 6 & 0,01051 & 0,00175 & 231,4551^{\star \star} \\ \text { Tratamentoxtempo } & 18 & 0,00158 & 0,00008 & 11,6072^{\star \star} \\ \text { Resíduo (b) } & 24 & 0,00018 & 0,00001 & \\ \text { Total } & 55 & & & \end{array}$

** significativo, ao nivel de $1 \%$ de significáncia

ANEXO B 2 Análise de variância dos teores de acidez total dos néctares comuns de goiaba, da variedade Pedro Sato, durante o período de armazenamento.

\begin{tabular}{|c|c|c|c|c|}
\hline Causa de variação & G.L. & S.Q. & Q.M. & $F$ \\
\hline $\begin{array}{l}\text { Tratamento } \\
\text { Resíduo (a) }\end{array}$ & 3 & $\begin{array}{l}0,07532 \\
0,000008\end{array}$ & $\begin{array}{l}0,02510 \\
0,000002\end{array}$ & $5112,74^{\star \star}$ \\
\hline Parcelas & $\overline{7}$ & 0,07532 & 0,01076 & \\
\hline Tempo & 6 & 0,01081 & 0,00180 & $367,01^{\star \star}$ \\
\hline Tratamentoxtempo & 18 & 0,00174 & 0,00009 & $19,72^{\star \star}$ \\
\hline Resíduo (b) & 24 & 0,00011 & 0,000004 & \\
\hline Total & 55 & 0,08800 & & \\
\hline
\end{tabular}

** significativo, ao nivel de $1 \%$ de significância 
ANEXO B 3 Análise de variância dos teores de acidez total dos néctares dietéticos de goiaba, da variedade Paluma, durante o periodo de armazenamento.

\begin{tabular}{|c|c|c|c|c|}
\hline Causa de variação & G.L. & S.Q. & Q.M. & $F$ \\
\hline $\begin{array}{l}\text { Iratamento } \\
\text { Resíduo (a) }\end{array}$ & $\begin{array}{l}3 \\
4\end{array}$ & $\begin{array}{l}0,06515 \\
0,000006\end{array}$ & $\begin{array}{l}0,02171 \\
0,000001\end{array}$ & $13980,56^{\star \star}$ \\
\hline $\begin{array}{l}\text { Parcelas } \\
\text { Tempo } \\
\text { Tratamentoxtempo } \\
\text { Residuo (b) }\end{array}$ & $\begin{array}{l}7 \\
6 \\
18 \\
24\end{array}$ & $\begin{array}{l}0,06516 \\
0,01104 \\
0,00053 \\
0,00005\end{array}$ & $\begin{array}{l}0,00930 \\
0,00184 \\
0,00003 \\
0,000002\end{array}$ & $\begin{array}{r}770,88^{\star \star} \\
12,56^{\star \star}\end{array}$ \\
\hline Total & 55 & 0,07680 & & \\
\hline
\end{tabular}

$*$ significativo, ao nivel de $1 \%$ de significância

ANEXO B 4 Análise de variância dos teores de acidez total dos néctares dietéticos de goiaba, da variedade Pedro Sato, durante o período de armazenamento.

\begin{tabular}{lllll} 
Causa de variação & G.L. & S.Q. & Q.M. & F \\
Tratamento & 3 & 0,06387 & 0,02129 & $6021,75^{\star \star}$ \\
Resíduo (a) & 4 & 0,00001 & 0,000003 & \\
\hline Parcelas & 7 & 0,06388 & 0,00912 & \\
Tempo & 6 & 0,00947 & 0,00157 & $1269,62^{\star \star}$ \\
Tratamentoxtempo & 18 & 0,00065 & 0,00003 & $29,16^{\star \star}$ \\
Residuo (b) & 24 & 0,00002 & 0,000001 & \\
Total & 55 & 0,07404 & &
\end{tabular}

$\star \star$ significativo, ao nivel de $1 \%$ de significancia

ANEXO C 1 Análise de variância dos teores de sólidos solúveis dos néctares comuns de goiaba, da variedade Paluma, durante o período de armazenamento.

\begin{tabular}{|c|c|c|c|c|}
\hline Causa de variação & G.L. & $S . Q$. & Q.M. & $F$ \\
\hline $\begin{array}{l}\text { Tratamento } \\
\text { Residuo (a) }\end{array}$ & $\begin{array}{l}3 \\
4\end{array}$ & $\begin{array}{l}0,03910 \\
0,09214\end{array}$ & $\begin{array}{l}0,01303 \\
0,02303\end{array}$ & $0,76^{\text {ns }}$ \\
\hline $\begin{array}{l}\text { Parcelas } \\
\text { Tempo } \\
\text { Tratamentoxtempo } \\
\text { Resíduo (b) }\end{array}$ & $\begin{array}{l}7 \\
6 \\
18 \\
24\end{array}$ & $\begin{array}{l}0,13124 \\
0,19964 \\
0,14464 \\
0,41258\end{array}$ & $\begin{array}{l}0,01874 \\
0,03327 \\
0,00803 \\
0,00172\end{array}$ & $\begin{array}{l}1,34^{\text {ns }} \\
1,93^{\text {ns }}\end{array}$ \\
\hline
\end{tabular}

n.s. - não significativo, ao nivel de $5 \%$ de significáncia 
ANEXO C 2 Análise de variância dos teores de sólidos solúveis dos néctares comuns de goiaba, da variedade Pedro Sato, durante o período de armazenamento.

\begin{tabular}{llcccc} 
Causa de variação & G.L. & S.Q. & Q.M. & $F$ \\
\hline Tratamento & 3 & 0,04428 & 0,01476 & $0,44^{\text {ns }}$ \\
Residuo (a) & 4 & 0,07285 & 0,01821 & \\
Parcelas & 7 & 0,11713 & 0,01673 & \\
Tempo & 6 & 0,28857 & 0,04809 & $1,45^{\text {ns }}$ \\
Tratamentoxtempo & 18 & 0,40571 & 0,02253 & $0,68^{\text {ns }}$ \\
Residuo (b) & 24 & 0,79714 & 0,03321 & \\
\hline Total & 55 & 1,60857 & & \\
\hline
\end{tabular}

n.s. - năo significativo, ao nivel de $5 \%$ de significância

ANEXO C 3 Análise de variância dos teores de sólidos solúveis dos néctares dietéticos de goiaba, da variedade Paluma, durante o período de armazenamento.

\begin{tabular}{|c|c|c|c|c|}
\hline Causa de variação & G.L. & S.Q. & Q.M. & $F$ \\
\hline $\begin{array}{l}\text { Tratamento } \\
\text { Residuo (a) }\end{array}$ & $\begin{array}{l}3 \\
4\end{array}$ & $\begin{array}{l}0,01142 \\
0,04857\end{array}$ & $\begin{array}{l}0,00380 \\
0,01214\end{array}$ & $0,57^{\text {ns }}$ \\
\hline $\begin{array}{l}\text { Parcelas } \\
\text { Tempo } \\
\text { Tratamentoxtempo } \\
\text { Residuo (b) }\end{array}$ & $\begin{array}{l}7 \\
6 \\
18 \\
24\end{array}$ & $\begin{array}{l}0,05999 \\
0,06107 \\
0,10607 \\
0,16142\end{array}$ & $\begin{array}{l}0,00857 \\
0,01017 \\
0,00589 \\
0,00672\end{array}$ & $\begin{array}{l}1,51^{\text {ns }} \\
0,88^{\text {ns }}\end{array}$ \\
\hline Total & 55 & 0,38857 & & \\
\hline
\end{tabular}

n.s. - năo significativo, ao nivel de $5 \%$ de si g nificância

ANEXO C 4 Análise de variância dos teores de sólidos solúveis dos néctares dietéticos de goiaba, da variedade Pedro Sato, durante o período de armazenamento.

\begin{tabular}{|c|c|c|c|c|}
\hline Causa de variação & G.L. & S.Q. & Q.M. & $F$ \\
\hline $\begin{array}{l}\text { Tratamento } \\
\text { Resíduo (a) }\end{array}$ & $\begin{array}{l}3 \\
4\end{array}$ & $\begin{array}{l}0,00357 \\
0,02142\end{array}$ & $\begin{array}{l}0,00119 \\
0,00535\end{array}$ & $0,09^{n S}$ \\
\hline $\begin{array}{l}\text { Parcelas } \\
\text { Tempo } \\
\text { Tratamentoxtempo } \\
\text { Residuo (b) }\end{array}$ & $\begin{array}{l}7 \\
6 \\
18 \\
24\end{array}$ & $\begin{array}{l}0,02499 \\
0,17428 \\
0,271 \\
0,32857\end{array}$ & $\begin{array}{l}0,00357 \\
0,02904 \\
0,01507 \\
0,01369\end{array}$ & $\begin{array}{l}2,12^{\text {ns }} \\
1,10^{\text {ns }}\end{array}$ \\
\hline Total & 55 & 0,79928 & & \\
\hline
\end{tabular}

n.s. - nâo significativo, ao nivel de $5 \%$ de significância 
ANEXO D 1 Análise de variância dos valores de pH dos néctares comuns de goiaba, da variedade Paluma, durante o período de armazenamento.

\begin{tabular}{llllll} 
& & & \\
Causa de variação & G.L. & S.Q. & Q.M. & F \\
\hline Tratamento & 3 & 0,00052 & 0,00017 & $2,07^{\text {ns }}$ \\
Resíduo (a) & 4 & 0,00035 & 0,00008 & \\
Parcelas & 7 & 0,00087 & 0,00012 & \\
Tempo & 6 & 0,00104 & 0,00017 & $2,04^{\mathrm{ns}}$ \\
Tratamentoxtempo & 18 & 0,00237 & 0,00013 & $1,55^{\mathrm{ns}}$ \\
Resíduo (b) & 24 & 0,00204 & 0,00008 & \\
\hline Total & 55 & 0,00634 & &
\end{tabular}

n.s. - não significativo, ao nível de $5 \%$ de significåncia

ANEXO D 2 Análise de variância dos valores de pH dos néctares comuns de goiaba, da variedade Pedro Sato, durante o periodo de armazenamento.

$\begin{array}{llllll}\text { Causa de variação } & \text { G.L. } & \text { S.Q. } & \text { Q.M. } & \text { F } \\ \text { Tratamento } & 3 & 0,00007 & 0,00002 & 0,29^{\text {ns }} \\ \text { Resíduo (a) } & 4 & 0,00015 & 0,00003 & 0,00003 & \\ \text { Parcelas } & 7 & 0,00022 & 0,00002 & 0,33^{\text {ns }} \\ \text { Tempo } & 6 & 0,00016 & 0,00009 & 1,20^{\text {ns }} \\ \text { Tratamentoxtempo } & 18 & 0,00175 & 0,00008 & \\ \text { Resíduo (b) } & 24 & 0,00194 & & \end{array}$

O)

n.S. - näo significativo, ao nivel de $5 \%$ de significância

ANEXO D 3 Análise de variância dos valores de $\mathrm{pH}$ dos néctares dietéticos de goiaba, da variedade Paluma, durante o período de armazenamento.

\begin{tabular}{|c|c|c|c|c|}
\hline Causa de variação & G.L. & S.Q. & Q.M. & $F$ \\
\hline $\begin{array}{l}\text { Tratamento } \\
\text { Resíduo (a) }\end{array}$ & $\begin{array}{l}3 \\
4\end{array}$ & $\begin{array}{l}0,00017 \\
0,00037\end{array}$ & $\begin{array}{l}0,00005 \\
0,00009\end{array}$ & $1,66^{\text {ns }}$ \\
\hline $\begin{array}{l}\text { Parcelas } \\
\text { Tempo } \\
\text { Tratamentoxtempo } \\
\text { Resíduo (b) }\end{array}$ & $\begin{array}{l}7 \\
6 \\
18 \\
24 \\
\end{array}$ & $\begin{array}{l}0,00054 \\
0,00017 \\
0,00085 \\
0,00082\end{array}$ & $\begin{array}{l}0,00007 \\
0,00002 \\
0,00004 \\
0,00003\end{array}$ & $\begin{array}{l}0,84^{\text {ns }} \\
1,37^{\text {ns }}\end{array}$ \\
\hline Total & 55 & 0,00240 & & \\
\hline
\end{tabular}

n.s. - năo significativo, ao nivel de $5 \%$ de significancia 
ANEXO D 4 Análise de variância dos valores de $\mathrm{pH}$ dos néctares dietéticos de goiaba, da variedade Pedro Sato, durante o periodo de armazenamento.

\begin{tabular}{lllll} 
Causa de variação & G.L. & S.Q. & Q.M. & F \\
\hline Tratamento & 3 & 0,00004 & 0,00001 & $0,34^{\text {ns }}$ \\
Residuo (a) & 4 & 0,00042 & 0,00010 & \\
Parcelas & 7 & 0,00046 & 0,00006 & \\
Tempo & 6 & 0,00018 & 0,00003 & $0,66^{\text {ns }}$ \\
Tratamentoxtempo & 18 & 0,00091 & 0,00005 & $1,08^{\text {ns }}$ \\
Resíduo (b) & 24 & 0,00112 & 0,00004 & \\
Total & 55 & 0,00269 & &
\end{tabular}

n.s. - náo significativo, ao nivel de $5 \%$ de significancia

ANEXO E 1 Análise de variância dos valores de vácuo dos néctares comuns de goiaba, da variedade Paluma, durante o período de armazenamento.

$\begin{array}{lllll}\text { Causa de variação } & \text { G.L. } & \text { S.Q. } & \text { Q.M. } & \text { F } \\ \text { Tratamento } & 3 & 0,69053 & 0,23017 & 0,23^{\text {ns }} \\ \text { Resíduo (a) } & 4 & 0,45642 & 0,11410 & \\ \text { Parcelas } & 7 & 1,14695 & 0,16385 & \\ \text { Tempo } & 6 & 7,46714 & 1,24452 & 1,23^{\text {ns }} \\ \text { Tratamentoxtempo } & 18 & 8,02571 & 0,44587 & 0,44^{\text {ns }} \\ \text { Resíduo (b) } & 24 & 24,27857 & 1,011607 & \\ \text { Total } & 55 & 40,91839 & & \end{array}$

n.s. - năo significativo, ao nivel de $5 \%$ de significancia

ANEXO E 2 Análise de variância dos valores de vácuo dos néctares comuns de goiaba, da variedade Pedro Sato, durante o período de armazenamento.

\begin{tabular}{|c|c|c|c|c|}
\hline Causa de variação & G.L. & S.Q. & Q.M. & $F$ \\
\hline $\begin{array}{l}\text { Tratamento } \\
\text { Resíduo (a) }\end{array}$ & $\begin{array}{l}3 \\
4\end{array}$ & $\begin{array}{l}0,98339 \\
2,45642\end{array}$ & $\begin{array}{l}0,32779 \\
0,61410\end{array}$ & $0,76^{\text {ns }}$ \\
\hline $\begin{array}{l}\text { Parcelas } \\
\text { Tempo } \\
\text { Tratamentoxtempo } \\
\text { Resíduo (b) }\end{array}$ & $\begin{array}{l}7 \\
6 \\
18 \\
24\end{array}$ & $\begin{array}{r}3,43981 \\
1,75107 \\
12,42035 \\
10,32857\end{array}$ & $\begin{array}{l}0,49140 \\
0,29184 \\
0,69002 \\
0,43035\end{array}$ & $\begin{array}{l}0,68^{\text {ns }} \\
1,60^{\text {ns }}\end{array}$ \\
\hline Total & 55 & 27,93982 & & \\
\hline
\end{tabular}

n.s. - năo significativo, ao nivel de $5 \%$ de significancia 
ANEXO E 3 Análise de variância dos valores de vácuo dos néctares dietéticos de goiaba, da variedade Paluma, durante o período de amazenamento.

\begin{tabular}{|c|c|c|c|c|}
\hline Causa de variação & G.L. & S.Q. & Q.M. & $F$ \\
\hline $\begin{array}{l}\text { Tratamento } \\
\text { Residuo (a) }\end{array}$ & $\begin{array}{l}3 \\
4\end{array}$ & $\begin{array}{l}0,44428 \\
1,61571\end{array}$ & $\begin{array}{l}0,14809 \\
0,40392\end{array}$ & $0,23^{\text {ns }}$ \\
\hline $\begin{array}{l}\text { Parcelas } \\
\text { Tempo } \\
\text { Tratamentoxtempo } \\
\text { Residuo (b) }\end{array}$ & $\begin{array}{l}7 \\
6 \\
18 \\
24\end{array}$ & $\begin{array}{r}2,05999 \\
3,36428 \\
6,94571 \\
15,60428\end{array}$ & $\begin{array}{l}0,29428 \\
0,56071 \\
0,38587 \\
0,65017\end{array}$ & $\begin{array}{l}0,86^{\text {ns }} \\
0,59^{\text {ns }}\end{array}$ \\
\hline Total & 55 & 27,97428 & & \\
\hline
\end{tabular}

n.s. - não significativo, ao nivel de $5 \%$ de significáncia

ANEXO E 4 Análise de variância dos valores de vácuo dos néctares dietéticos de goiaba, da variedade Pedro Sato, durante o período de armazenamento.

\begin{tabular}{llllll} 
Causa de variação & G.L. & S.Q. & Q.M. & F & \\
Tratamento & 3 & 1,37285 & 0,45761 & $0,75^{\text {ns }}$ \\
Resíduo (a) & 4 & 6,93285 & 1,73321 & \\
Parcelas & 7 & 8,30570 & 1,18652 & \\
Tempo & 6 & 0,33928 & 0,05654 & $0,09^{\text {ns }}$ \\
Tratamentoxtempo & 18 & 10,37214 & 0,57623 & $0,95^{\text {ns }}$ \\
Residuo (b) & 24 & 14,61714 & 0,60904 & \\
Total & 55 & 33,63428 & & & \\
\hline
\end{tabular}

n.s. - não significativo, ao nivel de $5 \%$ de significância

ANEXO F 1 Análise de variância dos valores dos pesos brutos dos néctares comuns de goiaba, da variedade Paluma, durante o período de amazenamento.

\begin{tabular}{|c|c|c|c|c|}
\hline Causa de variação & G.L. & S.Q. & Q.M. & $F$ \\
\hline $\begin{array}{l}\text { Tratamento } \\
\text { Resíduo (a) }\end{array}$ & $\begin{array}{l}3 \\
4\end{array}$ & $\begin{array}{l}18,55403 \\
47,06195\end{array}$ & $\begin{array}{r}6,18467 \\
11,76548\end{array}$ & $0,91^{\text {ns }}$ \\
\hline $\begin{array}{l}\text { Parcelas } \\
\text { Tempo } \\
\text { Tratamentoxtempo } \\
\text { Resíduo (b) }\end{array}$ & $\begin{array}{l}7 \\
6 \\
18 \\
24\end{array}$ & $\begin{array}{c}65,61598 \\
63,98986 \\
87,19758 \\
162,8581\end{array}$ & $\begin{array}{r}9,37371 \\
10,66497 \\
4,84431 \\
6,78576\end{array}$ & $\begin{array}{l}1,57^{\text {ns }} \\
0,71^{\text {ns }}\end{array}$ \\
\hline Total & 55 & 379,66159 & & \\
\hline
\end{tabular}

n.s. - näo significativo, ao nivel de $5 \%$ de significáncia 
ANEXO F 2 Análise de variância dos valores dos pesos brutos dos néctares comuns de goiaba, da variedade Pedro Sato, durante o periodo de armazenamento.

\begin{tabular}{llrrr} 
Causa de variaçäo & G.L. & S.Q. & Q.M. & F \\
Tratamento & 3 & 9,96213 & 3,32071 & $0,41^{\text {ns }}$ \\
Residuo (a) & 4 & 46,97822 & 11,74455 & \\
Parcelas & 7 & 56,94035 & 8,13433 & \\
Tempo & 6 & 60,50057 & 10,08342 & $1,25^{\text {ns }}$ \\
Tratamentoxtempo & 18 & 51,39511 & 2,85528 & $0,35^{\text {ns }}$ \\
Residuo (b) & 24 & 193,12477 & 8,04687 & \\
\hline Total & 55 & 361,9682 & &
\end{tabular}

n.s. - năo significativo, ao nivel de $5 \%$ de significáncia

ANEXO F 3 Análise de variância dos valores dos pesos brutos dos néctares dietéticos de goiaba, da variedade Paluma, durante o período de armazenamento.

\begin{tabular}{|c|c|c|c|c|}
\hline Causa de variação & G.L. & S.Q. & Q.M. & $F$ \\
\hline $\begin{array}{l}\text { Tratamento } \\
\text { Residuo (a) }\end{array}$ & $\begin{array}{l}3 \\
4\end{array}$ & $\begin{array}{l}60,26664 \\
25,5021\end{array}$ & $\begin{array}{r}20,08881 \\
6,37552\end{array}$ & $2,51^{\text {ns }}$ \\
\hline $\begin{array}{l}\text { Parcelas } \\
\text { Tempo } \\
\text { Tratamentoxtempo } \\
\text { Residuo (b) }\end{array}$ & $\begin{array}{l}7 \\
6 \\
18 \\
24\end{array}$ & $\begin{array}{r}85,76874 \\
27,53846 \\
29,04153 \\
192,44700\end{array}$ & $\begin{array}{r}12,25267 \\
4,58974 \\
1,61341 \\
8,01863\end{array}$ & $\begin{array}{l}0,57^{\text {ns }} \\
0,20^{\text {ns }}\end{array}$ \\
\hline Total & 55 & 334,79574 & & \\
\hline
\end{tabular}

n.s. - năo significativo, ao nivel de $5 \%$ de significancia

ANEXO F 4 Análise de variância dos valores dos pesos brutos dos néctares dietéticos de goiaba, da variedade Pedro Sato, durante o período de armazenamento.

\begin{tabular}{|c|c|c|c|c|}
\hline Causa de variação & G.L. & S.Q. & Q.M. & $F$ \\
\hline $\begin{array}{l}\text { Tratamento } \\
\text { Resíduo (a) }\end{array}$ & $\begin{array}{l}3 \\
4\end{array}$ & $\begin{array}{r}6,05452 \\
21,83370\end{array}$ & $\begin{array}{l}2,01817 \\
5,45842\end{array}$ & $0,41^{n s}$ \\
\hline $\begin{array}{l}\text { Parcelas } \\
\text { Tempo } \\
\text { Tratamentoxtempo } \\
\text { Resíduo (b) }\end{array}$ & $\begin{array}{l}7 \\
6 \\
18 \\
24\end{array}$ & $\begin{array}{c}27,88822 \\
52,3392 \\
87,18614 \\
117,34490\end{array}$ & $\begin{array}{l}3,98403 \\
8,72320 \\
4,84369 \\
4,88937\end{array}$ & $\begin{array}{l}1,78^{\text {ns }} \\
0.99^{\text {ns }}\end{array}$ \\
\hline Total & 55 & 284,75849 & & \\
\hline
\end{tabular}

n.s. - náo significativo, ao nivel de $5 \%$ de significăncia 
ANEXO G 1 Análise de variância dos valores dos pesos líquidos dos néctares comuns de goiaba, da variedade Paluma, durante o período de armazenamento.

\begin{tabular}{|c|c|c|c|c|}
\hline Causa de variação & G.L. & S.Q. & Q.M. & $\mathrm{F}$ \\
\hline $\begin{array}{l}\text { Tratamento } \\
\text { Residuo (a) }\end{array}$ & $\begin{array}{l}3 \\
4\end{array}$ & $\begin{array}{r}1,89339 \\
61,13460\end{array}$ & $\begin{array}{r}0,63113 \\
15,28365\end{array}$ & $0,08^{\text {ns }}$ \\
\hline $\begin{array}{l}\text { Parcelas } \\
\text { Tempo } \\
\text { Tratamentoxtempo } \\
\text { Residuo (b) }\end{array}$ & $\begin{array}{l}7 \\
6 \\
18 \\
24\end{array}$ & $\begin{array}{r}63,02799 \\
96,29994 \\
114,05861 \\
198,53840\end{array}$ & $\begin{array}{r}9,00399 \\
16,04999 \\
6,33659 \\
8,77243\end{array}$ & $\begin{array}{l}1.94^{\text {ns }} \\
0,77^{\text {ns }}\end{array}$ \\
\hline
\end{tabular}

n.s. - năo significativo, ao nivel de $5 \%$ de significância

ANEXO G 2 Análise de variância dos valores dos pesos líquidos dos néctares comuns de goiaba, da variedade Pedro Sato, durante o período de armazenamento.

\begin{tabular}{|c|c|c|c|c|}
\hline Causa de variação & G.L. & S.Q. & Q.M. & $F$ \\
\hline Tratamento & 3 & 12,81692 & 4,27231 & $0,53^{\text {ns }}$ \\
\hline Resíduo (a) & 4 & 66,21467 & 16,55366 & \\
\hline Parcelas & 7 & 79,03159 & 11,29022 & \\
\hline Tempo & 6 & 64,72059 & 10,78676 & $1,33^{\text {ns }}$ \\
\hline Tratamentoxtempo & 18 & 81,87012 & 4,54834 & $0.56^{\text {ns }}$ \\
\hline Resíduo (b) & 24 & 195,28143 & 8,13673 & \\
\hline Total & 55 & 420,90374 & & \\
\hline
\end{tabular}

n.s. - nåo significativo, ao nivel de $5 \%$ de significância

ANEXO G 3 Análise de variância dos valores dos pesos líquidos dos néctares dietéticos de goiaba, da variedade Paluma, durante o período de armazenamento.

\begin{tabular}{|c|c|c|c|c|}
\hline Causa de variação & G.L. & S.Q. & Q.M. & $F$ \\
\hline $\begin{array}{l}\text { Tratamento } \\
\text { Residuo (a) }\end{array}$ & $\begin{array}{l}3 \\
4\end{array}$ & $\begin{array}{l}529,2762 \\
772,5033\end{array}$ & $\begin{array}{l}176,4254 \\
193,1258\end{array}$ & $1,03^{\text {ns }}$ \\
\hline $\begin{array}{l}\text { Parcelas } \\
\text { Tempo } \\
\text { Tratamentoxtempo } \\
\text { Residuo (b) }\end{array}$ & $\begin{array}{l}7 \\
6 \\
18 \\
24\end{array}$ & $\begin{array}{l}1301,77950 \\
1085,4271 \\
3475,0650 \\
4124,7149\end{array}$ & $\begin{array}{l}185,96850 \\
180,9045 \\
193,0592 \\
171,8631\end{array}$ & $\begin{array}{l}1,05^{\mathrm{ns}} \\
1,12^{\mathrm{ns}}\end{array}$ \\
\hline Total & 55 & 9986,9864 & & \\
\hline
\end{tabular}

n.s. - não significativo, ao nivel de $5 \%$ de significáncia 
ANEXO G 4 Análise de variância dos valores dos pesos líquidos dos néctares dietéticos de goiaba, da variedade Pedro Sato, durante o período de armazenamento.

\begin{tabular}{lllll} 
Causa de variação & G.L. & S.Q. & Q.M. & F \\
Tratamento & 3 & 5,30615 & 1,76872 & $0,28^{\text {ns }}$ \\
Residuo (a) & 4 & 34,71039 & 8,67760 & \\
Parcelas & 7 & 40,01654 & 5,71664 & \\
Tempo & 6 & 46,66802 & 7,77800 & $1,21^{\text {ns }}$ \\
Tratamentoxtempo & 18 & 100,18408 & 5,56578 & $0,87^{\text {ns }}$ \\
Residuo (b) & 24 & 153,83321 & 6,40972 & \\
\hline Total & 55 & 340,70185 & &
\end{tabular}

n.s. - nâo significativo, ao nivel de $5 \%$ de significáncia

ANEXO H 1 Análise de variância dos valores atribuídos ao sabor dos néctares comuns de goiaba, da variedade Paluma, durante o armazenamento.

\begin{tabular}{|c|c|c|c|c|}
\hline Causa de variacão & G.L. & S.Q. & Q.M. & $F$ \\
\hline Degustador & 7 & 7,9947917 & 1,1421131 & \\
\hline Tratamento & 3 & 36,6406250 & 12,2135417 & $60,25^{\star \star}$ \\
\hline Tempo & 2 & 13,2604167 & 6,6302083 & $32,71^{\star *}$ \\
\hline Tratamentoxtempo & 6 & 2,9062500 & 0,4843750 & $2,39^{\star}$ \\
\hline Resíduo & 173 & 35,0677083 & 0,2027035 & \\
\hline Total & 191 & 95,8697917 & & \\
\hline
\end{tabular}

ns-má significativo; ${ }^{* \star}=$ significativo ao nivel de $1 \% ;{ }^{\star}=$ significativo ao nivel de $5 \%$

ANEXO H 2 Análise de variância dos valores atribuídos ao sabor dos néctares comuns de goiaba, da variedade Pedro Sato, durante o armazenamento.

\begin{tabular}{|c|c|c|c|c|}
\hline Causa de variação & G.L. & S.Q. & Q.M. & $F$ \\
\hline Degustador & $7^{1}$ & 6,4531250 & 0,9218750 & \\
\hline Tratamento & 3 & 32,8072917 & 10,9357639 & $53,69^{\star \star}$ \\
\hline Tempo & 2 & 9,5937500 & 4,7968750 & $23,55^{\star \star}$ \\
\hline Tratamentoxtempo & 6 & 3,4895833 & 0,5815972 & $2,86^{\star \star}$ \\
\hline Residuo & 173 & 35,2343750 & 0,2036669 & \\
\hline Total & 191 & 87,5781250 & & \\
\hline
\end{tabular}

ANEXO H 3 Análise de variância dos valores atribuídos ao sabor dos néctares dietéticos de goiaba, da variedade Paluma, durante o armazenamento.

\begin{tabular}{llccc} 
Causa de variacão & G.L. & S.Q. & Q.M. & F \\
Degustador & 7 & 12,3958333 & 1,7708333 & \\
Tratamento & 3 & 79,4375000 & 26,4791667 & $165,20^{\star \star}$ \\
Tempo & 2 & 32,0416667 & 16,0208333 & $99,95^{\star \star}$ \\
Tratamentoxtempo & 6 & 4,8750000 & 0,8125000 & $5,07^{\star \star}$ \\
Residuo & 173 & 27,729167 & 0,160284 & \\
\hline Total & 191 & 156,479167 & &
\end{tabular}

ns= náo significativo; ${ }^{\star *}=$ significativo ao nivel de $1 \%$; ${ }^{\prime=}=$ significativo ao nivel de $5 \%$ 
ANEXO H 4 Análise de variância dos valores atribuídos ao sabor dos néctares dietéticos de goiaba, da variedade Pedro Sato, durante 0 armazenamento.

\begin{tabular}{|c|c|c|c|c|}
\hline Causa de variaçãó & GL & $S Q$ & Q.M & $F$ \\
\hline Degustador & 7 & 23,6458333 & 3,3779762 & \\
\hline Tratamento & 3 & 93,5625000 & 31,1875000 & $125,17^{\star \star}$ \\
\hline Tempo & 2 & 20,5729167 & 10,2864583 & $41,29^{\star \star}$ \\
\hline Tratamentoxtempo & 6 & 8,0937500 & 1,3489583 & $5,41^{* \star}$ \\
\hline Resíduo & 173 & 43,104167 & 0,249157 & \\
\hline Total & 191 & 188,979167 & & \\
\hline
\end{tabular}

$n \mathrm{~ns}=$ nzao significativo; $*=$ significativo ao nivel de $1 \%$; ${ }^{*}=$ significativo ao nivel de $5 \%$

ANEXO I 1 Análise de variância dos valores atribuídos à consistência dos néctares comuns de goiaba, da variedade Paluma, durante o armazenamento.

\begin{tabular}{|c|c|c|c|c|}
\hline Causa de variação & G.L. & $S . Q$. & Q.M. & $F$ \\
\hline Degustador & 7 & 6,28645833 & 0,89806548 & \\
\hline Tratamento & 3 & 1,97395833 & 0,65798611 & $2,91^{*}$ \\
\hline Tempo & 2 & 1,54166667 & 0,77083333 & $3,41^{*}$ \\
\hline Tratamentoxtempo & 6 & 0,54166667 & 0,09027778 & $0,40^{\text {ns }}$ \\
\hline Resíduo & 173 & 39,1510417 & 0,2263066 & \\
\hline Total & 191 & 49,4947917 & & \\
\hline
\end{tabular}

ANEXO I 2 Análise de variância dos valores atribuídos à consistência dos néctares comuns de goiaba, da variedade Pedro Sato, durante o armazenamento.

\begin{tabular}{|c|c|c|c|c|}
\hline Causa de variação & G.L. & S.Q. & Q.M. & $F$ \\
\hline Degustador & 7 & 6,16666667 & 0,88095238 & \\
\hline Tratamento & 3 & 2,29166667 & 0,76388889 & $6,31^{* \star}$ \\
\hline Tempo & 2 & 1,15625000 & 0,57812500 & $4,77^{\star \star}$ \\
\hline Tratamentoxtempo & 6 & 0,67708333 & 0,11284722 & $0,93^{\text {ns }}$ \\
\hline Resíduo & 173 & 20,9583333 & 0,1211464 & \\
\hline
\end{tabular}

Total $191 \quad 31,2500000$

ns=-măo significativo; **=significativo ao nivel de $1 \%$; ${ }^{*}=$ significativo ao nivel de $5 \%$

ANEXO I 3 Análise de variância dos valores atribuídos à consistência dos néctares dietéticos de goiaba, da variedade Paluma, durante o armazenamento.

\begin{tabular}{|c|c|c|c|c|}
\hline Causa de variaçẫo & G.L. & S.Q. & Q.M. & $F$ \\
\hline Degustador & 7 & 33,6197917 & 4,8028274 & \\
\hline Tratamento & 3 & 4,8072917 & 1,6024306 & $10,15^{\star \star}$ \\
\hline Tempo & 2 & 1,1354167 & 0,5677083 & $3,60^{*}$ \\
\hline Tratamentoxtempo & 6 & 1,6145833 & 0,2690972 & $1,70^{\text {ns }}$ \\
\hline Resíduo & 173 & 27,3177083 & 0,1579058 & \\
\hline Total & 191 & 68,4947917 & & \\
\hline
\end{tabular}


ANEXO I 4 Análise de variância dos valores atribuidos à consistência dos néctares dietéticos de goiaba, da variedade Pedro Sato, durante 0 armazenamento.

\begin{tabular}{|c|c|c|c|c|}
\hline Causa de variação & G.L. & S.Q. & Q.M. & $F$ \\
\hline Degustador & 7 & 40,0364583 & 5,7194940 & \\
\hline Tratamento & 3 & 7,9322917 & 2,6440972 & $11,50^{\star \star}$ \\
\hline Tempo & 2 & 12,1979167 & 6,0989583 & $26,53^{\star \star}$ \\
\hline $\begin{array}{l}\text { Tratamentoxtempo } \\
\text { Resíduo }\end{array}$ & $\begin{array}{l}6 \\
173\end{array}$ & $\begin{array}{r}5,8020833 \\
39,7760417\end{array}$ & $\begin{array}{l}0,9670139 \\
0,2299193\end{array}$ & $4,21 \star \star$ \\
\hline Total & 191 & $10 \overline{, 7447917}$ & & \\
\hline
\end{tabular}

ns $=$ nå significativo; ${ }^{* \star}=$ significativo ao nivel de $1 \% ; "=$ significativo ao nivel de $5 \%$

ANEXO J 1 Análise de variância dos valores atribuídos à cor dos néctares comuns de goiaba, da variedade Paluma, durante o armazenamento.

\begin{tabular}{|c|c|c|c|c|}
\hline Causa de variação & G.L. & S.Q. & Q.M. & $F$ \\
\hline Degustador & 7 & 2404,83333 & 343,54762 & \\
\hline Tratamento & 3 & 3794,50000 & 1264,83333 & $19,66^{\star \star \star}$ \\
\hline Tempo & 2 & 2613,09375 & 1306,54687 & $20,31^{\text {** }}$ \\
\hline Tratamentoxtempo & 6 & 361,28125 & 60,21354 & $0,94^{\text {ns }}$ \\
\hline Resíduo & 173 & 11130,29167 & 64,33695 & \\
\hline Total & 191 & 20304,00000 & & \\
\hline
\end{tabular}

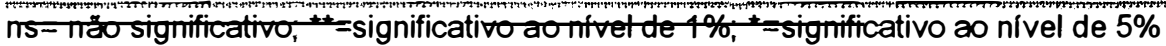

ANEXO J 2 Análise de variância dos valores atribuidos à cor dos néctares comuns de goiaba, da variedade Pedro Sato, durante o armazenamento.

\begin{tabular}{|c|c|c|c|c|}
\hline Causa de variação & G.L. & S.Q. & Q.M. & $F$ \\
\hline Degustador & 7 & 3,89583333 & 0,55654762 & \\
\hline Tratamento & 3 & 6,02083333 & 2,00694444 & $11,03^{\text {** }}$ \\
\hline Tempo & 2 & 5,54166667 & 2,77083333 & $15,23^{\star \star}$ \\
\hline Tratamentoxtempo & 6 & 4,54166667 & 0,75694444 & $4,16^{\star \star}$ \\
\hline Resíduo & 173 & 31,4791667 & 0,1819605 & \\
\hline Total & 191 & 51,4791667 & & \\
\hline
\end{tabular}

ns= nåo significativo; ${ }^{\star \star}=$ significativo ao nivel de $1 \%$; ${ }^{\star *}=$ significativo ao nível de $5 \%$

ANEXO J 3 Análise de variância dos valores atribuídos à cor dos néctares dietéticos de goiaba, da variedade Paluma, durante o armazenamento.

\begin{tabular}{|c|c|c|c|c|}
\hline Causa de variação & G.L. & S.Q. & Q.M. & $\mathrm{F}$ \\
\hline Degustador & 7 & 10,5364583 & 1,5052083 & \\
\hline Tratamento & 3 & 5,1822917 & 1,7274306 & $10,16^{\star \star}$ \\
\hline Tempo & 2 & 13,7916667 & 6,8958333 & $40,58^{\star \star}$ \\
\hline Tratamentoxtempo & 6 & 3,8333333 & 0,6388889 & $3,76^{\star \star}$ \\
\hline Resíduo & 173 & 29,4010417 & 0,1699482 & \\
\hline Total & 191 & 62,7447917 & & \\
\hline
\end{tabular}


ANEXO J 4 Análise de variância dos valores atribuídos à cor dos néctares dietéticos de goiaba, da variedade Pedro Sato, durante o armazenamento.

\begin{tabular}{|c|c|c|c|c|}
\hline Causa de variaçâo & G.L. & S.Q. & Q.M. & $F$ \\
\hline Degustador & 7 & 52397668 & 7485381 & \\
\hline Tratamento & 3 & 196606532 & 65535511 & $40,41^{\star \star}$ \\
\hline Tempo & 2 & 161227814 & 80613907 & $49,71^{\star \star}$ \\
\hline Tratamentoxtempo & 6 & 56641450 & 9440242 & $5,82^{\star \star}$ \\
\hline Resíduo & 173 & 280552525 & 1621691 & \\
\hline Total & 191 & 747425990 & & \\
\hline
\end{tabular}

ns= $=$ năo significativo; ${ }^{* *}=$ significativo ao nível de $1 \% ; "$ significativo ao nível de $5 \%$ 


\section{REFERÊNCIAS BIBLIOGRÁFICAS}

ALMEIDA, P. G. Conservação química dos refrigerantes. Engarrafador Moderno. v.5, n.38, p. 60-65, mar./abr. 1995.

ALMEIDA, P. G. Edulcorantes a opção diet. Engarrafador Moderno. v.7, n.46. p.5763, jul/ago. 1996a.

ALMEIDA, P. G. O uso de acidulantes e conservantes em bebidas. Engarrafador Moderno. v.7, n.47, p. 41-48, set./out. 1996b.

ALVES, R. M. V.; GARCIA, E. E. C. Embalagem para sucos de frutas. Coletånea ITAL. v.23, n. 2, p. 105-122, jul./dez. 1993.

ANGELUCCI, E. Menos calorias para os polióis: 2,4kcal/g. Alimentos e Tecnologia. v.9, n.47, p.48-49,1993.

ANTUNES, A. J.; CANHOS, V. P. Aditivos em Alimentos. São Paulo: Secretaria da Indústria, Comércio, Ciência e Tecnologia. 1982. 178p.

ANTUNES, L. A. F.;OLIVEIRA, J. S. O emprego dos sorbatos em alimentos. Higiene Alimentar. v.2, n.4, p. 174-180, dez. 1983.

ARAÚJO, J. M. A. Conservadores químicos em alimentos. Boletim Sociedade Brasileira de Ciência e Tecnologia de Alimentos. v.24, n.3/4, p. 192-210, jul./dez. 1990. 
AROEIRA, J.S. Fruticultura Geral I Parte. Viçosa. Universidade Rural do Estado de Minas Gerais, Escola Superior de Agricultura, 1960. 125p.

ASKAR, A.; EL-ASHWAH, F. A.; OMRAN, H. T.; LABIB, A. A. S. Color stability of tropical nectars and a simple method of its determination. Fruit Processing. V. 4, n. 1, p.14-20, jan. 1994.

ASKAR, A.; EL-SAMAHY, S.; IBRAHIM, S.; EL-EMARY, Z., H. Reduction of eavy metal content and improving quality of canned mango nectar. Fruit Processing. v. 3, n. 3, p. 84-92, mar. 1993.

ASKAR, A.; GHONAIM, S. M.; ABDEL-FADEEL, M. G.; ALI, A. M.; ABD EL-GAIED, I. O. Quality assurance of peach pulp and nectar. Fruit Processing. n.6, v.4, p. 151-155. abr. 1996.

BADIFU, G. I. O. Effect of long term storage of processed Nigeria grown edible leavy green vegetables on vitamin C content. Journal Agricutural Food Chemistry, Nigeria. v.39 p.538-541, 1991.

BARAMANRAY, A; GUPTA, O. P.; DHAWAN, S. S. Evaluation of guava (Psidium guajava) hybrids for making nectar. Haryana Journal of Horticultural Sciences. v. 24, n. 2, p. 102-109. abr./jun. 1995.

BERNIZ, P. J. Avaliação industrial de variedades de manga (Mangifera indica L.) para a elaboração de néctar. Viçosa, 1984. 57p. Tese (M.S.).

BELL, T. A.; ETCHELLS, J. L.; BORG, A. F. Influence of sorbic acid on the growth of certain species of bacteria, yeasts and filamentous fung. Journal Bacteriol. v.77, p. 573-580, 1959.

BLOCK, G.; LANGSETH, L. Antioxidant vitamins and disease prevention. Food Technology. v.48, n.7, p.80-84. 1994. 
BOBBIO, F. O; BOBBIO, P. A Introdução a química de alimentos. $2^{2}$ ed. Campinas: Varela, 1989. 222p.

BORSCHIVER, S.; BOMTEMPO, J. V., ANTUNES, A. S. O mercado de aditivos para alimentos: Tendéncia quanto ao uso dos diferentes tipos. Engenharia de Alimentos. São Paulo, v.4, n.20, p.22-26,jul/ago, 1998.

BRANEN, A. L. Introduction to food additives. In:BRANEN, A L.; DAVISON, P. M.; SALMINEN, S. Food Additives. New York, Marcel Dekker, Inc., 1990. cap.1, p.1-8.

BRASIL. Ministério da Saúde. Comissão Nacional de Normas e Padrões para Alimentos. Resolução $n^{\circ} 04 / 88$ do Decreto Lei $n^{\circ}$ 55.871/65. In: ASSOCIAÇÃO BRASILEIRA DAS INDÚSTRIAS DE ALIMENTOS. Compêndio da Legislação de Alimentos. rev. 4 São Paulo: ABIA, 1988. v. 1A, p. 350.

BRASIL. Ministério da Saúde. Secretaria de Vigilância Sanitária de Alimentos. Portaria n. 540 de outubro de 1997. In: Associação Brasileira das Indústrias de Alimentação. Compêndio da legislação de alimentos. São Paulo: ABIA, 1997. Anexo.

BRASIL. Portaria $n^{\circ} 41$, de 12 de maio de1995. Aprova as normas técnicas referentes a alimentos para fins especiais. Diário Oficial [da República Federativa do Brasil], Brasilia, v.133, n.91, p.6886-6887, 15 maio. 1995a. Seção 1.

BRASIL. Portaria $n^{\circ} 122$, de 24 de novembro de1995. Aprova as normas técnicas referentes a alimentos para fins especiais. Diário Oficial [da República Federativa do Brasil], Brasília, v.133, n.229, p.19788-19790, 30 nov. 1995b. Seção 1. 
CÂNDIDO, L. M. B.; CAMPOS, A. M. Alimentos para fins especiais: Dietéticos. São Paulo, Varela. 1996. 423p.

CARAGY, A. B. Cancer - Preventive foods and ingredients. Food Technology. v.46, n.4, p. 65-67. 1994.

CARVALHO, V.D. Qualidade e conservação pós-colheita de goiabas. Informe Agropecuário. Minas Gerais. v. 7. n.179, p.48-54. 1994.

CEREDA, E. ; SAMPAIO, C. E. Influência da temperatura e da agitação no teor de vitamina C no suco de maracujá. In: Jomada Cientifica da Faculdade de Ciências Medicas e Biológicas de Botucatu, 2, Botucatu, 1970. Anais...Botucatu, Associação dos docentes da F.C.M.B.B., 1970. p.130.

CEREDA, M. P.; GOLDONI, J. S.; CAGLIARI, A. M. Variação do teor de ácido ascórbico em suco integral durante o armazenamento pelo frio. II. Maracujá. Alimentação. n.58, p. 24-30, jan./fev. 1982.

CHITARRA, M.I.F.; CHITARRA, A.B. Pós-colheita de frutos e hortaliças: fisiologia e manuseio. Lavras: Faepe, 1990. 293p.

COUNSELL, J. N.; HORNIG, P. H. Vitamina C (Ascorbic Acid). London: Apllied Science Publishers Londos, 1981. 450p.

DAREZZO, H. M.; DURIGAN, J.F. Armazenamento refrigerado de goiaba "Paluma", colhida em diferentes estádios de maturação. Unesp.- Jaboticabal. 1995. 30p. (não publicado).

DAVIDSON, P. M.; JUNEJA, V. K. Antimicrobial agents. In:BRANEN, A L.; DAVISON, P. M.; SALMINEN, S. Food Additives. New York: Marcel Dekker, Inc., 1990. cap.4, p.83-138. 
DAWSON, R. H. Sensory testing guide for panel evaluation of food and beverages. Food and Technology, v.8, n.18, p. 25-31, 1964.

DE MARTIN, Z. Industrialização da goiaba. Alimentos e Bebidas. v.5 ,n. 1, p. 12-18. 1969.

DE MARTIN, Z.; TEIXEIRA, C. G.; BLEINROTH, E. W.; ANGELUCCI, E.; PUPO, L. M.; TOSELLO, Y. Processamento de purê e néctar de mamão pasteurizados. Coletånea do Instituto de Tecnologia de Alimentos. v.4, p. 155-176. $1971 / 72$.

DESHPANDE, S. S.; SALUNKE, D. K.; DESHPANDE, U. S. Food acidulants. In: MAGA, J. A; TU, A T. Food Addtive Toxicology. New York: Marcel Dekker, Inc., 1995. cap.2. p.11-87.

DIAS, J. M. M. Estudo da produção e dos atributos físicos e químicos dos frutos de duas variedades de goiabeira (Psidium guajava L.) submetidas a quatro épocas de poda, em Virtude do Rio Branco, Minas Gerais. Viçosa, 1983. 68p. (Tese M.S.).

DIWAKAR CHATTERGIE, UMESH P. SINGH, RAM KUMAR. A note on the bearing of guava. Maryana Journal of Horticultural Science, India, v.21, n1/2, p.69-71, 1993.

DJANIKIAN, P.; BIONDO, O.; BELEIA, A. Estabilidade de ácido ascórbico em sucos de maracujá, acerola e suas combinações, não pasteurizados, armazenados a $4^{\circ} \mathrm{C}$. Arquivos de Biologia e Tecnologia. v.39, n.2, p. 239-245, jun. 1996.

DUPAIGNE, P. Sur la détermination du percentage de jus dans les fruits frais. Fruits. v. 26, n. 4 , p.305-308, 1971. 
ELEUTÉRIO, R. M. C. Variação do teor de ácido ascórbico e de $\beta$-caroteno em suco e geléia de acerola (Malpighia glaba L. - sinônimo M. punicifolia L.) durante o armazenamento. Piracicaba, 1998. 77p. Dissertação (M.S.) - Esalq.

ESTEVES, M. T. da C.; CARVALHO, V. D. de; CHITARRA, M. I. F.; CHITARRA, A. B.; PAULA, M. B. de Caracterização dos frutos de seis cultivares de goiabeiras (Psidium guajava L.) na Maturação. I - Determinações físicas e químicas. In: Anais. VII Congresso Brasileiro de Fruticultura. Florianópolis. v.2, 1984a. 720p.

ESTEVES, M. T. da C.; CARVALHO, V. D. de; CHITARRA, M. I. F.; CHITARRA, A. B.; PAULA, M. B. de Caracterização dos frutos de seis cultivares de goiabeiras (Psidium guajava L.) na Maturação. II - Vitamina C e Taninos. In: Anais. VII Congresso Brasileiro de Fruticultura. Florianópolis. v.2, 1984b. 720p.

FALCONE, M.; PIEPKE, W. Sorbato de potássio como preservativo de suco de abacaxi. AB.Tecnologia de Alimentos e Bebidas., v.1, n.12, p.24-33, 1964

FIGUEIREDO, I. B.; UZELAC, M. Aroma em alimentos, In: FIGUEIREDO, I. B.; UZELAC, M. Aroma em alimentos. Campinas: ITAL, 1976. (Instruções Técnicas, n.9).

FIORAVANÇO, J. C.; PAIVA, M. C.; MANICA, I. Goiaba : aspectos qualitativos. Cadernos de Horticultura UFGRS. v.3, n.3, 12p. 1995.

FONSECA, H.; NOGUEIRA, J. N. Conteúdo de ácido ascórbico em produtos industrializados de goiaba (Psidium guayava). Aquivos Brasileiros de Nutrição. n. 1 e 2, v. 24, p.135-139. jan./dez. 1968.

FONSECA, H.; NOGUEIRA, J. N. Processamento e conservação de alimentos de origem vegetal - frutas. In: CAMARGO, R. (coord.) Tecnologia de Produtos Agropecuários - Alimentos. São Paulo: Nobel, 1984. cap.7. p.113-135.

FRANCO, G. Nutrição: texto básico e tabela de composição química dos alimentos. 6 ed. Rio de Janeiro: Ateneu, 1992. 
FRANCO, G. Tabela de composição química dos alimentos. 2 ed. São Paulo: Ateneu, 1994. p.53-58: Ácido ascórbico.

GARCIA, J. L. M. Matéria-prima. In: MEDINA, J. C. et al. Goiaba - Da cultura ao processamento e comercialização. Campinas, ITAL, 1978. cap.2. p. 48-57. (Série Frutas Tropicais, 6).

GAVA, A. J. Os diabéticos, as bebidas de baixa caloria e o açúcar: $O$ que fazer ? Ponto de vista do fabricante de refrigerantes. Alimentação. n.83, p.10-14, maio/agosto, 1986.

GAVA, A. J. Processamento asséptico de sucos de frutas. Alimentação. n.76, p.3237, jan.ffev., 1985.

GIESE, J. H. Alternative sweetemers and bulking agents. Food Tecnology. v.47, n.1, p.114-125, jan. 1993.

GIRARDOT, N. F.; PERYAM, D. R.; SHARPIRO, L. Selection of sensory testing panels. Food and Technology, v.4, n.6, p. 140-143, 1952.

GONZAGA NETO, L. Goiaba para exportação: aspéctos técnicos da produção. Brasilia: Embrapa-SPI, 1994. 49p. (Série Publicações Técnicas FRUPEX, 5)

GRAUMLICH, T. R.; MARCY, J. E.; ADAMS, J. P. Asseptically package orange juice and concentrate: a review of the influence of processing and packaging conditions on quality. Journal of Agriculture and food chemistry. Washington, v. 34. n. 3. p. $402-405,1986$.

HALPERN, A.; BRICARELLO, S.; OLIVA, A. B. G.; GOUVEIA, M. L. Adoçantes artificiais. Revista Brasileira de Clínica Terapautica. São Paulo, v.10, n.5, p.174-187, 1991. 
HANSEN, J. D.; APPLEMAN, M. D. The effect of sorbic, propionic and caproic acids on the growth of certain clostridia. Ed Res. n.20, p.92-96, 1955.

HOCKING, A. D.; PITT, J. I. Food spoilage fungi. II Heat - resistant fungi. CSIRO Food Res. Quart. , v.44, n.4, p. 73-82, 1984.

JAGTIANI, J.; CHAN, H. T.; SAKAI, W. Tropical Fruit Processing. London: Academic Press, 1988, 240p.

JACKIX, M. H. Doces, geléias e frutas em calda. São Paulo: İcone, 1988.172p.

KALRA, S. K.; TANDON, D. K. Guava nectars from sulphited pulp and their blends whit mango nectar. Indian Food Packer. v. 38, n. 1, p. 74-77, jan./fev. 1984.

KANESIRO, M. A. B.; FALEIROS, R. R. S.; SARTORI, J. L.; MELO, W. J.; PIZAURO JR. J. M.; BANZATTO, D. A. Efeito de niveis de $N$ e $P$ sobre algumas características químicas de frutos do tomateiro colhidos em diferentes estágios de maturação. Científica, v. 10, n.2, p.233, 1982.

KATO, K.; DE MARTIN, Z. J. Processamento: produtos, caracterização e utilização. In: MEDINA, J. C. (coord.) Goiaba - Da cultura ao processamento e comercialização. Campinas: ITAL, 1978. cap. 3. p.61-79. (Série Frutas Tropicais, $6)$.

KAVATI, R. Cultivares. In: Anais. I Simpósio brasileiro sobre a cultura da goiabeira. Jaboticabal, abril. 184p. 1997.

LEITÃO, M. F. F.; DELAZARI, I.; EIROA, M.N.U.; ARIMA, H. K. Avaliação de sucos, refrigerantes, refrescos, néctares e xaropes em face dos padrões microbiológicos brasileiros. Boletim do Instituto de Tecnologia de Alimentos. n. 49, p. 75-91, jan./fev. 1977.

LEMES, C. A. A onda diet. Revista Saúde. São Paulo, v.7, n.9, p.16-29,1990. 
LEMOS, G. C. das; JUNIOR, J. C. de O; COLLIER, L.S.; CARVALHO, A. J. C. de; MANICA, I. Goiaba : Amadurecimento, colheita, classificação, embalagem, transporte e armazenamento. Cadernos de Horticultura. v.3, n.4, 8 p. 1995.

LIMA, M. A.; DURIGAN, L. F.; TOSTES, D. R. D. Avaliação do comportamento respiratório de goiabas "Pedro Sato" e a influência de diferentes embalagens na sua conservação sob refrigeração. XVI Congresso Brasileiro de Ciências e tecnologia de alimentos. julho, 1998, SBCTA, Rio de Janeiro. 4p.

LIMA, U. A. Agroindustrialização de Frutas. São Paulo. Fealq. 1998. 151p.

LORENÇO, E., J. Aroma em função da adição de ácido ascórbico.

LYNCH, L. J.; CHANG, A. T.; LUM, J. C.; SHERMAN, G. D.; SEALE, P. E. Hawaii Food Processors Handbook of Fruits, Vegetable, Meats and Fish. Hawaii Agricultural Experiments Station, Circular n. 55, 30p., 1959.

MAHAN, L. K.; ARLIN, M. T. Krause: Alimentos, nutrição e dietoterapia. São Paulo. Roca, 1995. 975p.

MARTELETO, L. T. Estudo da produção e dos atributos fisicos e quimicaos de dez variedades de goiabas (Psidium guajava L.), em Visconde do Rio Branco, Minas Gerais, visando o consumo ao natural e à industrialização. Viçosa, 1980. 63p. Dissertação (M.S.)-Universidade Federal de Viçosa.

MARTIN, S. L. Selection and training of sensory judges. Food and Technology, v.11, n.27, p. 22-26, 1973.

MEDINA, J. C. Cultura. In: MEDINA, J. C. (coord.) Goiaba - Da cultura ao processamento e comercialização. Campinas: ITAL, 1978. cap.1. p.5-45. (Série Frutas Tropicais, 6). 
MENEZES, S.; VIEGAS, E. Dietéticos em alta. Alimentos \& Tecnologia. São Paulo. v.6, n.32, p.22-26. 1990.

MONEGO, E. T.; PEIXOTO, M. R. G.; JARDIM, P. C. V.; SOUZA, A. L. L. Alimentos dietéticos: Uma visão prática. Revista de Nutrição. PUCCAMP, Campinas, v.7, n.1, p.9-31, jan/jun., 1994.

MONTGOMERY, M. W. Processamento de purês e sucos de frutas năo citricas. Campinas Fundação Tropical de Pesquisa e Tecnologia "Andre Tosello", 1988.

MORAES, M. A. C. Métodos para avaliação sensorial dos alimentos, Campinas: Ed. Unicamp, 1985. 85p.

MOSTAFA, G. A.; ABD EL-HADY, E. A.; ASKAR, A. Preparation of papaya and mango nectar blends. Fruit Processing. n.7,v.5, p. 180-185. 1997.

NABORS, O. L.; GELARDI, R. C. Alternative Sweeteners. New York, Marcel Dekker, 1991. 461p.

NASCIMENTO, L. M.; SANTOS, R. R.; RIBEIRO, I. J. et al. Caracterização físicoquímica dos frutos de 22 cultivares de giabeiras (Pisidium guajava L.) durante proceso de maturação. I. Coloração da casca, textura sólidos solúveis totais, acidez total titulável e pH. Revista Brasileira de Fruticultura. v.13, n.3, p.35-42. 1991.

NOVAES, L. C. Avaliação da qualidade das variedades de morango Guarani e Oso Grande, para a obtenção de néctares. Piracicaba, 1997. 119p. Tese (M.S.).

OKOLI, E. C.; EZENWEKE, L. O. Formulation and shelf-life of a bottled papaya juice beverage. International Journal of Food Science and Technology. v. 25, n. 6 , p. 706-710, dez. 1990. 
OLIVA, P. B.; MENEZES, H. C.; FERREIRA, V. L. P. Estudo da estabilidade do néctar de acerola. Ciência e Tecnologia de Alimentos ou SBCTA. v.16, n.3, p. 228232, out./dez. 1996.

O MERCADO DIET, Alimentos \& Tecnologia. São Paulo. v.6, n.32, p.26-27 1990.

PASSOS, L. P.; PINHEIRO, R. V. R.; CASALI, V. W. D.; STRINGHETA, P. C.; CONDÉ, A. R. Competição entre dez variedades de goiaba (Psidium guajava L.) em Visconde do Rio Branco, Minas gerais. Revista Ceres, Viçosa, v.26, n.147, p.417-433. 1979.

PAVANELLO J. F. O uso de aditivos em alimentos. Alimentos e Bebidas. v.1, n.7, p.22-24, 1990.

PEREIRA, F. M. Cultura da Goiabeira. UNESP, Jaboticabal, 55p. 1995

PEREIRA, F. M. Rica e Paluma: Novas cultivares de goiabeira - Comunicação técnica. In: Anais. VII Congresso Brasileiro de Fruticultura. Florianópolis. V.2, 720p. 1984.

PEREIRA, F. M.; MARTINEZ JÚNIOR, H. Goiabas para industrialização. Jaboticabal, UNESP. 142P. 1986.

PINHEIRO, R. V. R.; MARTELETO, L. O.; SOUZA, A. C. G. de; CASALI, V. W. D.; CONDÉ, A. R. Produtividade e qualidade dos frutos de dez variedades de goiaba, em Visconde do Rio Branco, Minas Gerais, visando ao consumo ao natural e à industrialização. Revista Ceres. v.31, n.177, 360-387p. 1984.

RAMANA, K. V. R.; RAMASWAMY, H. S.; ARAVINDA-PRASAD, B.; PATWARDHAN, M. V.; RANGANNA, S. Journal of Food Science and Technology, India. V.21, n. 5, p.282-285. 1984. 
RANGANNA, S. Manual of analysis of fruit and vegetable products. New York: Mc Graw-Hill,1977. 634p.

RICHARDS, N. S. P. S. Avaliação da qualidade das variedades Chandler e Reiko para a obtenção de morango em calda. Piracicaba, 1996. 90p. Dissertação (M.S.)

ROCHA, I. C. Suco de Acerola: Efeito da temperatura de pasteurização e armazenamento. Recife, 62 p. Dissertação (Mestrado em Ciências e Tecnologia de Alimentos). Universidade Federal de Pernambuco, 1988.

RODRIGUES, C. Diet e light. Alimentos \& Tecnologia. São Paulo. v.9, n.58, p. 5560. 1995.

SALOMÓN, E. A. G.; DE MARTIN, Z. J.; KATO, K.; SILVA, S. D.; MORI, E. E.M.; BLEINROTH, E. W. Formulação de néctares de frutas tropicais. Boletim do Instituto de Tecnologia de Alimentos. n.50, p. 103-121, mar./abr. 1977.

SANCHES-NIEVA, F. Extration, processing, canning and keeping quality of acerola juice. Journal of Agricultural of University of Puerto Rico. v. 9, p. 375-380. 1955.

SHEWINM, E. R. Antioxidants. In:BRANEN, A L.; DAVISON, P. M.; SALMINEN, S. Food Additives. New York, Marcel Dekker, Inc., 1990. cap.5, p.139-194.

SHIROSE, I. Estatística aplicada à experimentação organoléptica, Campinas: Instituto de Tecnologia de Alimentos, 1985. p. 96-111.

SORBITOL: a natureza presente. GETEC, Indústria Guanabara S.A. 1997. 3p. Boletim informativo.

SOUZA FILHO, M. S. M.; FONSECA, J. L. F.; SARMENTO, S. G. R. Processamento e estabilidade do xarope de cajú (Anacardium occidentale, L.) Boletim do Centro de Pesquisa e Processamento de Alimentos. v.10, n.1, p. 53-58, jan.jun. 1992. 
TAVARES, L. O complemento alimentar. Alimentos e Tecnologia. v.6, n.32, p.3638. 1990.

TRESSLER, D. K.; JOSLYN, M. A. Fruits and vegetable juice processing technology. Chicago: AVI. Westport, 1961. 1028p.

UBOLDIEIROA, M. N. Microrganismos deteriorantes de sucos de frutas e medidas de controle. Boletim Sociedade Brasileira de Ciência e Tecnologia de Alimentos. v.23, n.3/4, p.141-160, jul./dez. 1989.

UBOLDI EIROA, M. N.; LEITÃO, M. F. F.; DAVENPORT, R. R.; CULLEN, B T. Zygosaccharomyces baillii em sucos de frutas concentrados: estudo da ocorrência e avaliação da sua resistência ao calor e aos conservantes químicos. Coletânea do ITAL. vol. 14, p.57-72. 1984.

VALENTINI, C. Refresco saudável. Veja. v.32, n.4, p.70, 27 jan. 1999.

VEGRO, C. L. R.; MIRANDA, M. C. Estrutura e dinâmica do mercado de goiaba e derivados. Informações Econômicas. SP, v.24, n.8, p.15-26, ago. 1994.

VIEIRA, R.; WOOLFE, M.; PIRES, E. et al. Produção de suco concentrado de cajú. Ciência e Tecnologia de Alimentos, Campinas. v.2, n.2, p.222-232, 1982.

VOLPI, E. D. Aditivos alimentares. Alimentação e Nutrição. V.6, n.23, p. 40-44, 1985.

WILSON, C. W.; SWAW, P. E.; CAMPHELL, C. W. Determination of organic acids and sugar in guava (Psidium guajava L.) cutivars by high-performanece liquid chromatography. Journal Science Food Agricultual. n.33, v. 8, p.77-780. 1982.

WINTON, A. L.; WINTON, K. B. Análise de alimentos. Barcelona: Hispano Americano, 1958.1205p.

ZAMBÃO, J. C.; Bellintani NETO, A. M.. Cultura da goiaba. Bol. Téc. CATI. n.236, março, 1998. 23p. 